\title{
Some Differences in Corporate Structure in Germany, Japan, and the United States
}

Mark J. Roe ${ }^{\dagger}$

\author{
CONTENTS
}

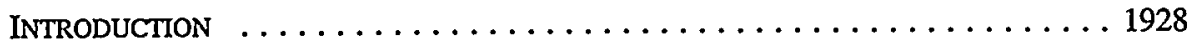

I. THE Classical Economic Model of THE Public FIRM $\ldots \ldots \ldots \ldots 1933$

II. German AND JAPANESE INFLUENCE THROUGH STOCKHOLDING:

SHARED CONTROL AND A FlatTER AUTHORITY STRUCTURE $\ldots \ldots \ldots \ldots 1936$

A. Large Firms and Large Voting Blocks . . . . . . . . . . . 1936

B. Structured Interaction ....................... 1941

C. Size of Foreign Financial Intermediaries . . . . . . . . . . . 1946

D. American Banking Regulation . . . . . . . . . . . . . 1948

1. German Universal Banks in the United States? . . . . . . . . 1949

2. Japanese Main Banks in the United States? ............ 1951

3. Main Banks and Universal Banks-The Potential for Control . . . 1954

4. Main Banks and Universal Banks-The Suppression and

Capture of the Securities Market . . . . . . . . . . . 1955

E. Other Regulatory Impediments . . . . . . . . . . . . 1956

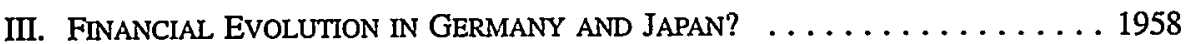

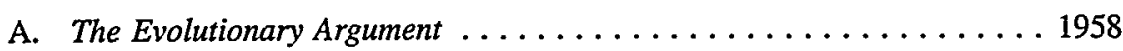

B. Problems with the Evolutionary Argument . . . . . . . . . . . . . 1959

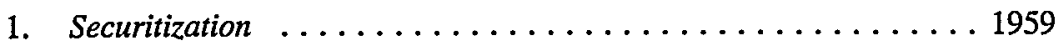

2. Autonomy . . . . . . . . . . . . . . . . . 1962

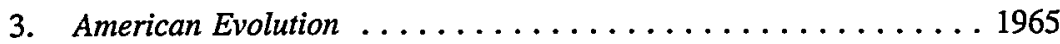

$\dagger$ Professor, Columbia Law School. Theodor Baums, Bernard Black, Victor Brudney, Ronald Gilson, Victor Goldberg, Jeffrey Gordon, Robert Hamilton, Hideki Kanda, Klaus Hopt, Lou Lowenstein, Steve Kaplan, Fritz Kübler, Gerald Neuman, Hugh Patrick, J. Mark Ramseyer, Detlev Vagts, and Paul Windolf made useful comments. Douglas Cardwell, Stacy Cooper, Marco Geromin, Burkard Gopfert, Megumiko Ishida, Steven Lorenz, Martina Stoldt, Hans-Gert Vogel, and Jean-Claude Zerey assembled data, research, and translations of German and Japanese materials. The Bradley Foundation supported this research. 
4. Economic Evolution and the Cost of Capital ......... 1966

IV. Political Evolution IN Germany ANd JaPAN? . . . . . . . . . . . 1967

A. German "Populism" . . . . . . . . . . . . . . . . . . . . . . . 1967

B. Japanese Interest Groups . . . . . . . . . . . . . . . . . . . . 1972

V. SHAREd Authority: WeAKNESSES ANd Strengths . . . . . . . . . . . . . 1977

A. Problems with Management . . . . . . . . . . . . . . . . . . . . . 1979

1. Increasing Accountability . . . . . . . . . . . . . . . . 1979

2. Monitoring by Multiple Intermediaries . . . . . . . . . . 1980

a. Multiple Blocks Checking Each Other . . . . . . . . . 1981

b. Multiple Blocks Impelling Action . . . . . . . . . . . 1981

c. Multiple Blocks and Power Sharing . . . . . . . . . . . 1982

3. Monitoring the Banks . . . . . . . . . . . . . . . . 1983

4. Personifying Shareholders ... . . . . . . . . . . . . 1984

5. Improving Decisions . . . . . . . . . . . . . . . . . . . 1985

B. Problems with Financial Markets: Institutions as the Problem . . . . . 1987

1. Enhancing the Information Flow . . . . . . . . . . 1987

2. Improving Loan Markets . . . . . . . . . . . . . . . . . 1987

C. Problems in Large-Scale Industry: Organization . . . . . . . . . . . 1988

VI. IMPLICATIONS FOR AMERICAN STRUCTURE . . . . . . . . . . . . . . . . . . . . . 1989

A. Germany and Japan as Blueprint? . . . . . . . . . . . . . 1990

B. Path Dependence and the Futility of Legal Change? . . . . . . . . . 1992

C. The Paradox of International Competition: Solution and Problem . . . 1994

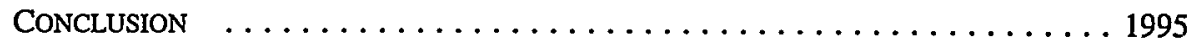

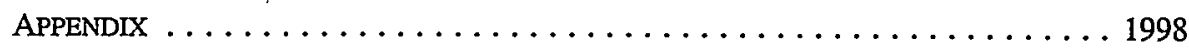

\section{INTRODUCTION}

Ownership of the large public corporation in Germany and Japan differs markedly from that in the United States. Here, senior managers hold the reins of power; scattered individuals and institutions own the stock. American financial intermediaries only recently have begun to project power into corporate boardrooms; they have historically been dispersed, weak, and uninterested. In the German and Japanese large firm, in contrast, senior managers must share power with active intermediaries wielding the votes of large blocks of stock. 
These differences and the different law, history, and politics that helped produce them cast doubt on current thinking about the origin of the large American public firm. True, firms had to tap vast pools of capital to reach economies of scale and, as shareholders diversified, scattered ownership shifted power to managers. While this is the dominant economic paradigm, it omits a critical step: American shareholders could have diversified through powerful intermediaries, but they did not. Corporate functions could have become further specialized, with strong intermediaries sharing governance functions with managers, but they did not. Had such intermediaries developed in the United States, a flatter structure of shared power could have developed in the large American firm, as it did in Germany and Japan. Elsewhere I have argued that one must look beyond economics to explain the American results: America's politics of financial fragmentation, rooted in federalism, populism, and interest group pressures, pulverized American financial institutions, contributing heavily to the rise of the Berle-Means corporation. ${ }^{1}$

In Part I of this Article, I argue that even a brief comparison of corporate ownership structures between Germany and Japan on the one hand, and the United States on the other, poses problems for prevailing academic theories. The classical economic explanation for the public firm emphasizes scale economies, shareholder diversification, and the divergence of managerial goals from stockholder goals. The economic explanation would, if it were universal, tend to predict that nations with similar economies would have similar corporate structures. There is a best way to make steel, and presumably there is a best way to organize large steel firms. Thus, managerial incentive compensation schemes, proxy fights, conglomerates, takeovers, and boards of independent outsiders, all of which reduce (or reflect) the costs of organizing the large, American public firm, should play a role in corporate governance in all three nations. At a minimum, the absence of these features in the flatter, shared authority structure prevalent in Germany and Japan poses a challenge, because it shows that there is more than one way to deal with the large firm's organizational problems. And the differences in corporate structure suggest that differing political histories, cultures, and paths of economic development must be added to the economic model to explain the differing structures. The economic model must be down-sized and considered to be the special case that arises if intermediaries are fragmented.

The classical economic model does not account for the German and Japanese corporate structure, whose basic features I present in Part II. Large financial intermediaries, usually banks, hold concentrated blocks of stock in many foreign firms, including the very largest. Bankers and managers interact

1. Mark J. Roe, A Political Theory of American Corporate Finance, 91 CoLUM. L. REv. 10 (1991) [hereinafter Roe, Political Theory]; Mark J. Roe, Political and Legal Restraints on Ownership and Control of Public Companies, 27 J. FIN. ECON. 7 (1990). 
in structured settings, where power has been shared between firms and financiers, unlike in the United States, where the chief executive officer has historically controlled the firm from the top of a hierarchy, without significant accountability to financial intermediaries.

Comparison allows us to test the hypothesis that law and the politics that underlie it help determine corporate structure. If U.S. firms could readily adopt the German or Japanese structure under U.S. law, we would have a partial contradiction of the law and politics hypothesis. In fact, several laws bar U.S. banks from involvement in the governance of American firms. Most critically, the foreign banks have a national reach that would violate the McFadden Act; they are relatively much larger than U.S. banks, giving them the size needed to control large slices of large firms' capital structure. The Bank Holding Company Act of 1956, as usually interpreted, requires U.S. banks to be passive, but the foreign banks are not passive. The Glass-Steagall Act limits American banks' securities business.

German national banks enter boardrooms by combining votes from stock they own directly, stock in bank-controlled investment companies, and securities they vote for their brokerage customers. Combining banks, mutual funds, and brokers in this way would violate the McFadden Act, the GlassSteagall Act, and the Bank Holding Company Act. Japanese banks are also active in corporate governance through truly national banks and, even though Japan has a Glass-Steagall Act (imposed by America after World War II) to separate commercial banks from investment banks, Japanese regulators effectively repealed it by forcing savings and corporate financing into Japanese banks.

These laws, necessary to fully understanding the American public firm, have been the San Andreas fault line in American corporate governance, historically severing America's largest financial institutions from its largest industrial firms. While we'll never know whether American-style fragmentation would have developed in the absence of legal roadblocks, American law would have been sufficient to block both German- and Japanese-style financial institutions from developing here.

In Part III, I examine whether the differences in corporate structure are only temporary because financial institutions in Germany and Japan are "behind" America and evolving without political pressure to resemble American institutions. There are contrary trends abroad-some point toward less concentration and less institutional voice, some point to more voice or to stability. And there are weak trends toward greater concentration and institutional voice here in the United States. The mixed facts indicate financial evolution is uneven; we are evolving to look (a little) like them and they are evolving to look (a little) like us.

Even if foreign financial institutions clearly were fragmenting and American institutions were concentrating, doubts about current corporate 
theories would persist. Foreign politics could have induced the foreign evolution. In Part IV, we see that today's foreign structures depend partly on the path they took from the foreign statist past, which militated toward financial concentration. Today political forces not all that different from those in America's past are weakening the intermediaries. In Germany, persistent popular pressure has led to Parliamentary proposals to reduce the power of banks over industrial stock. In Japan, efforts to transform credit-based financial power, which is weakening, to stock-based boardroom power, have not been fully successful yet, because the laws left by the post-World War II American occupation preclude such a transformation, and interest group conflict-mostly between bankers and brokers-tends to support the status quo. To transform their financial system, the Japanese must dismantle the American framework. They are beginning to do so, but they may fail.

In Part V, I analyze the common elements in the German and Japanese structural patterns and compare them to the U.S. structure in order to find theoretical explanations for their survival despite their obvious weaknesses. Institutional ownership discourages entrepreneurial leadership, risks conflicts of interest, and may make adaption to change more difficult. Moreover, agency problems may simply shift from the firm to the intermediary. Although a simple inquiry might try to find the better corporate structure and anoint it the preferred candidate, complications afflict such an inquiry. First, there isn't much evidence that the foreign structures contribute greatly to better performance. Second, a legal inquiry differs from an economic one. As long as institutional engagement in corporate governance advantages some firms, we have reason to regret some of our restrictions. Finding some value in the foreign structures, however, does not mean we should require them here; absent spillover effects, we should only allow firms that want them to adopt them. Third, even if we came to regret our restrictions, we might not necessarily demand their repeal or predict that their repeal would lead to rapid restructuring, because the path-dependent development of American financial institutions and corporate structures impedes change. Fourth, it might turn out that neither the American fragmentation nor foreign concentration is optimal, or it might turn out that any foreign successes are culturally dependent or embedded in institutions (like labor relations or the regulatory system) that are impossible to import. The comparative inquiry may just show that there are more possibilities than the American one. Fifth, product market competition in an internationalized economy is the best self-corrective. Whatever the source of the recent success of foreign firms-and I suspect corporate structure is tertiary-competition induces American firms to perform better.

What are the possible foreign strengths? Although a corporate law academic's first inquiry would likely be to see if the German and Japanese corporate structure controls managerial agency costs well, the competitive advantage of the foreign structure may lie not just in reducing what we think 
of as agency costs, but in (1) changing the environment of decisionmaking-bringing more individuals and organizations to the table when technologies and markets are changing too rapidly for a single CEO or a single firm to stay current; (2) improving the information flow to large stockholders in ways that a fragmented securities market cannot achieve; or (3) improving organizational performance by facilitating relation-specific investments without using a stultifying, large vertical organization and by providing a matrix for decisionmaking across related organizations. Even if future research shows none of these hypotheses about Germany and Japan to be true, or shows that the advantages of the true hypotheses are offset by their disadvantages, the study of the differences in corporate structure is worthwhile because it illustrates that the current American arrangements are not inevitable, but instead are highly dependent on the organization of financial intermediaries. We may never want to import foreign features, but once we see that corporate structure is variable, we may be more willing to reexamine our own system.

In Part VI, we see that in reexamining our system, we should not allow Germany and Japan to become blueprints for American financial institutions. The organization of banks is too important to be driven by debatable corporate governance concerns. Nor is it clear that legal change would induce structural change. The gains, if any, from change may be small and might fail to exceed the transaction costs of any change. Complex institutions are shaped by their own history, including their regulatory history; legal permission may not lead institutions to take the newly-opened opportunities, at least not immediately. Moreover, CEO's are embedded in several markets and organizational features beyond corporate governance relations with institutional shareholders. These other markets and organizational features may be strong enough to render any gains from corporate change small.

Finally, I conclude this review of corporate structures with a simple claim: How a nation organizes its financial institutions deeply determines its large firm corporate ownership structure. In America, a deep gap separates finance and industry; in Germany and Japan such a fault line does not yet fully separate intermediaries from managers. Neither ownership fragmentation due to scale economies nor the economic model can explain enough of the structural differences. Corporate ownership structure is highly sensitive to the organization of financial intermediaries, which in turn is highly sensitive to popular attitudes toward financial concentration and political fights. 


\section{The Classical Economic Model of THE Public Firm}

Since Adolf Berle and Gardiner Means published The Modern Corporation and Private Property ${ }^{2}$ in 1932, American corporate law academics' central task has been to understand the separation of ownership from control in the large American corporation. In the standard story, the rise of large-scale production technologies at the end of the nineteenth century demanded huge inputs of capital that could only be raised from far-flung investors who, demanding diversification and liquidity, were only able to buy small pieces of a firm's equity. Small holders distant from the enterprise lacked the information, skill, and incentive to monitor managers, who became relatively free from shareholder oversight.

This unwieldy structure yielded agency costs, described in the modern reformulation as the sum of (1) bonding costs, as managers tried to assure that they would do a good job; (2) monitoring costs, as shareholders tried to oversee managers; and (3) a residual loss that could not be eliminated. ${ }^{3}$ Corporate law scholarship sought to understand these costs, to explain features of the firm as either aligning managers' interests with those of shareholders or as the residuum of unavoidable loss, and to recommend ways to further reduce these costs. In equilibrium, there would be no further costs to eliminate. Any observed costs would be either the bonding or monitoring costs, whose elimination would cost more in increased residual loss, or the residual loss, whose elimination would cost more in offsetting bonding or monitoring costs.

Corporate academics sought to perfect the independent director, who is not beholden to management. Other means to minimize agency costs have included managerial labor markets, incentive compensation tied to stock price, capital markets that denied bad managers access to capital, and high debt that heightened fear of bankruptcy. Conglomerates in their ideal form centralized information and checked managers; ${ }^{4}$ in their pathological form, they built empires. In contractarian corporate thought, corporate law was a contract to minimize agency costs. State corporate law provided a standard form for most firms and allowed the remaining ones to tailor the contract to their specific situations. $^{5}$ Finally, some financial theorists explained shareholder powerlessness as efficient; stockholders should not influence firm decisions because their specialty was bearing risk, not decisionmaking. ${ }^{6}$

2. Adolf Berle \& Gardiner Means, The Modern Corporation and Private Property (1932).

3. The 1970's state-of-the-art was Michael C. Jensen \& William H. Meckling, Theory of the Firm: Managerial Behavior, Agency Costs and Ownership Structure, 3 J. FIN. ECON. 305, 308 (1976).

4. OLIVER E. WILLIAMSON, MARKETS AND HIERARCHIES: ANALYSIS AND ANTITRUST IMPLICATTONS 155-75 (1975).

5. Frank H. Easterbrook \& Daniel R. Fischel, The Economic Structure of Corporate Law 34-35 (1991).

6. Eugene F. Fama, Agency Problems and the Theory of the Firm, 88 J. POL. ECON. 288 (1980). 
By the 1980's, however, agency theorists were unsure whether America had achieved a long-run equilibrium in corporate structure in which the further reduction of agency costs had become unimportant. Many scholars argued that takeovers cured large, residual agency costs because managers who deviated too much from shareholders' interests risked a hostile takeover. Skeptics viewed some takeovers as resulting from the agency costs of errant managers expanding their empires, but others argued that even these costs would be eliminated in another wave of takeovers that would break up the empires. ${ }^{7}$ Regardless of whether takeovers cured or exacerbated agency problems, many corporate law scholars viewed agency cost explanations as central to understanding the American corporation. ${ }^{8}$

Our classical economic model would imply that large firms in every economy would face similar problems. The organization of large-scale industry in the United States generated agency problems and solutions; large-scale industry elsewhere should tend to develop the same organization, problems, and solutions. As foreign industry "caught up" with American industry, economies of scale would require huge inputs of capital from far-flung investors who would let power shift to managers, leading to a similar fragmented ownership, afflicted with similar managerial agency costs. The alternatives to this prediction might be too horrible for corporate law scholars to imagine. Corporate structure might not matter. Or, different governance systems might yield different advantages and disadvantages, making it difficult for one system to dominate the other. Or, each system might be efficient in its own national context, indicating that there are several equally efficient ways to organize large-scale industry. Or, the U.S. governance system may have arisen and survived because U.S. laws and politics suppressed the obvious alternatives to the Berle-Means corporation.

The differences in corporate structure seem to contradict the classical economic model, at least in its most simple form. Elsewhere I have advanced an additional hypothesis to explain the development of the large public firm in America. ${ }^{9}$ There is more than one way to move savings from households to industry. A securities market that produces fragmented ownership is only one way, and it is the prevailing way in America. But, funds could also move

7. Bernard S. Black, Bidder Overpayment in Takeovers, 41 STAN. L. REV. 597, 627-28 (1989).

8. For overviews of the agency theory literature, see Michael C. Jensen \& Clifford W. Smith, Stockholder, Manager, and Creditor Interests: Applications of Agency Theory, in RECENT ADVANCES IN CORPORATE FINANCE 93 (Edward I. Altman \& Marti G. Subrahmanyam eds., 1985) and Clifford W. Smith, Agency Costs, in THE NEW PALGRAVE: FinANCE (John Eatwell et al. eds., 1989).

9. Roe, Political Theory, supra note 1. For related discussions, see WILLIAM G. OUCHI, THE M-FORM SOCIETY: HOW AMERICA CAN RECAPTURE THE COMPETTTIVE EDGE 82-90 (1984); LESTER C. THUROW, THE Zero SUM SOLUTION 164-65 (1985); Bernard S. Black, Shareholder Passivity Reexamined, 89 Mich. L. REv. 520 (1990); Ronald J. Gilson \& Reinier H. Kraakman, Reinventing the Outside Director: An Agenda for Institutional Investors, 43 STAN. L. REV. 863 (1991); Joseph A. Grundfest, Subordination of American Capital, 27 J. Fin. ECON. 89 (1990); Michael C. Jensen, Eclipse of the Public Corporation, HARV. BuS. REV., Sept.-Oct. 1989, at 61 . 
from households to firms through large, powerful financial intermediaries that control big blocks of stock in industry while providing their investors with diversification and liquidity. Such powerful institutional intermediaries are more important abroad than in America. Quite a bit of evidence indicates that American politics deliberately fragmented financial institutions, their portfolios, and their ability to aggregate stock into influential voting blocks. Thus, we may hypothesize that if American political history had taken a different path, financial intermediaries might have played a different role in the American economy, and the structure of authority in the large public firm might also be different.

We cannot go back to 1890 and re-run American history without the politics of financial fragmentation to see whether American financial intermediaries and firms develop differently. We can, however, search abroad for different foreign governance structures and see whether the differences correlate with differences in financial regulation. In fact, the history of foreign financial regulation differs from the American experience, supporting the hypothesis that the politics of financial intermediation is a key determinant of corporate structure. The economic model cannot alone explain foreign structures and their differences with the American structures; it needs a political theory of American corporate finance to provide an adequate explanation.

The contractarian version of the classical economic says corporate law is a standard contract that shareholders and managers would adopt if they could cheaply bargain over their relationship with the firm; or, in its normative form, the contractarian version asserts that corporate law should conform to the contract that parties would tend to negotiate. By focusing on state corporate law, particularly Delaware corporate law and the ordering among shareholders, boards of directors, and managers, we American corporate law scholars have overlooked key laws that limit financial intermediaries' ability to control large blocks of stock and to become involved in corporate governance. To co-opt the political critique, proponents of the contractarian model must concede that important mandatory rules are found, perhaps not in state corporate law, but in the rules dictating the organization of financial intermediaries and their relationship with large firms. They can then energize the normative form of the economic model and criticize mandatory rules if the rules bar useful contracts.

The foreign differences thus cast doubt on the standard American evolutionary paradigm - that corporate ownership mediated through securities markets is the highest form of financial development, successfully providing ownership, diversification, and liquidity in just the right proportions. If we believed that financial fragmentation is economically (as opposed to politically) inevitable then the economic model could survive as the sole explanation for corporate structures. But the persistence thus far of differences in foreign ownership structures suggests not only that more that one evolutionary path 
exists, but also that the recent increase in American institutional investors' corporate governance activity is probably the delayed result of our historical suppression of strong intermediaries.

The point here is not to displace the part of the economic model that explains the role of technology, economies of scale, and far-flung investors. Rather, the goal is to displace the next step in the model's reasoning-that these features must give rise to fragmented ownership, with distant shareholders and powerful managers. The classical economic model can stand, but only if down-sized to a local equilibrium arising when financial institutions are fragmented. If a nation does not fragment its financial institutions, or if a nation designs other means of corporate governance-by privileging labor, or managers, or one financial institution or another, for example-then different organizational structures may emerge. How a nation regulates capital's deployment will affect how firms are organized. The history of American financial fragmentation, the foreign systems, and the modest contemporary concentration of American institutional ownership all indicate not only that there is more than one way to move capital into large firms, but also that the American-style public corporation is more a local custom than the result of an inevitable economic evolution.

\section{GERMAN AND JAPANESE INFLUENCE THROUGH STOCKHOLdING: SHARED CONTROL AND A FLATTER AUTHORITY STRUCTURE}

Differences in the ownership of large firms in Germany and Japan, on the one hand, and those in the United States, on the other, are startling. Stock in large German and Japanese firms is held in big voting blocks; frequently a handful of institutional shareholders votes $20 \%$ of a firm's stock. In America, in contrast, even after the concentration and institutionalization of recent years, the largest five shareholders rarely together control as much as $5 \%$ of a large firm's stock. Despite significant legal differences between Germany and Japan, both nations have ownership structures that provide for a sharing of power so that no person or institution has complete control. The U.S. structure of corporate ownership focuses power in management, especially in the chief executive officer.

\section{A. Large Firms and Large Voting Blocks}

In both Germany and Japan, but not in America, the typical large firm's stock is held in concentrated voting blocks. CEO's of the ten largest German firms usually face two or three big institutional blocks, each controlling $10 \%$ of the vote; CEO's of the ten largest American firms face no such big institutional blocks. CEO's at many large German companies face a small group of institutional voting blocks that controls nearly half of the stock voted; 
the equivalent figure in the United States is only $5 \%$. Table I presents the voting blocks for typical large German firms; Table II presents GM's ownership structure, which is typical for the large American firm, ${ }^{10}$ as well as the voting structures for the largest automakers in Germany and Japan.

\section{TABLE I. Aggregate Voting Blocks of Largest Three German Banks (1986)"}

\begin{tabular}{||lccccc||}
\hline \hline $\begin{array}{l}\text { Rank and Name } \\
\text { of Company }\end{array}$ & $\begin{array}{c}\text { Percent of } \\
\text { Shares } \\
\text { Voted at } \\
\text { Meeting }\end{array}$ & $\begin{array}{c}\text { Percent of } \\
\text { Shares } \\
\text { Held by } \\
\text { Deutsche } \\
\text { Bank }\end{array}$ & $\begin{array}{c}\text { Percent of } \\
\text { Shares } \\
\text { Held by } \\
\text { Dresdner } \\
\text { Bank }\end{array}$ & $\begin{array}{c}\text { Percent of } \\
\text { Shares } \\
\text { Held by } \\
\text { Commerz } \\
\text { bank }\end{array}$ & $\begin{array}{c}\text { Total Percent } \\
\text { of Shares } \\
\text { Held by } \\
\text { Three Largest } \\
\text { Banks }\end{array}$ \\
\hline 1. Siemens & 60.64 & 17.64 & 10.74 & 4.14 & 32.52 \\
2. Daimler-Benz & 81.02 & 41.80 & 18.78 & 1.07 & 61.66 \\
3. Volkswagen & 50.13 & 2.94 & 3.70 & 1.33 & 7.98 \\
4. Bayer & 53.18 & 30.82 & 16.91 & 6.77 & 54.50 \\
5. BASF & 55.40 & 28.07 & 17.43 & 6.18 & 51.68 \\
6. Hoechst & 57.73 & 14.79 & 16.92 & 31.60 & 63.48 \\
9. VEBA & 50.24 & 19.99 & 23.08 & 5.85 & 48.92 \\
\hline
\end{tabular}

10. Table XIII shows similar structures for other large American firms. For a complete breakdown of institutional ownership for the largest 10 American firms, see Carolyn Kay Brancato et al., Institutional Investor Concentration of Economic Power: A Study of Institutional Holdings and Voting Authority in U.S. Publicly Held Corporations app. 2 (Sept. 12,1991) (unpublished study, on file with author).

11. Source: Amo Gottschalk, Der Stimmrechtseinfluss der Banken in den Aktionärsversammlungen der Grossunternehmen, 5 WSI-MITTEILUNGEN 294, 298 (1988). Although Gottschalk's data-from 1986-is not current, it is the most recent data available. This table combines the German banks' votes from brokerage stock, directly-owned stock, and, apparently, mutual fund stock. 
TABLE II. Top Five Institutional Voting Blocks in GM, Daimler-Benz, and Toyota ${ }^{12}$

\begin{tabular}{|c|c|c|c|c|c|}
\hline \multicolumn{2}{|c|}{ Daimler-Benz } & \multicolumn{2}{|l|}{ Toyota } & \multicolumn{2}{|c|}{ General Motors } \\
\hline $\begin{array}{l}\text { Institutional } \\
\text { Manager }\end{array}$ & $\begin{array}{c}\text { Percent of } \\
\text { Shares }\end{array}$ & $\begin{array}{l}\text { Institutional } \\
\text { Manager }\end{array}$ & $\begin{array}{c}\text { Percent of } \\
\text { Shares }\end{array}$ & $\begin{array}{l}\text { Institutional } \\
\text { Manager }\end{array}$ & $\begin{array}{c}\text { Percent of } \\
\text { Shares }\end{array}$ \\
\hline Deutsche Bank & 41.80 & Sakura Bank & 4.9 & Mich. St. Treas. & 1.42 \\
\hline Dresdner Bank & 18.78 & Sanwa Bank & 4.9 & Bernstein Stanford & 1.28 \\
\hline Commerzbank & 12.24 & Tokai Bank & 4.9 & Wells Fargo & 1.20 \\
\hline Sonst. Kredit & 4.41 & Nippon Life & 3.8 & CREF & 0.96 \\
\hline Bayerische L-Bank & 1.16 & Long-Term Cred. Bk. & 3.1 & Bankers Trust NY & 0.88 \\
\hline Top 5 Shareholders & 78.39 & & 21.6 & & 5.74 \\
\hline Top 25 Shareholders & N.A. & & N.A. & & 13.93 \\
\hline
\end{tabular}

German bankers' voting power comes from direct ownership of stock, from control over investment companies, and, most importantly, from authority to vote stock that the bank's brokerage customers own but deposit with the bank. Although the German banks do not own a large amount of stock directly for their own benefit, when they deploy their capital in stock ownership, they deploy it in big blocks. As Table VIII in the Appendix shows, in the one hundred largest German industrial enterprises, banks directly own for their own accounts twenty-two blocks of at least 5\% of the outstanding stock. Banks also vote the small one or two percent blocks owned by bank-sponsored investment companies. ${ }^{13}$ Finally, banks vote the brokerage stock they hold as custodian. Typically, individual investors deposit the stock they own with their bank, and, unless the owner gives the bank special instructions, the bank votes the custodial shares. German banks often hold as custodian and vote more than $10 \%$ of the stock of a large company. ${ }^{14}$

How does the ability to vote large blocks of stock, some of which the bank owns for itself and most of which it holds as custodian, allow the bank to

12. Source: CDA Investment Technologies, 13(f) Institutional Portfolios, Spectrum Institutional Portfolios (database for year-end 1990 GM data, assembled by Riverside Economic Associates); Gottschalk, supra 11, at 298 (data for Daimler-Benz' voting blocks at 1986 shareholders' meeting); JAPAN COMPANY HANDBOOK 790 (Tōyō Keizai Inc., 1992) (data for Toyota's voting blocks). The GM and Toyota data are typical for the very largest American and Japanese firms. Daimler-Benz' largest vote holder is atypically large, due to Deutsche Banks' atypically large block of stock that it owns for the bank's own account. The Daimler-Benz data is based on votes actually cast at the 1986 shareholders' meeting; GM and Toyota data are based on stock owned with full voting authority, irrespective of whether the holder voted the stock. The GM data is from 1990, Daimler-Benz from 1986, and Toyota from 1992.

13. Gottschalk, supra note 11 , at 295.

14. Compare Table I and Gottschalk, supra note 11, with Table VIII; see also Detlev F. Vagts, Reforming the "Modern" Corporation: Perspectives from the German, 80 HARV. L. REV. 23, 53-58 (1966); Hermann H. Kallfass, The American Corporation and the Institutional Investor: Are There Lessons From Abroad?, 3 COLUM. BUS. L. REV. 775, 782-83 (1988). 
influence the firm? In the large German firm, stockholders elect half of the supervisory board, employees appoint the other half. ${ }^{15}$ The supervisory board appoints a management board and approves major corporate decisions; the management board handles day-to-day decisions. German bankers use their votes to elect bank nominees to the supervisory boards of ninety-six of the one hundred largest German firms, and in fourteen cases, a banker chairs the supervisory board. ${ }^{16}$ Although no single bank generally controls an industrial firm (Deutsche Bank's control of Daimler-Benz is exceptional), together the three German large banks can, if they act in unison, dominate the shareholding side of the supervisory board. ${ }^{17}$

To an American observer, this control over large voting blocks, rather than control over credit, is the biggest difference between the German and the American structure. ${ }^{18}$ Although bank loans helped create close relationships between bankers and managers, the importance of the "house bank" debtorcreditor relationship has faded, ${ }^{19}$ and German firms no longer rely on a single bank for credit. German banks control the proxy system, not monopolistic sources of credit.

The ownership of large firms in Japan is roughly analogous to that in Germany. Large Japanese firms typically belong to a keiretsu, a group of firms and intermediaries that own some of each others' stock, usually aggregating to ownership of half of each other's stock. ${ }^{20} \mathrm{~A}$ main bank owns $5 \%$ of the stock of the keiretsu's industrial firms, which in turn own some stock in the main bank. Generally, four other banks and insurers own blocks of stock in the industrial firms, roughly equal to $5 \%$ of the outstanding shares, thus creating a latent five-holder coalition with $20 \%$ of the outstanding stock. Japanese large firms show a persistent pattern of concentrated ownership for the past twentyfive years, as Table III shows, a pattern of concentration that prevails, not just for small or mid-sized firms, but for Japan's very largest-Toyota, Nissan, Matsushita, and Mitsubishi. In America, in contrast, the five largest holders in

15. Some employee members represent white collar workers, some represent blue collar workers, and some are union representatives.

16. Deutscher Bundestag, AChtes HauptgutaChtEN DER MONOPOLKOMMiSSION, DRUCKSACHE 11/7582, 11. Wahlperiode 202-06 (July 16, 1990) (investigative report by Monopoly Commission of German Parliament); see also THEODOR BAUMS, BANKS AND CORPORATE CONTROL 29-30 (Berkeley Law and Economics Working Paper No. 91-1, 1991).

17. Although Deutsche Bank is the largest bank, Commerzbank and Dresdner together have roughly the same number of votes.

18. True, German bankers do sit on some boards where they lack votes, as do American bankers. The contrast with the American system is not here, but in the many firms where a German banker votes $15 \%$ or more of the stock of a firm on whose board a bank employee sits. If American institutions controlled such big blocks of stock, they would also sit on the board and be taken seriously by senior managers.

19. See BAUMS, supra note 16 , at 9.

20. Michael L. Gerlach, Keiretsu Organization in the Japanese Economy, in POLITICS AND PRODUCTIVITY: THE REAL STORY OF WHY JAPAN WORKS 141, 159 (Chalmers Johnson et al. eds., 1989). 


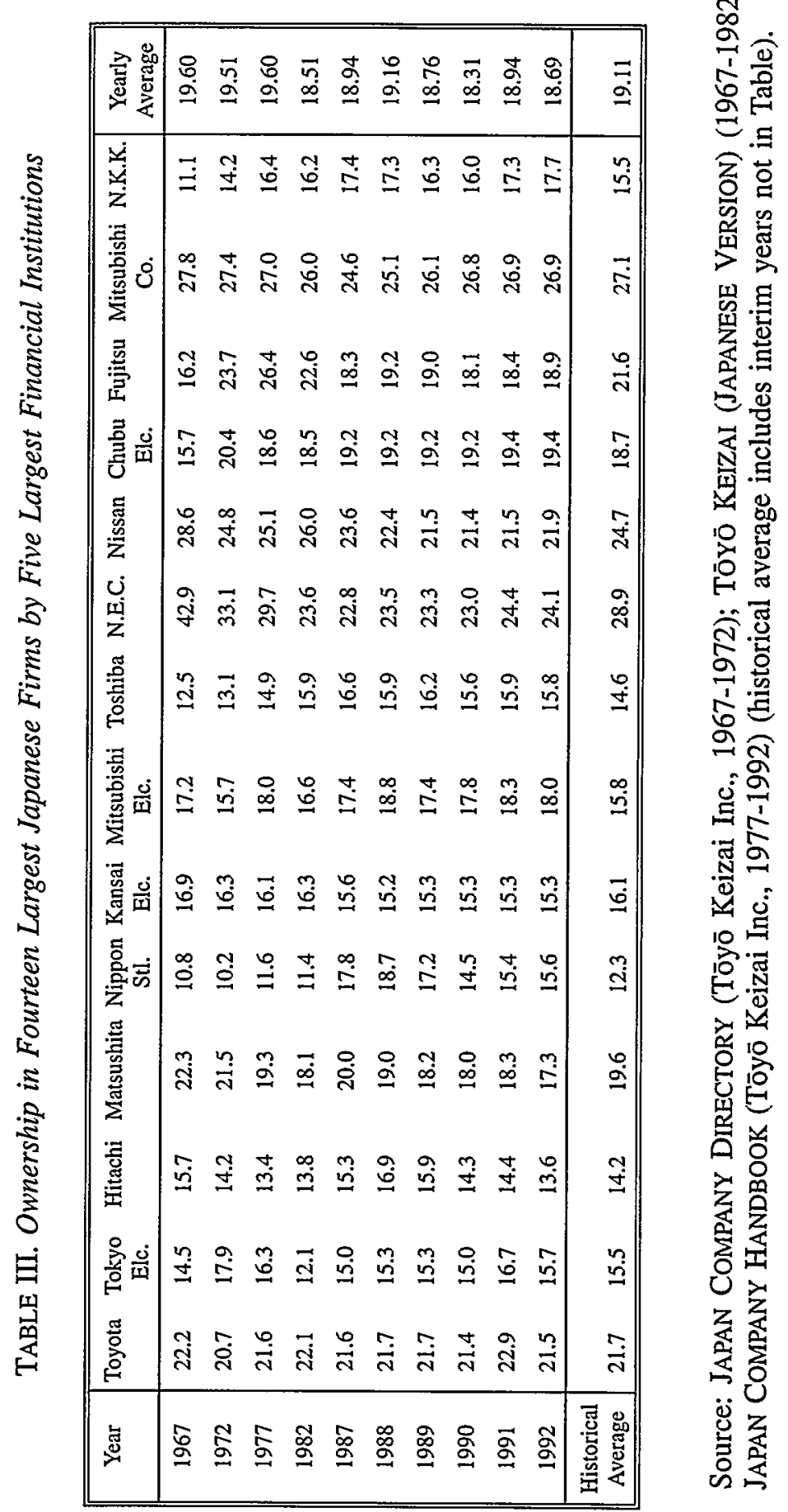


the aggregate rarely own as much as $5 \%$ of the outstanding stock of the largest firms, the amount the single largest owner typically has in Japan. ${ }^{21}$

The $20 \%$ owned by five shareholders in the largest Japanese firms is bigger than any five-shareholder block in the twenty-five largest American firms. ${ }^{22}$ In GM, Exxon, and IBM, the largest twenty-five shareholders vote less stock than the largest five stockholders in Japan's largest firms. ${ }^{23}$ If groups with twenty-five members could coordinate as well as groups with five, this would be a difference of little importance, but they cannot. ${ }^{24}$

Thus the first difference in corporate ownership structure is the concentrated voting blocks in the largest German and Japanese firms, and their absence in American firms.

\section{B. Structured Interaction}

German and Japanese CEO's regularly interact with the large owners. In German firms, the supervisory board appoints a managerial board to a fiveyear term and loosely reviews both firm and management performance, typically two to four times a year. Although the CEO and the rest of the managerial board handle day-to-day decisions, they must report to the supervisory board, which the CEO may not join, much less dominate. ${ }^{25}$

Not only do German managers not control the proxy machinery, but it is doubtful that they can even lawfully make a proxy solicitation, ${ }^{26}$ a solicitation

21. For examples, see Tables II and XIII. See generally Brancato et al., supra note 10, at app. 2 .

22. If we examine smaller American firms, however, we see levels of concentration in stock ownership that begin to approach the concentration levels typically found in Germany and Japan, although American levels still fail to exceed the concentration in the very largest Japanese firms. Compare Tables III and XI with Paul Clyde, The Institutional Shareholder as a Monitor of Management tbl. II (June 1991) (unpublished manuscript, on file with author) (showing that top five financial institutions own $18.4 \%$ of stock in sample of 511 American companies); see also Harold Demsetz \& Kenneth Lehn, The Structure of Corporate Ownership: Causes and Consequences, 93 J. POL. ECON. 1155, 1165-66 (1985) (showing that top 20 stockholders control, on average, $37.7 \%$ of outstanding stock in sample of 511 American companies).

23. Tables II and XIII show an American 5-shareholder ownership level of only 5\% and a 25institutional investor ownership level of $13.93 \%$ (GM), $11.47 \%$ (Exxon), 13.54\% (IBM), and 12.89\% (GE), an ownership level which is typical of the largest American industrial firms. See generally Brancato et. al, supra note 10, at app. 2.

24. Moreover, such groups of 25 face legal problems in coordinating. Black, supra note 9, at 536 (noting that proxy rules hinder coordination among investors); Roe, Political Theory, supra note 1 (discussing legal barriers to acquisitions of large blocks of stock by financial institutions). Some obstacles, however, were recently reduced. Regulation of Communications Among Shareholders, Exchange Act Release No. 34-31,326 [Current] Fed. Sec. L. Rep. (CCH) II 85,051 (Oct. 15, 1992); 57 Fed. Reg. 48,276 (1992) (to be codified at 17 C.F.R. $\$ \S 240,249$ ) (reducing obstacles to exchange of views among shareholders).

25. 2 ERNST GeSSLeR ET AL., AKTIENGESETZ 138-39 (1974) (commentary on § 105 of German securities law). The managerial board's ("Vorstand's") leader, or "speaker," is first among equals. Several large firms are private firms (GmbH for Gesellschaft mit beschränkter Haftung, or "firm with limited liability"), whose stock is not traded. These firms tend to have founding families who seek to maintain influence.

26. Alfred F. Conard, The Supervision of Corporate Management: A Comparison of Developments in European Community and United States Law, 82 MiCH. L. REv. 1459, 1470 (1984). 
process American managers dominate. Instead, German managers must filter proxy solicitations through bankers, who vote their own stock, their mutual funds' stock, and their customers' custodial stock. The banks obtain fifteenmonth revocable proxies from their brokerage customers, and prior to voting the custodial stock, inform their customers of their intentions, giving their customers an opportunity to instruct them to vote differently. ${ }^{27}$ Rational apathy should lead most shareholders to ignore the solicitations, and, in fact, customers rarely disapprove of their bank's recommendation. ${ }^{28}$ Bankers control the proxy machinery and hence elect the stockholding side of many supervisory boards.

It would, however, be easy to exaggerate the power of the German supervisory board. First, translation of the German board's name, Aufsichtsrat, as "supervisory board," while linguistically correct, does not quite reflect the board's authority, which is less than that of a supervisor, a position one would ordinarily suspect would yield authority to supervise. A better translation might be "advisory board," with "advisory" meaning more than just gratuitous consultation but a power similar to that of the U.S. Senate to advise and consent to treaties and appointments, which yields consultation and influence but not supervisory control.

For example, the supervisory board cannot remove the managerial board at will during its five-year term. Moreover, the managerial board co-opts some of the supervisory board's formal authority when a vacancy arises on the supervisory board, in a manner similar to, but weaker than, the American CEO's ability to name the board, by suggesting to the supervisory board who should fill the vacancy. ${ }^{29}$ German codetermination also induces shareholder representatives to want the supervisory board to supervise less than it otherwise would, because a powerful supervisory board would enhance the authority of labor's representatives on the board. The bankers generally prefer to take their chances with the managerial board. True, if there were a boardroom confrontation, the banker-shareholders could defeat the employees by relying on two features of German corporate law: First, the chair of the supervisory board is always a member of the shareholding side of the board and can cast the deciding vote in a tie; and, second, shareholders can, with a super-majority vote, send directions to the managerial board, bypassing the supervisory board. ${ }^{30}$ Thus, the supervisory board provides shareholders with

27. AKTIENGESETZ (AKTG), $\$ \$ 135(1)$-(2) (1991) (German corporations code) (authorizing revocable general proxy to banks).

28. Sprachlose Eigentümer: Aktionäre nehmen viel zu selten ihre Rechte als Inhaber von Unternehmen wahr, DIE ZEIT, June 7, 1991 (stating that small shareholders cede virtually all voting rights to large banks); see also Gottschalk, supra note 11, at 296-97; Wir sind Gerngesehene Berater, DER SPIEGEL, Sept. 4, 1989, at 45,48 .

29. Paul Windolf, Codetermination and the Market for Corporate Control in the European Community, 22 ECON. \& SOC'Y 137, 140-41 (1993).

30. Id. at 143 . 
influence, although not control, in corporate governance. Managers still have the upper hand, but the tilt is not nearly as pro-managerial as it has historically been in the United States.

Although the German pattern follows what an American corporate law scholar would predict-that large stockholders would have board seats and influence-the Japanese pattern does not. Despite concentrated voting blocks, the boards of Japanese firms are typically made up of insiders, formally elected by stockholders but usually appointed by the CEO, with at most the occasional advice and consent of the large stockholders. Stockholders usually do not appear on the board absent a crisis. Thus, the pattern that an American corporate law scholar would predict - that large stockholders would have board seats and influence-occurs only in crisis, or through an informal mechanism.

An informal mechanism for stockholder influence does exist in Japan. The financial intermediaries' leaders interact with the managers of firms in monthly keiretsu Presidents' Council meetings, which resemble a second board, analogous to the German supervisory board. Even though votes are not taken at the meetings and participants do not direct one another, individual presidents feel constrained by the consensus opinions of the council, largely because the council members are capable people who collectively control much of the stock in the president's firm. Council members are said to be consulted on major decisions, as when a CEO chooses a successor. ${ }^{31}$

Our knowledge of the details of the monthly Presidents' Council meetings is vague. Minutes are not leaked for us to examine and agendas for council action are not printed in the Japanese press. Some reports indicate that business is discussed ${ }^{32}$ while others say the meetings are purely social, ${ }^{33}$ paving the way to do business later. In the following discussion, I take the Presidents' Council to include both the meetings and the information and decisionmaking channels created through social interactions.

No single council member controls enough stock to control the others (although historically bank domination of credit yielded the bank control). Yet, since a group of these stockholders could exert control, no one member can withstand the ire of a coalition of the others; moreover, in a culture that values consensus, no one member should be willing to risk the ire of the others:

31. See W. Carl Kester, Japanese Takeovers: The Global Contest for Corporate Control 69 (1991) (describing role of keiretsu as including discussion of top personnel appointments); Charles A. Anderson, Corporate Directors in Japan, HARV. BuS. REv., May-June 1984, at 30, 32 (stating that rather than choosing a new CEO, incumbent CEO consults with the institutional owners of Iarge blocks of firm's stock and debt); $c f$. James B. Treece, 9 to 5 Japanese Style, BuS. WK., Dec. 28, 1992, at 20 (discussing subtle, indirect communication through grapevine in Japanese firms).

32. Masahiko AOKI, The ECONOMIC ANALYSIS of THE JAPANESE FIRM 3, 12 (1984) (describing Presidents' Council meetings as involving business discussions).

33. Michael L. Gerlach, Twilight of the Keiretsu?-A Critical Assessment, 18 J. JAPANESE STUD. 79, 80-81 (1992). 
These [council] meetings are not organs of decisionmaking in the sense that a majority vote would carry the day, but they are manifestations of the very dynamic process of consensus. Views are exchanged, opinions heard, and actions reciprocally adjusted, more on an ad hoc basis than in terms of binding policy.... ${ }^{34}$

The Presidents' Council is not a hierarchical command structure, but a forum for communication and perhaps a collegial monitoring of near-equals.

The power Japanese banks historically exercised over credit complicates any inquiry into the influence of institutional stockholders. When Japanese firms were rapidly expanding after the Second World War, they sought new funds from the banks, through which Japan channeled credit. The banks' power to cut firms off from funding for new projects yielded the banks sufficient influence, irrespective of their stockholding.

Both stock and debt are relevant in the prevailing models, which see delegated monitoring among Japanese banks, by which six banks buy stock in, and make loans to, several firms. The banker-group assigns each borrowing firm a "main bank" to which the other banks delegate monitoring tasks. In these models, the main bank speaks with the authority of both creditors and stockholders owning $20 \%$ of the firm's stock. ${ }^{35}$

The joint causation problem does not make stock irrelevant and, if banks' power over credit allocation continues to weaken, we shall see whether stock alone gives them influence. There is reason to believe that, although individual stockholders are powerless, intermediaries have influence through their stock. Although Japanese culture may deter large stockholders from formally firing the CEO, mild criticism in a Presidents' Council meeting may shape actions in a culture that values harmony. Bankers do send in directors when serious problems arise and performance weakens. ${ }^{36}$ The CEO may stay in place, but with diluted authority, or the CEO may be "promoted" to the less powerful position of chairperson. In 1992, the CEO's of $14 \%$ of all Japan's public companies left, about one-third of them involuntarily. ${ }^{37}$ Moreover, when

34. Robert J. Ballon \& IWaO TOMita, THE FinanCial Behavior of Japanese Corporations 68 (1988); see also Michael L. Gerlach, AllianCe Capitalism: The Soclal Organization of JAPANESE BUSINESS 108 (1992) (describing power of Presidents' Council members as implicit influence that is continually negotiated); Anderson, supra note 31, at 30 (stating that Japanese corporate governance "appears to take place behind the scenes between the senior corporate official and the major institutional shareowners").

35. Paul Sheard, The Main Bank System and Corporate Monitoring and Control in Japan, 11 J. ECoN. BEHAV. \& ORGANIZATION 399 (1989).

36. Steven N. Kaplan \& Bernadette Alcamo Minton, "Outside" Intervention in Japanese Companies: Its Determinants and Its Implications for Managers (Sept. 1992) (unpublished manuscript, on file with author); Randall Morck \& Masao Nakamura, Banks and Corporate Control in Japan (Sept. 1, 1992) (unpublished manuscript, on file with author).

37. ...And in Japan, FORTUNE, Feb. 22, 1993, at 10 (reporting ousters, although not explicitly tying ousters to stockholder initiatives). Although Japanese cross-ownership could insulate presidents from ouster, see John C. Coffee, Jr., Liquidity Versus Control: The Institutional Investor as Corporate Monitor, 91 COLUM. L. REV. 1277, 1298-99 \& n.82 (1991), the turnover and ousters indicate the insulation is 
informality fails and confrontation ensues, stockholding banks have taken control of the board and dismissed the CEO. When a scandal in a large department store chain implicated the $\mathrm{CEO}$, who uncharacteristically refused to resign, the Mitsui Presidents' Council decided to replace him, and the banker on the store's board engineered the coup de grace. ${ }^{38}$ Formal action is probably usually unnecessary; in a small group, large shareholders should have only to raise their voice to assert influence. ${ }^{39}$

Other incidents, such as Japanese greenmail-twenty-two instances in the 1980 's - and a successful hostile takeover, indirectly suggest shareholder power. ${ }^{40}$ Moreover, Japanese managers face fractious annual stockholder meetings, which they control reasonably well because they go to the meetings armed with proxies from their large shareholders. ${ }^{41}$ Obviously, if the large stockholders denied managers the proxies, managers would face more difficult annual meetings. Finally, stockholding institutions unhappy with managers can threaten to sell their stock, leaving managers at the risk of a takeover. Not only have Japanese commentators described this potential as an important theoretical source of stock-based influence, ${ }^{42}$ but financial intermediaries have publicly made such threats. ${ }^{43}$

In both the German and the Japanese large firm, structured interaction between stockholding intermediaries and corporate managers enables bankers to influence managers' actions, but not to control them completely. ${ }^{44}$ In Germany, managers can ally with employees, who hold half of the seats on the board. Since the large voting blocks are typically split among a handful of banks, the intermediaries must form a coalition to challenge an alliance between managers and employees. In Japan, banks are not represented on the board, except in crisis. And, since bank-controlled stock is typically split among a handful of banks, a main bank must form a coalition to act. The

incomplete. If cross-holdings were fully protective, they would not allow roughly one out of every 20 CEO's to be involuntarily ousted in a single year. The insulation hypothesis may confuse intent with effect; cross-holdings arose primarily because managers wanted to stave off takeovers and uncertainty, but friendly $5 \%$ shareholders turn unfriendly when results are poor. Or the insulation hypothesis might have seemed warranted when the Japanese economy was humming along and good results shielded even second-rate managers from inquiry.

38. GERLACH, supra note 34 , at 111-13.

39. Japanese corporate law poses no barrier, because it allows shareholders to remove directors without cause at any time. AOKI, supra note 32 , at 10.

40. KESTER, supra note 31 , at $17,247-48$.

41. Merton J. Peck, The Large Japanese Corporation, in THE U.S. BUSINESS CORPORATION: AN Institution IN TRANSTTION 21, 22 (John R. Meyer \& James M. Gustafson eds., 1988).

42. Kunio Ito, M\&A to Kabushiki Mochiai no Honshitsu, KINYU J., Dec. 1989, at 11.

43. Insurance companies have, in recent years, been unhappy with dividend payouts and have threatened to dump the stock of companies that fail to increase their dividends. The observed threats are the tip of an iceberg - of uncertain size-of private influence. See Stephen D. Prowse, The Structure of Corporate Ownership in Japan, 47 J. FIN. 1121, 1138-40 (1992). The insurers' demands may not arise directly from firms' misuse of cash, but from the insurers' need to receive larger dividends to comply with insurance regulations. I offer this item to show shareholder power, not to show that it is always used to improve corporate governance.

44. There are exceptions, such as Deutsche Bank's dominant $28 \%$ block in Daimler-Benz. 
resulting authority structure is flatter than the one in the United States because the CEO seems unable to dominate decisionmaking. And since no single intermediary can dominate, but must form a coalition to amass a dominating block of stock, the foreign governance structure is not equivalent to replacing an American-style dominating $\mathrm{CEO}$ with a dominating institution. Thus, structured interaction, without a shift in day-to-day control, is the second major structural difference between the foreign firms and the American.

\section{Size of Foreign Financial Intermediaries}

The third major structural difference is in the size of the financial intermediaries. The largest German and Japanese financial institutions play a much bigger role in their economies than the largest American intermediaries play in the American economy. Size and strength facilitate holding big blocks of stock, a holding that is difficult to achieve here in relatively smaller intermediaries. ${ }^{45}$

The largest three German banks have assets equal to $36 \%$ of German gross national product. The assets of the largest three American banks, in contrast, are equal to only $7 \%$ of the American GNP, making the German banks about five times "stronger" than the largest American banks. Similarly, the largest banks in Japan, a country with a GNP about $60 \%$ of that of America, are several times larger than their American counterparts.

TABLE IV. Summary of Bank Size in Germany, Japan, and America ${ }^{46}$

\begin{tabular}{|c|c|c|c|c|c|c|c|}
\hline Country & $\begin{array}{l}\text { Assets of } \\
\text { Largest } \\
\text { Three } \\
\text { Foreign } \\
\text { Banks (1) }\end{array}$ & $\begin{array}{l}\text { Assets of } \\
\text { Largest } \\
\text { Three } \\
\text { American } \\
\text { Banks (2) }\end{array}$ & $\begin{array}{l}\text { Foreign } \\
\text { GNP (3) }\end{array}$ & $\begin{array}{l}\text { American } \\
\text { GNP (4) }\end{array}$ & $\begin{array}{l}\text { Relative } \\
\text { Size of } \\
\text { Foreign } \\
\text { Banks (5) } \\
{[(1) /(3)]}\end{array}$ & $\begin{array}{l}\text { Relative } \\
\text { Size of } \\
\text { American } \\
\text { Banks (6) } \\
{[(2) /(4)]}\end{array}$ & $\begin{array}{l}\text { Ratio of } \\
\text { Foreign Size } \\
\text { to American } \\
\text { Size } \\
{[(5) /(6)]}\end{array}$ \\
\hline Germany & $\$ 600 \mathrm{~B}$ & $\$ 424 \mathrm{~B}$ & $\$ 1.65 \mathrm{~T}$ & $\$ 5.5 \mathrm{~T}$ & 0.36 & 0.08 & 4.50 \\
\hline Japan & $\$ 1,345 \mathrm{~B}$ & $\$ 424 B$ & $\$ 3.44 \mathrm{~T}$ & $\$ 5.5 \mathrm{~T}$ & 0.39 & 0.08 & 4.88 \\
\hline
\end{tabular}

45. The largest three American banks are much weaker players in the American economy than the largest German and Japanese banks are in their respective economies. See Table IV. These disparities in strength persist even if we compare each nation's largest ten banks. See Table V. Although current exchange rates disfavor the dollar, using bank assets as a percentage of GNP, as in Table IV, eliminates the exchange rate distortion.

46. Source: Calculated from Table V. 
TABLE V. Assets of Ten Largest German, Japanese, and American Banks (in Billions of Dollars) ${ }^{47}$

\begin{tabular}{||lr|lr|lr||}
\hline \multicolumn{2}{|l|l|l||}{ Ten Largest German Banks } & \multicolumn{2}{|l|}{ Ten Largest Japanese Banks } & \multicolumn{2}{l|}{ Ten Largest American Banks } \\
\hline Deutsche Bank & 267 & Dai-Ichi Kangyo & 435 & Citicorp & 216 \\
Dresdner Bank & 189 & Sumitomo & 407 & Bank America & 110 \\
Commerzbank & 144 & Fuji & 403 & Chase Manhattan & 98 \\
Bayerische V-Bank & 138 & Mitsubishi & 392 & J.P. Morgan & 93 \\
D. Genossen-Bank & 137 & Sanwa & 387 & Security Pacific & 85 \\
Westdeutsche & 137 & Industrial Bank of Japan & 285 & Chemical Bank & 73 \\
Bayerische H\&W & 117 & Tokai & 246 & NCNB & 65 \\
Bayerische L-Bank & 114 & Bank of Tokyo & 228 & Bankers Trust NY & 64 \\
Nord-d Landesbank & 83 & Mitsubishi Trust & 226 & Manufacturers Hanover & 62 \\
Sudwest-d L-Bank & 59 & Norinchukin & 224 & Wells Fargo & 56 \\
\hline Total & 1,385 & Total & 3,233 & Total & 922 \\
\hline
\end{tabular}

47. Source: Adapted from The Global Service 500: The 100 Largest Commercial Banking Companies, ForTUNE, Aug. 26, 1991, at 174-75.

Because American banks are relatively small, inserting the largest mutual fund complexes and the largest insurers into Table $\mathrm{V}$ would make a difference, but not much of one:

TABLE Va. Assets of Ten Largest American Banks, Insurers, and Mutual Fund Complexes (1990, 1992)

\begin{tabular}{||lc||}
\hline Financial Institution & Assets \\
\hline Citicorp & \$217B \\
Fidelity & \$164B \\
Prudential & $\$ 133 \mathrm{~B}$ \\
Bank America & \$110B \\
Merrill Lynch & \$107B \\
MetLife & \$103B \\
Chase Manhattan & \$98B \\
J.P. Morgan & \$93B \\
Vanguard & \$93B \\
Security Pacific & \$85B \\
\hline Total & \$1,202B \\
\hline \hline
\end{tabular}

Source of asset size of insurers and mutual funds: CAROLYN KAY BRANCATO, INSTITUTTONAL INVESTORS: A WIdely Diverse PRESENCE in CORPORATE GovernanCE, tbls. 9, 12 (Background Paper Prepared for Columbia Institutional Investor Project, Center for Law and Economics, Feb. 25, 1993). The mutual fund numbers are somewhat overstated because they are from 1992, while all other numbers are from 1990, and mutual funds grew from 1990 to 1992 . Adding American pension funds would not make a big difference. TIAA-CREF, the largest pension fund with $\$ 99$ billion worth of assets, would make it to the bottom of the list. Calpers, the next largest pension fund, would not. Top 200 Pension Funds/Sponsors, PENSIONS \& INVESTMENTS, Jan. 20, 1992, at 20. Expanding Table V to include insurers would add Allianz to the German list ( $\$ 119$ billion), but would not change the Japanese list. The Global Service 500, FORTUNE, Aug 24,1992 , at 215 . 
The relatively small size of American financial institutions, however, makes it harder for them to buy a large block of stock in GM, Exxon, or IBM than it is for the foreign banks to buy $28 \%$ of Daimler-Benz or 5\% of Toyota.

$* * * * *$

Let us summarize. Concentrated blocks, shared authority, and big intermediaries are the three key structural differences.

Although we do not know exactly how the foreign structures work, and the data is too thin to indicate whether they work well, we must not miss the main point here. The foreign corporate structures differ greatly from those prevailing in America. German and Japanese senior managers share power with large financial intermediaries, which own and vote big blocks of stock and are active in corporate governance, formally through supervisory boards in Germany, and informally through Presidents' Councils in Japan. The survival of these foreign firms over several decades suggests that the classical economic model of the firm must be reinterpreted as a special case in the U.S. setting because firms can prosper with different governance structures. These differences appear to correlate, not so much with differences in economic task, but with differences in the organization of financial intermediaries. Concentrated blocks, shared authority, and powerful intermediaries are not only uncommon here in America; they have also been, as we next see, illegal.

\section{American Banking Regulation}

The organization of financial intermediaries deeply determines the structure of corporate ownership, and law deeply determines the organization of financial intermediaries. We can see this syllogism vividly illustrated by testing whether or not U.S. firms and intermediaries could imitate the foreign structures without violating America's basic laws.

Size is central. Large American banks play a role in the American economy equal to only one-quarter of the role played by large banks in Germany and Japan. ${ }^{48}$ This difference in size correlates with law. American legal restrictions have historically kept American banks small and weak, by banning them from operating nationally, entering commerce, affiliating with investment banks, equity mutual funds, or insurers, or from coordinating stockholdings with these other intermediaries.

The National Bank Act of 1863 historically confined national banks to a single location, and the McFadden Act of 1927 only allowed branches of national banks to the extent state law permitted. ${ }^{49}$ Although states may permit out-of-state banks to open local branches, until recently they did not, and even

48. Table IV.

49. National Bank Act of 1863 , ch. $106, \S 44,13$ Stat. 99 (1863) (codified as amended at 12 U.S.C. $\S 38$ (1988)); McFadden Act, ch. 191, § 1, 44 Stat. 1224 (1927) (codified as amended at 12 U.S.C. § 36 (1988)). 
the recent permissions are incomplete. Although federal law could override state law and permit interstate branching, it does not. America still lacks a truly national banking system like that of other nations, including Germany and Japan.

American banks have also faced product limits. The Glass-Steagall Act has historically denied banks a securities business and close affiliation with investment banks and, until recently, mutual funds. ${ }^{50}$ The Bank Holding Company Act prohibits affiliation with insurers and fine-tunes Glass-Steagall by prohibiting bank affiliation with nonbanks, except passive ownership of no more than $5 \%$ of a nonbank's stock.

Lastly, American deposit insurance historically encouraged weak bank capitalization, which limited banks' ability to make large equity investments. Bank managers can raise the private value of bank stock by keeping their equity thin and displacing some of the risks of bank failure onto the public. ${ }^{51}$ By encouraging low levels of capital, extensive deposit insurance has made many banks too weak to own much stock. If deposit insurance were less extensive, banks would be pressed to raise more equity, either by market forces or by new bank regulation, to attract uninsured deposits and to avoid bank runs. $^{52}$

\section{German Universal Banks in the United States?}

If U.S. banks tried to imitate German banks, they would smash into nearly every U.S. financial regulation. German banks not only have a national scope that would violate McFadden's geographic restrictions ${ }^{53}$ but they also hold nearly two dozen large positions in the one hundred largest German firms and thus would violate both the U.S. ban on bank stock ownership and the $5 \%$

50. Act of June 16, 1933, ch. 89,48 Stat. 162 (codified as amended in scattered sections of 12 U.S.C.). Bank sponsorship of mutual funds, historically banned and only very recently accommodated under banking law, is exploding, despite the fact that some of it is still in a legal gray area. Leslie Wayne, Questions on Bank Sales of Funds, N.Y. TMMES, Dec. 31, 1992, at C1 (noting explosive sales growth); Prospectus for Vista Capital Growth Fund 8 (Feb. 28, 1992) (on file with author) (prospectus of equity mutual fund sponsored by Chase Manhattan Bank concedes cloudy legality under Glass-Steagall of bank sponsorship). Other restrictions are slowly eroding, particularly those that confine banks to the narrow business of commercial banking. Nevertheless, the historical restrictions have important continuing effects because they made American banks weak, and the weak banks will need years to evolve into stronger ones.

51. Thus, while the historical sequence was that Congress prohibited bank stock ownership first (in . 1863 by the National Bank Act and in 1933 by Glass-Steagall) and then added deposit insurance (in 1934), we could think of the justification for the prohibition as coming in the reverse order. Once Congress established extensive deposit insurance, it also had to control the banks' level of risk and prohibiting stock ownership was part of that control.

52. Recent regulatory initiatives forcing banks to increase their equity have been successful. Whether unregulated banks would increase their own equity to enable them to hold stock in other firms would depend on whether the costs of holding big blocks of equity-such as lost liquidity and increased risk-outweighed the benefits. I outline some of the considerations below in Part V. There is, however, one unnerving fact in favor of equity: stock persistently yields a higher return than debt. Andrew Abel, The Equity Premium Puzzle, Fed. Res. BANK PhIL. MONTHLY Rev., Sept. 1991, at 3.

53. McFadden Act, Pub. L. No. 69-639, 44 Stat. 1224, 1228 (1927). 
limit on bank affiliate ownership of a nonbanking firm's stock. ${ }^{54}$ In addition, the largest German banks are also the largest brokerage houses, and they control the proxy machinery, which would violate the historical product restrictions of the Glass-Steagall Act. If U.S. banks were to act as brokers, stock exchange rules would prohibit them from voting their customers' stock on anything important, ${ }^{55}$ while German bankers can vote their customers' stock on anything at all, and they do.

German banks combine modest direct holdings of stock with extensive holdings of custodial stock. American banks might try to imitate them by combining modest stock holdings in affiliates with their extensive holdings of trust stock. ${ }^{56}$ The American banks would face several obstacles, the first of which arises from trust law, which tends to induce the hyper-fragmentation of portfolios, to reward passivity, and to reinforce America's dominant investment norms of passivity. ${ }^{57}$

Trust law is a sufficient bar, but not the only one. A formal combination of holding company stock and trust stock via the bank giving a proxy to the holding company would probably violate the Bank Holding Company Act, which prohibits bank affiliates from controlling more than 5\% of a firm's stock..$^{58}$ An informal combination via consciously parallel voting would, by itself and if the banks did nothing more, seem to be within the limits of the Act. But its success would still depend on how aggressive the regulators would be in applying interpretations that required holding companies to hold stock passively. During an earlier manifestation of bank power through trust stock, Congress held extensive hearings and, through the vehicle of Wright Patman's House Banking Committee, castigated banker power derived from owning stock in trust accounts and implicitly threatened banks with political costs if they used trust stock to exert influence in corporate governance. ${ }^{59}$ Although we can only speculate as to whether these political forces would arise again if banks tried to assert influence, we know that they did once arise and induced

54. See Table VIII.

55. See, e.g., NEW York STOCK EXCHANGE, LISTED COMPANY MANUAL II 402.06(D) (looseleaf 1990), analyzed in Black, supra note 9, at 560-61; see also Conard, supra note 26, at 1469-70. Technically, American banks cannot be regulated as brokers, but they nevertheless were not permitted, until very recently, to operate brokerage firms, making the "freedom" from broker-dealer regulation moot. Again, the American restrictions are partly historical; these features of Glass-Steagall are eroding.

56. The Glass-Steagall Act prohibits banks from themselves acquiring any stock.

57. See Black, supra note 9, at 526-30; Jeffrey N. Gordon, The Puzzling Persistence of the Constrained Prudent Man Rule, N.Y.U. L. ReV. 52, 96-99 (1987); Mark J. Roe, Institutional Fiduciaries in the Boardroom, in INSTITUTIONAL. INVESTING: CHALLENGES AND RESPONSIBILITIES IN THE 21ST CENTURY 292 (Amold W. Sametz \& James L. Bicksler eds., 1991); Mark J. Roe, The Modem Corporation and Private Pensions (Apr. 1993) (unpublished manuscript, on file with author) [hereinafter Roe, Modern Corporation].

58. Bank Holding Company Act of 1956, ch. 240, $\$ 4(c)(6), 70$ Stat. 133 (1956) (codified as amended at 12 U.S.C. $\S 1843(\mathrm{c})(6)(1988))$.

59. STaFf of SubComm. on Domestic FinanCe of House Comm. ON Banking and CuRRENCY, 89TH CONG., 2D SeSS., REPORT ON BANK STOCK OWNERSHIP AND CONTROL 10 (Comm. Print 1966). 
prominent practitioners to warn banks not to use trust fund stock to build control blocks. ${ }^{60}$

In any case, had American banks during most of this century tried to imitate the Germans, they would have failed since they have been barred from operating nationally, from entering the securities business, from using affiliates to take blocks above 5\%, and probably also from using trust stock to be active. McFadden, Glass-Steagall, the Bank Holding Company Act, and trust law each seem sufficient to have deterred American bankers, who, if they tried to imitate the German bankers, would have had to run their banks from jail.

\section{Japanese Main Banks in the United States?}

Japanese bank and insurer groups commonly control $20 \%$ of the stock of a large firm, intervene during crises, and meet with managers during monthly Presidents' Council meetings where, according to some, ${ }^{61}$ they reach consensus on direction and operations. Could this system work under U.S. law, as some commentators assert, because no bank in the group owns more than $5 \%$ of a firm's stock, the amount permitted a bank holding company-but not a bank-under U.S. banking law? In other words, can American bank holding companies be active in corporate governance and take control in crisis as long as they limit their stock ownership to $5 \%$ of a firm's outstanding shares?

American "main" banks would suffer from the geographic and product limitations that make them puny compared to Japanese banks. As Table V shows, while the assets of Japan's ten largest banks are over $\$ 3$ trillion, the assets of America's ten largest banks do not total even $\$ 1$ trillion-and the American economy is larger than Japan's. No U.S. bank has the financial strength needed to purchase a 5\% stake in GM easily or to extend a huge loan without heavy syndication. The risk to a small American bank taking a big slice of a large industrial firm's capital was historically heightened by geographic restraints, which led to underdiversified assets and deposits. A bigger Japanese bank can purchase a 5\% stake in Toyota without incurring the same risks. ${ }^{63}$

Small size is enough to make law a complete barrier to an American main bank system or America's largest firms. The Glass-Steagall Act adds to this

60. Raymond A. Enstam \& Harry P. Kamen, Control and the Institutional Investor, 23 Bus. LAW. 289, 290-91 \& n.14 (1968); A. A. Sommer, Jr., Who's "In Control?"-SEC, 21 BUS. LAW. 559, 570 (1966).

61. See supra notes $32-34$ and accompanying text.

62. I've heard this argument at a number of conferences. Coffee in particular argues that because the 5\% limit on stock ownership is common to both the U.S. and Japan, legal differences are unimportant. Coffee, supra note 37, at 1295.

63. See Table X. Nor would the ability of one bank to take a big block be likely to suffice. There is reason to think that multiple blocks make the system work, meaning that an American main bank system might need a half-dozen or dozen financial firms with the strength to take big blocks in multiple industrial firms. 
barrier by blocking the bank from owning stock anyway. And the Bank Holding Company adds yet more to this barrier by encouraging banker passivity in wielding stock that affiliated companies own. ${ }^{64}$ The Act begins by proscribing not just control of an industrial firm, but (subject to exceptions) ownership or control of any voting stock in an industrial firm.

Except as otherwise provided in this chapter, no bank holding company shall-

(1) after May 9, 1956, acquire direct or indirect ownership or control of any voting share of any company which is not a bank. ... ${ }^{65}$

In the most aggressive interpretation of the prohibition, Citicorp would violate section 4(a) by accepting an irrevocable proxy to vote a single share of GM stock. The Act then carves out an exception: the holding company may own "shares of any company which do not include more than 5 per centum of the outstanding voting shares of such company. . . ."66 But, arguably, a holding company that combined affiliate stock with trust stock by owning $5 \%$ and taking proxies for another $15 \%$ of the outstanding shares would "acquire ... indirect ... control of . . . voting share[s] of any company which is not a bank"67 in excess of the 5\% exemption, and thereby would violate the Act.

An American banking group could try to overcome the $5 \%$ barrier by parallel action. Five banks and insurers could each own 5\%; a main bank would nominate directors; and all would vote their $5 \%$ for the nominees. This parallel action, even if coordinated with interbank discussion, would comply with the words of the statute but still face two banking law problems, one general and one specific. (It would face securities law and other problems too). First, Congress castigated American banks as recently as the 1960's for having more subtle means of influence, leading lawyers to recommend that banks keep away from such boardroom power. ${ }^{68}$ Second, the Federal Reserve Board rejected a roughly similar proposal as banned by the Act:

[I]nvestments made in reliance on [the $5 \%$ permission in] [S]ection 4(c)(6) must be essentially passive ... [S]ection 4(c)(6) is not an unqualified grant of permission for a bank holding company to acquire or retain a 5 percent voting interest in any company. It is the

64. Thus, astute legal analysts' claims that law does not matter because banks in both Japan and America face identical 5\% limits on stock ownership are puzzling, since neither the stunting caused by the McFadden Act nor the passivity rules of the Bank Holding Company Act are discussed. See, e.g., Coffee, supra note 37 , at $1278-81,1294-95$.

65. Bank Holding Company Act of 1956, ch. 240, § 4(a), 70 Stat. 133 (1956) (codified at 12 U.S.C. $\S 1843(a)(1)(1988)$ ) (emphasis added). To be precise, an American bank cannot own any stock: the permitted ownership is for a bank holding company. This distinction probably increases the costs of certain transactions, but I assume that the effect is not large.

66. Id. $\S 4(\mathrm{c})(6), 12$ U.S.C. $\S 1843$ (c)(6) (1988).

67. Id. § 4(a), 12 U.S.C. § $1843(\mathrm{a})(\mathrm{I})$ (1988).

68. See supra note 59 and accompanying text. 
Board's view that the prohibition against bank holding companies' engaging in nonbanking activities extends to joint ventures or concerted action by a group of bank holding companies in a nonbanking activity as entrepreneurs." ${ }^{.69}$

Congress did not, with the 5\% rule, unleash banks to use small blocks of stock to gain influence in corporate boardrooms, or at least so ruled the Federal Reserve. ${ }^{70}$ Later the Board reiterated that it "believes that section 4(c)(6) should properly be interpreted as creating an exemption from the general prohibitions ... on ownership .... only for passive investments amounting to not more than 5 percent ....".71

These explicit passivity interpretations were somewhat undercut by an earlier Federal Reserve Board interpretation concerning, ironically enough, keiretsu main bank cross-ownership. For a time the Bank Holding Company Act, if read literally, prohibited Japanese banks operating in the United States from owning stock in Japanese companies located in Japan. Although the Fed never enforced the extraterritorial reach of the Act, saying it was meant to apply to U.S. commerce, not Japanese commerce, ${ }^{72}$ the Board asked Congress to amend the Act when many foreign banks entered the United States in the 1970 's, ${ }^{73}$ and Congress did. $^{74}$

These passivity rules could break down through regulatory reinterpretation, just as regulatory reinterpretation has expanded banks' securities power in recent years, because the rulings come not from the clear command of the statute, but from the Fed's plausible interpretation of that statute. Although they may seem to be minutiae, they really are not, because they complete the broad congressional policy preference exhibited in McFadden's branching restrictions, Glass-Steagall's stock ownership restrictions, and the Bank Holding Company Act's line-of-business restrictions: to keep banks small, to

69. 4 F.R.R.S. 4-338.2, Jan. 22, 1986, available in LEXIS, Bankng library, FRRS file (Federal Reserve Board ruling regarding whether activities of mutual insurance company are "closely related to banking").

70. Because the statute does not explicitly require passivity for a $5 \%$ blockholder and does not explicitly cover the informal relationships in Japan, the words of the statute are ambiguous. In the Federal Reserve Board's interpretation, if the main bank is not passive, it violates the Act, but a literalist might interpret the statute differently.

71. 12 C.F.R. $\$ 225.137$ (1990) (emphasis added). See generally PAULINE B. HELLER, FEDERAL BANK HOLDING COMPANY LAW $\$ 4.03[2][a]$, at 4-60.9 (1992).

72. And then, since the Act did not exempt foreign banks' foreign operations from the Act's reach, the Fed did not adopt its subsequent passivity interpretations and said that activity, as long as there was no control, passed muster. In re Dai-Ichi Kangyo Bank, 58 Fed. Res. Bull. 49, 49 (1972) ("Ii]n light of the [Act's] purpose ... to maintain separation of banking from commerce in the United States.") (emphasis added).

73. INTERNATIONAL BANKING ACT OF 1978, S. REP. No. 1073, 95th Cong., 2d Sess. 1 (1978). Actually, the Federal Reserve Board sought Congressional action even before 1972. International Banking Act of 1976: Hearings Before the Subcomm. on Financial Institutions of the Senate Comm. on Banking, Housing and Urban Affairs, 94th Cong., 2d Sess. 21, 30 (1976) (statement of Fed Vice Chairman Gardner quoting 1970 Senate testimony of Chairman Burns).

74. International Banking Act of 1978, Pub. L. 95-369, § 8(e), 92 Stat. 623 (1978) (codified at 12 U.S.C. $\S 1841(\mathrm{~h})(2)(1988))$. 
keep private economic power unconcentrated, and to put a fault line between banking and industry.

\section{Main Banks and Universal Banks-The Potential for Control}

If American banks tried to imitate either the Japanese main banks or the German universal banks, the Act would still deter them if the Fed revoked its passivity rule and allowed activity short of control. ${ }^{75}$ Large investors want the option to exert control, even if they rarely exercise it. When Berkshire Hathaway buys a big block of stock and sits on a firm's board, it does not want day-to-day control. It does, however, want the freedom to take control-to replace the CEO in a crisis as it did in the recent Salomon Brothers scandal. Short of crisis, large shareholders with the potential to exert control are more influential if not barred from control. Since crisis intervention is a key function of the foreign systems, a regulatory bar on control is a steep barrier. $^{76}$

U.S. banks can and sometimes do assert control over firms, particularly small firms ${ }^{77}$ as lenders, without violating the Bank Holding Company Act. Banks whose holding companies own stock should be shy of doing so, because the source of control - debt or stock-would probably be unclear. Indeed, stock can support the loan because in crisis stock can yield control by voting in new directors faster than debt can yield control by enforcing covenants in bankruptcy. Moreover, even if U.S. banks can show that their control came from lending, not owning stock, the stock heightens the risk of equitable subordination of their loans in bankruptcy and claims of lender liability outside bankruptcy. Unlike main banks in Japan, which are subordinated by custom, informal agreement, and Ministry of Finance guidance, U.S. creditors can avoid equitable subordination (and lender liability) by inaction. ${ }^{78}$ The main bank, already subordinated, can improve its return on its loan by fixing the firm that is in crisis, not by ignoring the crisis.

75. When the literal reading of the statute prohibited Japanese banks from acquiring American banks if they were active in commerce in Japan, the Fed interpreted $\$ 4(c)(6)$ as prohibiting only control, not activity. See supra text accompanying note 72 .

76. Paul Sheard, The Role of the Japanese Main Bank When Borrowing Firms are in FINANCIAL DISTRESS (Stanford Center for Economic Policy Research Working Paper No. 330, 1992).

77. Thus, I understand that some banks involved in leveraged buyouts have accepted the risks outlined in this section.

78. See, e.g., Taylor v. Standard Gas \& Electric Co., 306 U.S. 307 (1939); State National Bank of El Paso v. Farah Mfg. Co., 678 S.W.2d 661 (Tex. Ct. App. 1984); J. Mark Ramseyer, Japanese Main Banks as a Regulatory Artifact: The Legal Framework (1991) (unpublished manuscript, on file with author). 


\section{Main Banks and Universal Banks-The Suppression and Capture of the Securities Market}

A society can move savings from households to firms through strong stockholding intermediaries or through a securities market. America's GlassSteagall Act severed the intermediary channel from the securities channel, weakening American intermediaries by creating two channels. In Germany, the banks captured the securities channel; the German securities market is weak, and the banks substantially control it, a result that allows for powerful intermediaries, which can provide both banking and securities services to firms and households. As we have seen, a big part of the German banks' voting power comes from securities owned by the banks' customers and deposited with the banks.

The Japanese situation is more complex. One might think that because Japan has a Glass-Steagall Act-imposed on it during the American postwar occupation-it would resemble America in having two channels. One might then mistakenly argue that because Japan has a Glass-Steagall Act, GlassSteagall did not restrain the development of powerful U.S. banks.

But such an argument misunderstands Japan's Glass-Steagall Act. In fact, until recently Japan has more resembled Germany in having essentially one channel. Like the American version, the Japanese Act severed commercial banks from investment banks. But the Japanese system then took a different path: Japanese postwar regulation skewed industry financing toward banks and away from the securities market by (1) suppressing the bond market through collateralization and issuance regulations: ${ }^{79}$ (2) limiting competing sources of corporate finance, such as equity issuance; ${ }^{80}(3)$ impeding the development of investment companies; ${ }^{81}$ (4) requiring that banks serve as trustees for bondholders when companies were allowed access to the bond market; ${ }^{82}$ and (5) holding down the interest rates paid on deposits to enable banks to profit even when lending at low rates.

Properly understood, postwar Japan adopted two offsetting sets of regulations. One set segmented finance but was not as severe as U.S. regulation-although Japanese banks could not issue securities, sell insurance or own very large blocks of stock, they could become large and be active in corporate governance. The second set channeled finance through banks by

79. Frances MCCall Rosenbluth, Financial Politics in CONTEMPorary Japan 157-66 (1989).

80. ROBERT ZIELINSKI \& Nigel HOLlOWAY, UNEQUAL EQUTTES: POWER AND RISK IN JAPAN'S STOCK MARKET 156 (1991); Ramseyer, supra note 78, at 23-31; MIKUNI \& Co., BANKING 5 (Occasional Paper No. 2, 1987).

81. Hideki Kanda, Politics, Formalism, and the Elusive Goal of Investor Protection: Regulation of Structured Investment Funds in Japan, 12 U. PA. INT'L L. REV. 569 (1991).

82. MASAHIKo AOKI, THE JAPANESE FIRM AS A SySTEM OF ATTRIBUTES: A SURVEY AND RESEARCH AGENDA 17-18 (Stanford Center for Economic Policy Research Publication No. 288, 1992). Thus Japan pushed corporate borrowers into commercial banks and limited savers' options. 
ensuring that depositors had few options other than banks and that large corporate borrowers had few nonbank financing sources. ${ }^{83}$ Thus, Japan effectively "repealed" the American imposed Glass-Steagall separation, not by allowing commercial banking to mix with investment banking, but by stymieing a securities market and channeling savings and corporate financing into the banking system. ${ }^{84}$

Hence, although laws in both nations severed investment banking from commercial banking, the results differed, because, unlike the Americans, the Japanese allowed their banks nationwide operations, forced savers to use banks on terms favorable to the banks, and required corporations to seek financing through the banks. In operation, Japan did not have the Glass-Steagall Act that America had. America constructed two big competing financial channels; Japan channeled both savings and finance through the banks. The single channel allowed the Japanese banks to be powerful enough to take a serious role in corporate ownership.

The Japanese single channel for finance is now weakening for two reasons. Success has given Japanese firms the luxury to retain earnings, thereby sidestepping the banks' control over the financing channel. (This success and the side-stepping it facilitated now make the banks' control over stock potentially more important than it has been.) Also, the channelling regulations that once offset Glass-Steagall are disappearing. Regulatory change has opened up the securities channel a bit, thereby weakening the commercial banks because they have not completely succeeded in getting regulators to allow them full entrance into the newly-widening securities channel. ${ }^{85}$

\section{E. Other Regulatory Impediments}

Since my purpose here is not to catalog unending legal impediments but only to show that the foreign systems would fail under American law, even one show-stopper restriction-McFadden, for example-suffices. In addition, the other major U.S. financial intermediaries-insurers, mutual funds, and pensions-have historically also been precluded from taking big financial positions in America's largest firms, preclusions consistent with the general thesis that the structure of the large firm is highly sensitive to the structure of

83. Cf. Ramseyer, supra note 78 , at $23-31$.

84. See Bruce Kasman \& Anthony P. Rodrigues, Financial Liberalization and Monetary Control in Japan, FED. RESERVE BANK N.Y. Q. REV., Autumn 1991, at 28, 29-31 \& n.4. Determining which is the "natural" base-American securities markets or Japanese banks-is difficult because America has burdened big banks while Japan has subsidized them. Nationwide banking seems a natural baseline, which only America eliminated, thereby reducing nonsecurities alternatives for large firms and facilitating the development of a securities market. If large American banks had existed, they might have made large loans and stock investments that in America had to flow through the securities market.

85. This discussion of forcing funds through banks is offered as a comparison with Japan, not as a policy recommendation. 
financial intermediaries, which in turn is highly sensitive to law. For half a century, major American insurers were prohibited from owning any stock, ${ }^{86}$ and mutual funds have been discouraged from acquiring influential blocks of stock ${ }^{87}$ Pension funds, while not formally prohibited from buying influential blocks', are controlled by managers of large firms who discourage such influence, rather than by managers of financial intermediaries who might encourage it. ${ }^{88}$

Securities laws historically have made communication among stockholders costly. Until last year, ten stockholders who merely spoke with one another about corporate events and managers risked violating proxy rules. ${ }^{89}$ Interbank (and interfinancier) communications among banks with large blocks of stock could have been construed as a proxy solicitation, thus necessitating a public filing with the Securities and Exchange Commission. Under state antitakeover laws, group votes are generally sterilized, trigger poison pills, or violate "control share" statutes. 90

Why don't U.S. firms participate directly in each other's governance by holding large blocks of each other's stock? Although there are no explicit prohibitions, operating firms are poorly suited to hold large blocks of stock because they usually prefer to deploy their capital for other purposes. Even in Japan, where industrial cross-holdings play a role, financial intermediaries hold two-thirds of the blocks, while industrial firms hold only one-third of them. Moreover, American industrial cross-holdings would be taxed. In the 1930's Congress passed a dividends received tax explicitly to discourage such corporate complexes. ${ }^{91}$

Why did the United States adopt so many impediments to institutional voice in corporate governance? American populism-a popular mistrust of powerful private financial intermediaries-and American interest group jockeying yielded many of the restrictions. While German and Japanese politics display some similarities-particularly popular distrust in Germany and interest group infighting in Japan-foreign politics has been different. Different political paths yielded different financial institutions, and different financial institutions yielded different corporate structures. We shall return to consider these historical and political influences in Part IV. Before we do, however, we

86. Mark J. Roe, Foundations of Corporate Finance: The 1906 Pacification of the Insurance Industry, 93 COLUM. L. REV. 639 (1993).

87. Mark J. Roe, Political Elements in the Creation of a Mutual Fund Industry, 139 U. PA. L. REV. 1469,1470 (1991).

88. See generally Roe, Modern Corporation, supra note 57.

89. See Black, supra note 9, at 537-41. New proxy rules, adopted on October 15, 1992, reduce, but do not eliminate, some of these possibilities.

90. See, e.g., Cullen v. Milligan, 578 N.E.2d 123 (Ohio 1991) (applying Ohio control share statute); Atlantis Group, Inc. v. Alizac Partners, No. 1:90 CV-937, 1991 WL 319384, at*1 (W.D. Mich. Aug. 27, 1991) (applying Michigan control share statute).

91. Roe, supra note 87 , at 1478 . Today the tax rate is about $10 \%$ of the dividend. The tax also discourages bank cross-holdings. 
must first assess a preliminary economic argument-that financial evolution necessarily yields a fragmented financial system. After all, if fragmentation is inevitable, we need not bother with the difficult task of hypothesizing whether intermediary participation in flattened corporate structures is on balance advantageous. Over time entropy will prevail, the argument goes, and ownership will fragment.

\section{FinANCIAL EVOlUtion IN GERMANy AND JAPAN?}

In this Part, I briefly examine economic evolution here and in Germany and Japan. While it is possible that financial evolution inevitably fragments ownership of the large firm, the evidence suggests that intermediaries' economic evolution is uneven and that fragmentation is not economically inevitable. The financial markets in Germany and Japan may not be moving toward full American-style securities markets with fragmented ownership; there is as much evidence of stability and concentration abroad as there is of fragmentation. It is equally plausible that our markets and ownership forms are approaching-weakly and unevenly-the more concentrated structures of Germany and Japan. Thus, we should re-interpret recent trends in the United States toward ownership concentration and institutional voice as the delayed results of the repeated historical suppression of powerful American financial intermediaries.

\section{A. The Evolutionary Argument}

Do Germany and Japan lag behind America's financial evolution? In time, the argument runs, finance liquifies and disintermediates. Securitization, diversification, and fragmentation of stockholdings erode big institutional blocks. Powerful intermediaries wither as stock disperses into small blocks held by individuals and weak institutions. Commercial paper replaces bank loans, eroding banks' interest in holding stock in their former loan customers. Hence, the universal problems of financial organization eventually compel dispersed ownership, managerial agency problems, and structures for dealing with agency costs similar to those in America. According to the evolutionary argument, then, the powerful financial institutions in Germany and Japan are only temporary and will ultimately come to resemble U.S. financial institutions, which represent the highest form of financial development. Inevitable economic forces will erode the presence of institutions at the top of foreign firms.

I question this view. True, German banks' boardroom power is under stress. ${ }^{92}$ And the Japanese main bank system is under severe stress from

92. See infra notes 123-129 and accompanying text. 
increased securitization of debt in Japan, the internationalization of financial markets, Bank of International Settlements capital standards that penalize stock ownership, the increase in Japanese corporate retained earnings, and a sinking Japanese stock market. I suspect that key features of the main bank system-those involving bank control of large firm new financing-will not survive and may already be gone. Nevertheless, German banks' big stock holdings have increased, not decreased, over the last twenty-five years, and Japanese bank ownership of large Japanese firms has been rock-solid at roughly $20 \%$ of the outstanding shares for the past twenty-five years. These trends belie the inevitability of fragmentation. And, as I discuss in Part IV, if there is financial evolution, political forces are playing a role.

\section{B. Problems with the Evolutionary Argument}

Securitization and economic change are indisputable facts. Their effects, and the possibility of substitutes, are in doubt.

\section{Securitization}

Securitization produces three threats to German universal banks and Japanese main banks. First, as debt securitizes, commercial paper and bonds replace bank loans, so commercial banks' influence as lender declines. Second, as banks make fewer loans to their customers, they could become less interested in holding their customers' stock; if they sell the stock, commercial banks' influence as stockholder declines. Third, as liquid securities markets develop, institutions fragment their stock holdings and, the argument would run, no financial institution, and certainly no bank, would want to hold a big block of stock; institutional influence through big blockholding declines.

The first threat is real. As some debt has securitized, banks' influence has declined. But must banks' power from stock wither as debt increasingly securitizes $?^{93}$ Does the realization of the first threat to bank power-declining loans-demand realization of the second threat-declining stock? The evidence suggests not. As Table VI shows, German bank ownership of large blocks of stock in the largest firms has increased during the past twenty years, and, as seen in Table II, Japanese bank ownership of stock in large firms was stable throughout the 1980 's. ${ }^{94}$ Those predicting fragmentation may well have

93. Banks are a conduit between savers and borrowers. Depositors place money in banks, and the banks then lend those funds, but are obligated to repay the deposits even if the loans are not repaid. Yet securities markets are increasingly assuming these functions. Depositors who used to deposit their money in the bank now lend the money to corporations without using banks as intermediaries. To bypass the banks, providers of short-term funds buy commercial paper from industrial corporations and providers of long-term loans buy bonds.

94. Between 1977 and 1992 , the banks sold a modest $1 \%$ when Japan lowered the maximum bank holding from $10 \%$ to $5 \%$ of the outstanding shares of stock, to take effect in stages through 1987 . The sell- 
conflated an inevitable weakening of fractional reserve banking-the first threat-with a weakening of large stockholding institutions. The first is likely and the current trend the world over; the second may not at all be likely and is certainly not yet supported by the German and Japanese evidence.

\author{
TABLE VI. German Banks 5\% or Greater Positions \\ in the 100 Largest Firms ${ }^{95}$
}

\begin{tabular}{|c|ccccccccc|}
\hline Year & 1972 & 1975 & 1978 & 1980 & 1982 & 1984 & 1986 & 1988 & 1990 \\
\hline Number of Positions & 20 & 21 & 25 & 26 & 25 & 29 & 30 & 30 & 33 \\
\hline
\end{tabular}

A common misconception is that German bank influence comes only from credit. Americans are so inured to the separation of banks from commerce that we tend to view credit allocation as the banks' primary means of influence. Although German banks' absolute power over credit has already withered for the large German firms, ${ }^{96}$ their stock-based control over the proxy system has

off stabilized in 1985 . This $1 \%$ sell-off equals the bank-owned stock above $5 \%$ in 1977 , as Table XII shows. Law and Japanese politics, not securitization, best explain the sell-off. Japanese Federal Trade Commission, The Actual Conditions of the Six Major Corporate Groups 2 (Aug. 1 1989) (unpublished report, on file with author).

Now that Japanese stock prices are depressed, another sell-off has been predicted (but not observed). This situation mirrors the one in which stock prices were high and a sell-off was also predicted. See Larry Zoglin, Stable Cross-Holding of Shares Likely to Withstand Pressures, JAPAN ECON. J., June 21, 1986, at 7. Tables III and XI show that a sell-off did not occur. In general, though, a sell-off at high prices seems more plausible then one at low prices. When prices are high, insiders reap a gain by selling, but when they are low, insiders incur a loss.

95. Source: JÜRGEN BÖHM, DER EINFLUSS DER BANKEN AUF GROSSUNTERNEHMEN 238 (1992). Nor is this a repositioning of stock. Banks' direct ownership of public companies has been rising:

TABLE VII. German Banks' Ownership of Public Companies

\begin{tabular}{|c|cccccc|}
\hline Year & 1960 & 1970 & 1980 & 1985 & 1988 & 1990 \\
\hline $\begin{array}{c}\text { Percentage of Public Company } \\
\text { Stock Owned by Banks }\end{array}$ & $6 \%$ & $7 \%$ & $9 \%$ & $8 \%$ & $9 \%$ & $10 \%$ \\
\hline
\end{tabular}

Source: Julian Franks \& Colin Mayer, Corporate Control: A Synthesis of the International Evidence 24 (Nov. 1992) (unpublished manuscript, on file with author) (using Deutsche Bank data).

The reader will recognize a discrepancy between Table VI and Table VIII, which shows twenty-two $5 \%$ blocks. Table VI seems to include blocks in the top German banks, but Table VII does not. The key issue here is that the number of big block positions is increasing not decreasing.

96. Michael H. Best \& Jane Humphries, The City and Industrial Decline, in THE DECLINE OF THE BRITISH ECONOMY 223, 224 (Bernard Elbaum \& William Lazonick eds., 1986). Since 1970, retained earnings constitute $84 \%$ of new German corporate financing-about the same level as in America. CLAUDIO BORIO, LEVERAGE AND FINANCING OF NON-FINANCIAL COMPANIES: AN INTERNATIONAL PERSPECTIVE, 15 (Bank for International Settlements Economic Papers, No. 27, 1990).

Of the (small) amount of capital projects that are financed externally (i.e., without relying on retained earnings), in Germany, $70 \%$ is provided by the banks while in America only $25 \%$ is provided by the banks. Randall J. Pozdena, Commerce and Banking: The German Case, WEEKLY LETTER (Fed. Reserve Board of S.F., Cal.) Dec. 18, 1987, at 2; see also J.S.S. EDWARDS \& KLAUS FISCHER, BANKS, FINANCE AND 
not, and their big blockholdings are increasing. ${ }^{97}$ True, since Japanese credit control has weakened only in recent years, we cannot be sure Japan will take the same path as Germany did. Because bank financing is higher in Japan than in Germany, the banks' influence as lender-whose decline constitutes the first threat-will decrease as competing financing channels open. But if Japanese banks can enter the securities channel, the first threat may not be devastating; such entry would not only enable them to keep influence via debt, albeit securitized debt, but would enable them to retain a weakened credit-based motivation to hold stock.

The third threat is that securitization would necessarily destroy big blocks. In theory, this is false..$^{98}$ Debt and stock may disintermediate from direct ownership by banks and reappear in a complex intermediary that combines mutual funds, insurance funds, brokerage stock, and pensions. To some extent, this combination already exists in Germany. Deutsche Bank combines several of these, and the new Dresdner-Allianz Insurance combination combines several others. ${ }^{99}$ Stock-based power seems to be increasing in Japan, as a substitute for credit-based power. Japanese banks now dispatch more directors to industry, not fewer, ${ }^{100}$ and Japanese insurers are becoming more assertive. ${ }^{101}$ Furthermore, the extent of the disintegration depends upon Japan's Glass-Steagall Act and the absence of strong nonbank intermediaries. Without Glass-Steagall, Japanese banks might become brokers or sponsor mutual funds; disintermediated debt and stock could consolidate and be held by brokers and mutual funds affiliated with banks. ${ }^{102}$ In fact, commercial

INVESTMENT IN WEST GERMANY SINCE 197021 (Centre for Economic Policy Research Discussion Paper Series No. 497, 1991) (arguing that German stock corporations "relied hardly at all on bank borrowing as a source of finance for investment over the period 1971-85, and instead were largely internally financed").

97. EDWARDS \& FISCHER, supra note 96.

98. The evolutionary theorists mistakenly offer this syllogism:

(1) Banks are the intermediaries with governance influence in Germany and Japan.

(2) Banks' core function is to lend money.

(3) Securitization and retained earnings marginalize banks' credit.

(4) Therefore, as securitization reduces bankers control over credit, financial institutions' influence must weaken.

Statements (1), (2), and (3) are true, but, due to substitutes and stock-based power, (4) is not.

99. See infra note 115 and accompanying text.

100. Japanese Federal Trade Commission, supra note 94, at 2; cf. Kaplan \& Minton, supra note 36, at 20 (noting more bank interventions as stock performance weakens). Whether bank monitoring should be interpreted as the intervention of residual stockholder, or of a large creditor, or as intervention arising from contractual relations in the production process, is discussed briefly infra notes 194-198 and accompanying text and in detail in Ronald J. Gilson \& Mark J. Roe, Understanding the Japanese Keiretsu: Overlaps Between Corporate Governance and Industrial Organization, 102 YALE L.J. 871 (1993).

101. KESTER, supra note 31, at 216 (Japan's largest insurer, Nippon Life, says it used to be passive as a shareholder but is now beginning to assert its position as an investor where it affects the return on investment). Although insurers have increased their stockholdings, partly to pick up the stock that banks were forced to sell when the lid was lowered from $10 \%$ to $5 \%$, they are now reaching the limits of their legal (and perhaps financial) ability to hold stock. JACK MCDONALD, ORIGINS AND IMPLICATIONS OF CROSS-HOLDINGS IN JAPANESE COMPANIES 9 (Graduate School of Business, Stanford University Technical Note No. 79, 1991).

102. Even if bond debt replaces bank debt, if bank affiliates hold that debt, elements of the main bank system would be recreated, although in muted form. Indeed, as the Japanese Glass-Steagall Act has been 
bank evolution to a more complex intermediary is budding in Japan, and the Ministry of Finance has proposed allowing banks to buy, sell, trade, and form mutual funds for commercial paper and bonds. Investment companies and funded pensions are expected to flourish. ${ }^{103}$ Hence, Japanese banks' power in corporate governance will continue to erode only if they lack the political power to get Japan's version of Glass-Steagall rolled back. To date they have been only partly successful. ${ }^{104}$

Even if German and Japanese banks sold their stock, someone would own the stock that banks now own. Dispersed individuals might hold the stock in small blocks, although that is unlikely; small institutions might buy small blocks of the stock, and that is possible. Or, new concentrations might arise, such as larger German banker-broker networks, or powerful mutual funds, or expanded versions of the Japanese system of customer-supplier crossownership. Finally, the Japanese banks might "sell" their stock to affiliates, if the banks induce repeal of the Glass-Steagall Act. ${ }^{105}$

\section{Autonomy}

The evolutionary paradigm for Germany and Japan posits that powerful intermediaries develop industry, and their power then erodes due to the securities market's disintegrating effects. If there were powerful intermediaries resembling the universal banks or the main banks in America's past, and they weakened as they were displaced by a superior securities market, then the argument that foreign nations now lag behind America would be more convincing. We could predict a single path for financial fragmentation. But powerful stockholding intermediaries were generally absent in American history. We should not view the evolution of financial systems as following a single economic path, in which every system ultimately converges on highly diversified portfolios, fragmented ownership, and weak intermediaries.

Details from American history are suggestive. In nineteenth-century New England, entrepreneurs tightly bound their operating firms with banks. Similarly, the Japanese zaibatsu families bound their industrial firms with banks, and Deutsche Bank in its early history helped finance new companies like Siemens and AEG. The foreign banks grew into big national financial

rolled back slightly, the Japanese banks have moved into the debt securities market. MASAHIKO AOKI, INFORMATION, INCENTIVES, AND BARGAINING IN THE JAPANESE ECONOMY 141 (1988).

103. ROSENBLUTH, supra note 79, at 75; Kanda, supra note 81 , at 569.

104. Japan Will Allow Overlap of Banks, Brokerage Firms, WALL ST. J., Dec. 18, 1992, at A4 (describing slow, partial erosion of Japanese Glass-Steagall Act).

105. The result is likely to depend on the future nature of business. The Japanese managerial style, labor relations, and rapidly changing product cycle have favored today's ownership structure. If these underlying business features change, the old structures may become less useful. Cf. Masahiko Aoki, Toward an Economic Model of the Japanese Firm, 28 J. ECON. LIT. I (1990). A plausible prediction is that some firms, like those whose business is easily understood by investors in the securities market, will securitize while others will not. 
institutions, the American banks did not, and the ties between the American entrepreneurs and their local banks withered. Why? As economic opportunities shifted from New England to the national economy, the New England banks could not get good information about distant firms, and the bankers could participate in the national economy only as passive buyers of short-term commercial paper. ${ }^{106}$ "[T] he legal prohibitions against branch banking and the distance between economic centres produced ... relatively small, not very closely connected, short-term markets. . . . Because of the prohibition on interstate branching, a national market had to await the development of a ... commercial paper [market]." ${ }^{107}$ Entrepreneurs affiliated with banks could go national, as economic opportunities certainly did, but the bankers, due to interstate branching restrictions, could not. ${ }^{108}$

Recent German trends and Japanese economic history also undercut the argument that their ownership structures must evolve toward the American model. First, German managers have behaved inconsistently toward banker control of the proxy system. Many German companies have limited the voting of outsiders, not to undercut the power of bankers, but to thwart hostile takeovers. ${ }^{109}$ Managers, it seems, choose to have large, sometimes influential (but not dominating) blocks of stock controlled by financial intermediaries when they fear a hostile takeover. Second, Japanese cross-holdings are a recent phenomenon. Before World War $\Pi$, the zaibatsu combined banks and industrial firms, under family ownership, with banks as the weaker player. During World War II, the Japanese government munitions planners weakened the authority of the family owners. After World War $\Pi$, the American occupation broke up the zaibatsu and distributed stock widely. Eventually enough stock fell into bank hands to give rise to banker authority. During the 1960's cross-holdings accelerated for two reasons. Many Japanese managers feared that joint ventures with American companies would end up with the American firm owning the Japanese firm; they wanted a lot of stock placed in safe, friendly Japanese hands. In addition, in the late 1960's corporate Japan feared that the Japanese

106. Naomi R. Lamoreaux, Information Problems and Banks' Specialization in Short-Term Commercial Lending: New England in the Nineteenth Century, in INSIDE THE BUSINESS ENTERPRISE: HISTORICAL PERSPECTIVES ON THE USE OF INFORMATION 161, 180 (Peter Temin ed., 1991) ("IN]ow that firms could issue their IOUs through note brokers, who would market them to banks and financial intermediaries across the country, banks lost their ability to assess a customer's total indebtedness.") (emphasis added). Since banks have an advantage in information gathering, one wonders why bankers ceded the profits to investment brokers, other than because, unlike banks, brokers could market notes throughout the country.

107. Lance E. Davis, The Capital Markets and Industrial Concentration: The U.S. and U.K., A Comparative Study, 19 ECON. HIST. REV. (2d ser.) 255, 260 (1966).

108. Massachusetts (like other states) also prohibited its banks from lending to out-of-state firms (although it apparently didn't stop them from buying securitized commercial paper). Lance E. Davis, Capital Immobilities and Finance Capitalism: A Study of Economic Evolution in the United States 18201920, 1 EXPLORATIONS IN ENTREPRENEURIAL HIST. 88, 99 (1963). Regulation sufficiently explains the result; whether it was necessary, we cannot know.

109. BAUMS, supra note 16 , at 10 . 
government would sell stock from financially-distressed brokerage houses; this risk and depressed stock prices created fear of American-style takeovers, which cross-holdings, including holdings by banks, would deter. The cross-holdings that are at the core of modern Japanese corporate governance are a post-World War II institution. ${ }^{110}$ The bank-centered keiretsu succeeded the old-line zaibatsu. Then, during the postwar decades, newly rising big firms independent of the traditional keiretsu have chosen the same concentrated institutional ownership. ${ }^{111}$

American managers might have encouraged strong financial intermediaries to enter the boardroom had they feared similar uncertainties. If American managers had not been so successful in defeating takeovers with poison pills, legislative antitakeover barriers, and the luck of a rising stock market, they might have invited intermediaries into corporate boardrooms. They may well have disliked powerful stockholders but probably detested hostile takeovers more. Managers and financiers could have formed an irrepressible political coalition to undo existing American legal barriers to a close nexus between finance and industry. ${ }^{112}$

Although I cannot rely on this "might-have-been" claim to prove that evolution into fragmented ownership and liquid securities markets is not inevitable, I can point to a few targets that sought big blockholders to protect themselves from takeovers. ${ }^{113} \mathrm{Had}$ U.S. managers not defeated takeovers in other ways, big blocks might have been management's next defense. Similarly, after the prospect of American-style takeovers arose in Germany, ${ }^{114}$ Dresdner Bank, Allianz Insurance Company, and Hoechst, a huge chemical firm, developed major cross-shareholdings among themselves and other German

110. MCDONALD, supra note 101 , at 1 .

111. See Table XI (some of the 14 largest firms, shown in Table III, overlap with the new "independents" shown in Table XI). Some see the new Japanese large firms that have arisen outside the old-line successors to the zaibatsu as a sign of institutional ownership's erosion. Coffee, supra note 37, at 1301-02. Since, however, the new firms' institutional ownership structure is identical to that of the old-line firms, their rise does not show a decay in institutional ownership. Moreover, because the new firms are a tad more profitable than the old ones, some conclude that cross-ownership is deleterious to shareholders. But since the new firms have the same ownership structure (and frequently have founding families with some stock as well), institutional ownership structure is not a relevant variable.

112. Cf. Carol J. Loomis, The New J.P. Morgans, TIME, Feb. 29, 1988, at 44 (listing LBO's with financiers on board). Many LBO's dealt with managers' misdirected use of free cash flow to build empires, a problem Japanese firms are only now beginning to face. Thus, the point here is not that LBO's and institutional ownership are perfect equivalents, but that LBO's flatten authority by bringing financiers into the boardroom, thus calling into question the notion that economic evolution inevitably drives large firms toward fragmented ownership.

113. Vineeta Anand, Warren Buffett Effect: A Quick Jump in Stock Prices, Aug. 23, 1991, at 8, 8 ("In September 1987, Buffett infused $\$ 700$ million into Salomon, then facing a takeover threat from Ronald Perelman. He was rewarded with two seats on the board ..."); David A. Vise, CBS Loses \$114 Million in Quarter, A Record, WASH. PoST, Nov. 13, 1985, at E1, El ("Loews Corp. Chairman Laurence A. Tisch was elected to the CBS board ... [Loews' stock ownership] is expected to bring stability to a company that has been the subject of intense takeover speculation...").

114. The most prominent of these was Pirelli's multiyear siege of Continental, the large German tire manufacturer. See Andrew Joncus, Continental AG Shareholders Deliver Pirelli Another Blow, WALL ST. J. EuR., July 6, 1992, at 4. 
industrial companies. ${ }^{\text {II }}$ The Japanese construction after World War II of new vertical keiretsu around the firms that emerged independent of the old-line keiretsu and the acceleration of cross-holdings in the 1960's are similar. Thus, features of all three nations-the recent German keiretsu-style cross-ownership, the fact that Japanese cross-ownership is a post-World War II institution, and the scattered American antitakeover blocks-all tend to contradict the inevitability of fragmentation.

\section{American Evolution}

Commentators assert that Germany and Japan will ultimately evolve to American-style diffuse ownership. Perhaps they will. Japanese main banks are under great financial pressure, which could lead them to sell stock to raise cash; without affiliated allies such as bank-controlled trusts, mutual funds or pensions to relieve some of the pressure and hold some stock, it is difficult to see how the Japanese system can continue in its present form. Yet, unnoticed is the prospect that U.S. firms may be evolving-weakly and unevenly-toward the German and Japanese style of ownership. U.S. intermediaries have steadily taken on new functions. The next natural evolutionary stage in American corporate finance might be the entrance of financial institutions into corporate boardrooms, ${ }^{116}$ perhaps by electing directors whose loyalty runs to them, not the managers. Indeed, Berkshire Hathaway, an insurer whose big blocks and legal authority to buy them are recent acquisitions, already vaguely resembles the German universal banks and Japanese main banks. And, leveraged buyouts, although different in key ways, also increase the voice of institutions in corporate governance. ${ }^{117}$

True, the five largest American holders rarely own much more than 5\% of the twenty-five largest American firms, and only a few approach the level of German ownership and voting and of Japanese concentration. ${ }^{118}$ Nevertheless, some institutions have been active in corporate governance-making shareholder proposals, seeking to elect directors, and

115. Hans Otto Eglau, Allianz/Dresdner Bank-Vermachtet und Verschachtelt [Empowered and Interconnected], DIE ZEIT, Aug. 16, 1991, at 19. The holdings were also tax-driven. Dresdner is Germany's second-largest bank, Allianz its largest insurer, and Hoechst the sixth-largest industrial firm. Lufthansa and Bayer are expected to join. The cartoon accompanying this article suggests popular reproach to the concentration of private economic power by showing an Allianz-Dresdner octopus gobbling up German industry. Id. Banks are hubs of new industrial networks elsewhere in Germany, with cross-representation of network members on boards. Kirsten S. Wever \& Christopher S. Allen, Is Germany a Model for Managers?, HARV. Bus. REV., Sept.-Oct. 1992, at 36, 42.

116. Cf. Robert C. Clark, The Four Stages of Capitalism, 94 HARV. L. REV. 561 (1981).

117. Gilson \& Roe, supra note 100, at 902-04 (discussing similarities and differences); Jensen, supra note 9 , at $65-66$ (noting similarities).

118. The rarities are mainly the large blocks held by Berkshire Hathaway. Coca-Cola had a fiveshareholder concentration level of $20 \%$, as might a Japanese firm, but due to legal anomalies-holdings vy Berkshire Hathaway, an insurance holding company operating outside the norm, and a bank exempt from the Bank Holding Company Act's general provisions. 
petitioning the Securities and Exchange Commission to loosen restraints on their activity. ${ }^{119}$ If these trends continue and expand to include holding big blocks of stock, U.S. corporate ownership may someday begin to resemble the German and Japanese systems.

American aggregate concentration is already a pale imitation of foreign corporate structures. The largest twenty-five institutional investors vote, on average, $16 \%$ of the stock of the twenty-five largest American corporations. ${ }^{120}$ While this is a far cry from the three institutions in Germany that vote $40 \%$, or the five in Japan that vote $20 \%$, it shows that U.S. large firm ownership is no longer that of an atomized Berle-Means corporation. And shareholder concentration for the next tier of U.S. firms is even greater, approaching the level of concentration in Japan. Since many of these secondtier stockholders are mutual funds and pensions, we can see that the U.S. trend over the past century has been, first, a suppression early in the century of the "basic" intermediaries (banks and insurers), followed by an emergence in the 1990's of other institutions (mutual funds and pensions) as substitutes.

\section{Economic Evolution and the Cost of Capital}

A meta-economic explanation, atop the classical one, helps explain the different laws that influence corporate structures. Societies afflicted with capital scarcity have reason to organize firms differently than societies with more abundant capital. Historically, capital and natural resources were relatively abundant in the United States. In Germany and Japan, on the other hand, capital was scarce in the post-World War II decades. ${ }^{121}$ Whenever a resource is relatively scarce, people and institutions are willing to pay to monitor its proper use. In the American southwest, water is scarce and metered, and its use is a serious legal issue; elsewhere, where water is abundant, its use is unmetered and unregulated. Likewise, when capital became relatively scarcer in the United States, as reflected in the rising interest rates of the 1980's, more mechanisms to monitor its deployment came forth; and when Japanese success led to relatively greater stores of capital in the 1990's, monitoring mechanisms may have declined. ${ }^{122}$

119. E.g., Randall Smith, Calpers Mulls Stakes in Funds Seeking Changes in Firms' Strategy, Governance, WALL ST. J., Dec. 31, 1992, at A3.

120. Brancato et al., supra note 10 , at tbl. 7.

121. Although the cost of capital that Japan "posted"-its interest rate-have made its capital seem cheap, in fact bank rationing effectively reflected a capital scarcity after World War II.

122. This fact could revive the evolutionary argument; one could argue that as economic tasks change, the level of monitoring changes. For example, German and Japanese corporate structures may be particularly adept at managing new investments and thus may be most suitable during a sustained general economic expansion. But in mature economies some firms expand while some contract, making a mixed
system suitable. 
Thus, as it turns out, current data indicate that fragmentation is not yet economically inevitable; there is as much (or more) evolutionary concentration here as there is evolutionary fragmentation there.

\section{POLTTICAL EVOlUtion IN GERMANY AND JAPAN?}

Even if German and Japanese stock ownership were fragmenting (and American ownership were not concentrating), the incompleteness of current corporate theories would persist. We would need to determine the degree to which politics in Germany and Japan is inducing financial evolution in those countries. Financial fragmentation could be inherent in twentieth-century democracy, rather than merely inherent in American democracy as I hypothesized earlier. Both foreign nations' political and corporate histories could have evolved together: large industry emerged abroad when nondemocratic governments kept fragmenting forces in check; indeed, today's foreign democracies affect corporate structures, but in ways and degrees different from that which occurred in the American past.

Although my goal here is not to provide a definitive history of how German and Japanese politics affected their corporate structures-I commend that task to those with the requisite knowledge and language skills, which I lack-even a cursory inquiry by a nonexpert shows that political forces are at work in Germany and Japan, shaping the governance of the large firm. Indeed, how could it be otherwise? The movement of capital from savers to firms has to attract political attention and affect either public opinion or interest groups, whose interactions with political institutions will influence the organization of financial institutions, which in turn will affect the ownership structure of the large firm.

\section{A. German "Populism"}

Deutsche Bank reviews whether to allow its employees to chair an industrial firm's board, and some German banks have sold directly-held stock. Is this part of an economic evolution? Perhaps so, but the German banks are under intense political pressure ${ }^{123}$ from forces not unlike those in the United States that historically disabled powerful financial intermediaries. German

123. John Dornberg. The Spreading Might of Deutsche Bank, N.Y. TIMES, Sept. 23, 1990, at 28 (reporting impulse among Social Democrats and market-oriented Free Democrats to reduce banks' power); Ferdinand Protzman, Mighty German Banks Face Curb, N.Y. TIMES, Nov. 7, 1989, at D1, D1 (reporting that "parliament has begun studying steps to limit the banks' shareholdings, their seats on boards and their influence in corporate decision-making."); Terence Roth, West German Banks Face Threat of Reduced Influence in Industry: Bonn Will Consider Rules to Curb Their Holdings and Seats in Boardrooms, WALL ST. J., July 18, 1989, at A20, A20 (reporting that "[w]ith main stream politics coming into play, bankers worry that they'll be forced to sell parts of their sizable equity holdings in West German industry, thus threatening their dominant position in the country's equity markets."). 
politicians claim that the bankers' power clashes with the German "social order."124 Parliamentary reports attack the banks. Members of Parliament desire to limit "the percentage of equity a bank could maintain in a nonbank enterprise and cut the number of supervisory board positions a bank executive could hold," 125 and look to the American Bank Holding Company Act for guidance. ${ }^{126}$ Managers are said to want to get bankers out of supervisory boards, although they hesitate to say so publicly. ${ }^{127}$ Executives in Germany's mid-sized firms oppose bankers' influence and want laws prohibiting German banks from owning nonbank stock. ${ }^{128}$ Fear of powerful banks "form[s] the backdrop of many economic and political discussions. Conducted in the press, on radio, and on television, among scholars, and, most importantly, political groups, these discussions use emotion-laden terms such as 'bankocracy,' 'dominion of finance capital,' and similar verbal symbols."129

The banks have bowed to this political pressure, at least verbally. ${ }^{130}$ After German politicians lit a storm of political protest in the region where a bank-propelled takeover target operated, the bankers lowered their public profile. ${ }^{131}$ Moreover, Deutsche Bank, Germany's largest bank, has stated that

124. Hans-Jacob Krümmel, German Universal Banking Scrutinized: Some Remarks Concerning the Gessler Report, 4 J. BANKING \& FIN. 33 (1980); see also Der Herr des Geldes [The Money Man], DER SPIEGEL, Mar. 13, 1989, at 20; Die Geheimräte der Nation [The Nation's Secret Councill, INDUSTRIEMAGaZIN, Apr. 1987, at 27; Horst Greiffenberg, Die Macht der Banken [The Power of the Banks], VerbRAUCherPolitische HeFTE, Dec. 1987, at 85; Jörg Huffschmid, Demokratische Altemativen der Bankpolitik [Democratic Alternatives for the Politics of Banking], VERBRACHERPOLITISCHE HEFTE, Dec. 1987, at 111; Zwischen Bonn und Banken: Finanzdiplomat Hermann Abs [Between Bonn and the Banks: Financial Diplomat Hermann Abs], DER SPIEGEL, Nov. 3, 1965, at 10.

125. Dornberg, supra note 123, at 28.

126. Wolfram Eckstein, The Role of the Banks in Corporate Concentration in West Germany, 136 ZEITSCHRIFT FÜR DIE GESAMTE STAATSWISSENSCHAFT [J. INSTITUTIONAL \& THEORETICAL ECON.] 467, 480 (1980) (Eckstein was Secretary General of the Monopoly Commission); see also Johannes Köndgen, Duties of Banks in Voting Their Clients' Stock 11 (July 1992) (unpublished conference paper, on file with author) (discussing parliamentary hearings of the committee for economic affairs).

127. Otto Graf Lambsdorff, Das Machtgeflecht der Banken Lichten, FRANKFURTER ALLGEMEINE ZEITUNG, Aug. 22, 1989, at 10 (leading German politician says senior managers privately tell him that they wish to see banker power reduced). When takeovers became a real possibility, however, German managers reconsidered.

128. Bundersverband mittelständischer Wirtschaf, Expose zur "Macht der Banken" 9 (Apr. 24, 1991) (unpublished results of survey conducted by German association of mid-sized businesses, on file with author). Eighty-eight percent of the businesses favor restricting the banks. Obviously mid-sized business opposition could refiect interest group opposition to banker power.

129. H.E. Büschgen, The Universal Banking System in the Federal Republic of Germany, 2 J. COMP. CORP. L. \& SEC. REG. 1, 25 (1979).

130. Krümmel, supra note 124 , at 53 (stating that bankers "continue with their traditional tendency to elude public controversy by a flexible attitude and not to rise against the zeitgeist, even if they are convinced they have the better arguments"); Die FDP will die Mineralölsteuer erhöhen stärken, FRANKFuRTER AllgEmeine ZeITUNG, Aug. 19, 1989, at 11 (leading German politicians form working group to curb banker power and some expect the banks to understand that prudent self-limitation is necessary); Fusion doch ohne Beschluss zur Bankenmacht, FRANKFURTER ALLEGEMEINE ZEITUNG, Sept. 7,1989 at $17-18$.

131. "Once the [target's] employees protested the [proposed] deal, the politicians in southern Germany, where [the target] is based, began to send up a hue and cry [which caused Deutsche Bank to change its position and opposed the merger.]" Jackey Gold, M\&A Continental Style, FIN. WORLD, Mar. 5, 1991, at $37,37$. 
the political costs are too great to maintain high visibility in corporate governance-either as an owner or as a director. ${ }^{132}$ To dampen public protest, which German bankers may believe managers could use to get American-style legal restrictions, German banks have lowered their public profile and announced that they will not fight curbs on their control over the proxy machinery. ${ }^{133}$ While German banks do not seem to be withdrawing from stock ownership yet, they may well be starting to use their stock less aggressively. Political pressures, not just economic evolution, account for some of this laxness.

True, this German "populism" has historically been weaker than the American strain: "Germany has never known anything like the fear and resentment that monopoly used to arouse in the United States. . . . Many Germans find it difficult to believe that something growing up without order and control, like a competitive market, could not be improved by applying a little discipline." ${ }^{.134}$ In America, antibank sentiments combined with powerful interest groups-small bankers or managers, for example-to produce laws restricting large banks, giving deposit insurance to small banks, and protecting managers from takeovers. The restraints on German banks, in contrast, are informal and self-imposed, designed to avoid formal restrictions. Why doesn't Germany enact the formal restrictions anyway, if the popular sentiment and the interest group motivations are there? Relative weakness of the sentiment and motive is only part of the answer. Political structure and different formal limits are also important. The German political structure dilutes the political effect of both anti-big-bank popular opinion and anti-big-bank interest groups. German citizens vote for a party which, based on its percentage of the national vote, gets a proportionate number of Parliamentary seats. ${ }^{135}$ The party is more important than the candidate. Local bankers and managers (and their campaign contributions) play a less important role in German elections than they do in U.S. congressional elections. ${ }^{136}$

132. Role of the Financial Services Sector: Hearings Before the Task Force on the International Competitiveness of U.S. Financial Institutions of the Subcomm. on Financial Institutions Supervision, Regulation and Insurance of the House Comm. on Banking, Finance and Urban Affairs, 101st Cong., 2d Sess. 164-65 (1990). As of 1990, this statement is reflected more in Deutsche Bank's rhetoric than its action, insofar as concerns its ownership blocks in Germany's 100 largest firms, which have been increasing, not decreasing. See Table VI.

133. Friedrich K. Kübler, Institutional Owners and Corporate Managers: A German Dilemma, 57 BROOK. L. REV. 97 (1991). American institutional restraint is similar. California's huge state pension fund apparently fears that "an organized Calpers-backed attempt to force management changes could trigger a reaction that could curb the big fund's freedom to act independently," in a fashion similar to the restraints arising from the 1980's takeovers. Smith, supra note 119, at A3.

134. HeNRY C. WALlich, MainsPRings OF THE GERMAN ReVIVAL 136-37 (1955).

135. LeWIS J. EDINGER, WeSt GERMAN POLITICS 119-20, 149, 172 \& n.6 (1986).

136. Id. at 148 (stating that power of political parties "discourag[es] interest associations from supporting independent deputies and [strengthens] cohesion within the parliamentary parties. The leaders ... can use the threat of expulsion to keep dissidents in line ..."). 
Moreover, popular opinion and interest groups do formally shape the German boardroom and dilute the power of the German banks, through codetermination. It injects employees-white collar, blue collar, and unionrepresented-into the boardrooms of the largest German firms, now giving them half of the supervisory board's seats not due to private contract-making or purely economic evolution, but due to the way the German Parliament settled political conflict. Codetermination is a counterweight to capital-the historical origins of codetermination are rooted in the German Parliament's efforts to co-opt revolutionary forces after the German revolution of 1918. ${ }^{137}$ Parliament expanded codetermination thereafter, most recently in 1976 when it sought to pacify unions after a wave of strikes in the 1970 's. ${ }^{138}$ While I am unaware of a probing political analysis of Germany's expansion of codetermination in 1976, I doubt that either popular opinion concerning the banks or the interest group influence of the German unions was irrelevant. While American politics fragmented capital and labor, German politics brought them together in the boardroom.

Codetermination has three important effects on German corporate governance. First, codetermination makes powerful intermediaries more politically palatable in Germany than they have been in America, because the employees are in the boardroom as a counterweight.

Second, codetermination affects the mechanisms of corporate governance by, for example, impeding takeovers. In the 1980's the rise of a takeover market in America induced popular fears that takeovers would disrupt employment. Antitakeover laws were the result, making takeovers more difficult. German codetermination has a similar effect; takeovers that would disrupt employment are difficult because the shareholders can never capture the entire supervisory board.

Third, codetermination affects and changes corporate governance in the supervisory board. Obviously, it impedes powerful intermediaries from pushing for rapid organizational change that would disrupt employment. More generally, bankers know that a powerful supervisory board enhances the authority of the employees. My understanding is that the bankers have thus sought to weaken the supervisory board, the arena where the employees are, while hoping that the managerial board will act as the bankers wish, perhaps after direct consultation with the shareholding institutions. ${ }^{139}$

The rhetoric of banker withdrawal from the boardroom should be considered with codetermination in mind. What if banks feared that the governance task ahead in Germany is to tighten the belts and salary levels of highly-paid German workers? They might plausibly have concluded that the

137. Thomas Raiser, The Theory of Enterprise Law in the Federal Republic of Germany, 36 AM. J. CoMP. L. 111, 117 (1988).

138. Alan Hyde, A Theory of Labor Legislation, 38 BuFf. L. REv. 383, 41 1-12 (1990).

139. See supra text accompanying notes $29-30$. 
German political climate would not allow the bankers a visible role in firing employees or lowering their salaries. Prudence would dictate a lowered profile.

History helps explain the German boardroom and the powerful German banks in another way. After Bismarck unified Germany, he sought to develop German industry by creating great banks as engines of development. ${ }^{140} \mathrm{~A}$ statist political system facilitated a central bank that provided liquidity to the German banks' long-term investments. ${ }^{141}$ These banks naturally expected to oversee the investments made with funds they lent and thus involved themselves in corporate governance. Happenstance helped propel the banks' stock power. The newly unified German state taxed transfers of securities. Stock owners wanted to avoid the taxes; German banks held customers' stock in the banks' name and issued receipts to the retail owners. Then, when one customer sold stock to another customer, the banks argued that no taxable transfer occurred, because a bank was still the record owner. The taxing authorities agreed. Thereafter, stock owners preferred to deposit stock with bigger banks, which could best match customers' sales and purchases, ${ }^{142}$ thus giving banks control over the proxy machinery.

One last aspect of German political history is relevant. For the nineteenth and most of the first half of the twentieth century, democratic politics and its fragmenting tendencies could not affect German intermediaries because Germany was not a democratic nation. This is not to say that financial power necessarily clashes with a democratic political system-democracies have concentrated industries and can also have concentrated intermediaries-but it does mean that the democratic features fragmenting American financial institutions from the nineteenth century to today have had less time to affect German intermediaries.

Similarly, the history of German corporate governance is also partly a transmission of government directions through the bank regulators to the large banks, which implement the directions and get financial protection from the government. (Japanese and German corporate governance and regulation are somewhat similar in this respect.) This statist structure, while again not necessarily at odds with democratic politics in general, is at odds with

140. Alexander Gerschenkron, EConomic Backivardness in Historical Perspective 14-15 (1962).

141. Richard Tilly, Banking Institutions in Historical Perspective: Germany, Great Britain and the United States in the Nineteenth and Early Twentieth Century, 145 ZEITSCHRIFT FOOR DIE GESAMTE STAATSWISSENSCHAFT [J. INSTITUTIONAL \& THEORETICAL ECON.] 189-209 (1989). While bank-driven industrialization went forward in Germany, the Bank of England would not provide that kind of liquidity to British banks. Id. And due to Andrew Jackson's populist-inspired veto of the rechartering of the Second Bank of the United States, the U.S. in the nineteenth century had no central bank to provide bank liquidity, inducing them to shun long-term, illiquid investments.

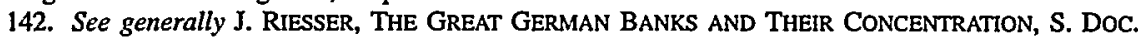
No. 593, 61st Cong., 2d Sess. 618-620 (1911). Riesser does not say whether the large banks lobbied for the tax result. The tax also stunted a German securities market. Richard H. Tilly, German Banking, 18501914: Development Assistance for the Strong, 15 J. EUROPEAN ECON. HIST. 113, 126-27 (1986). 
American democratic history and its impulse to fragment both concentrations of private economic power and centralized political power.

\section{B. Japanese Interest Groups}

Before World War II, the largest firms in Japan were the zaibatsu, which resembled the U.S. conglomerates of the 1960's but with family ownership, not public ownership, at the top. The zaibatsu were tightly connected to large banks but the family controlled the banks, which resembled. German universal banks in their use of long-term loans and equity positions. ${ }^{143}$ In 1943 , the Japanese military disrupted the system by ordering managers at munitions manufacturers to follow bureaucratic orders rather than shareholder directives and by directing munitions firms to choose a main bank to facilitate the auditing of wartime production. ${ }^{144}$ In 1948 , orders from the Supreme Commander, Allied Powers (SCAP) destroyed that corporate system with directives to break up the zaibatsu, to distribute their stock, and to prohibit bank ownership of big blocks of stock ${ }^{145}$ stemming from the "American belief that [democracy] not only required free elections, free speech, and due process, . . . but also the Glass-Steagall Act." ${ }^{\text {"16 }}$ Little else better shows law determining corporate structure than law imposed by a military dictatorship in 1943 or law imposed by an occupying military power in 1948.

SCAP prohibited Japanese banks from owning more than 5\% of another firm's stock, foreshadowing the American Bank Holding Company Act of 1956. But international politics—communism in China and war in Korea-and fear of Japanese domestic instability changed SCAP's primary goal from pacifying a defeated enemy to building a stable economic ally. So SCAP loosened its grip and decided not to pursue full fragmentation; it watched as Japan fostered close relations between finance and industry. During the following decades, stock relentlessly moved from individuals to banks and insurers, and cross-ownership bound finance and industry together.

Military directives - a type of law-deeply affected modern Japanese firms' ownership structure. The wartime Japanese military orders were practical in origin, but had some anti-capitalist ideology behind them. American occupation orders to force Glass-Steagall rules on the Japanese were not designed for the efficient operation of financial markets and the

143. William M. Tsutsui, Banking Policy in Japan 5, 11 (1988).

144. AOKI, supra note 82 , at 37 .

145. See generally J. Mark Ramseyer, Legal Rules in Repeated Deals: Banking in the Shadow of Defection in Japan, 20 J. LEGAL STUD. 91, 99-100 \& n.21 (1991) (comparing Japanese and U.S. banking regulation).

146. David G. Litt, Jonathan R. Macey, Geoffrey P. Miller \& Edward L. Rubin, Politics, Bureaucracies, and Financial Markets: Bank Entry into Commercial Paper Underwriting in the United States and Japan, 139 U. PA. L. REV. 369, 380 (1990). 
development of sound corporate structures, but to inculcate democracy, ${ }^{147}$ and the weaknesses now emerging in Japanese intermediaries are thus partly the delayed result of American democratic ideology. ${ }^{148}$ Oddly enough, American ideology also accounts for why the Japanese banks were not further weakened and were allowed to keep their large size. SCAP initially planned to dissolve the big banks and end nation-wide branching, but changed its mind. The American occupation bureaucracy thought that dissolving the zaibatsu was more important than dissolving the banks; since SCAP's antitrust analysis found that nine big banks and a fringe of smaller banks provided adequate competition, it thought the American model of financial fragmentation was inapt and thus forced the adoption of only Glass-Steagall but not McFadden. ${ }^{149}$

Although SCAP failed to fragment Japanese finance fully, it did break up the zaibatsu, limit bank stock ownership to $5 \%$, and segment commercial from investment banking. The incompleteness of financial fragmentation meant that, with subtlety, the Japanese could-and did-overcome the American-imposed Glass-Steagall rules-by keeping their banks big, by not adopting American passivity rules, and by channeling postwar credit through the banking system. This they did; with neither interest groups nor populism to block such efforts, the political task was easy. But now, in the 1990's, the banks are doing the heavy lifting in corporate ownership, and the weakening of banks puts the system under pressure. Some of these current stresses on banks are delayed reactions to restrictions imposed by U.S. occupation. ${ }^{150}$ Although Japan effectively repealed American efforts at fragmentation by channeling credit through banks, such a system cannot continue in the 1990's. Thus, the American-imposed segmentation pressures Japanese financial intermediaries today in ways it did not in prior decades. If this weakness leads banks to sell their stock, it could change the structure of ownership and authority in the large firm.

To preserve concentrated ownership, Japan could restructure its intermediaries, but fights among interest groups have stymied a complete

147. See, e.g., id. at $379-80$.

148. Occupation authorities in Germany imposed McFadden, although German authorities viewed it as unwise. When the occupation ended, Germany allowed geographically fragmented banks to merge, which they did. TsuTsui, supra note 143, at 55-56; Rolf Ziegler et al., Industry and Banking in the German Corporate Network, in NETWORKS OF CORPORATE POWER: A COMPARATIVE ANALYSIS OF TEN COUNTRIES 91, 106 (Frans N. Stokman et al. eds., 1985); Hans A. Adler, The Post-War Reorganization of the German Banking System, 63 Q.J. ECON. 322 (1949).

149. TsuTsul, supra note 143, at 41-43 (zaibatsu focus); id. 45-48, 63, 117 (incomplete fragmentation); $i d$. at 49-53 (SCAP plans to dissolve large banks); id. at 52, 119 (MacArthur decides banks are secondary).

150. Current Bank of International Settlements capital standards make bank stockholding more difficult. Japanese savers and corporate borrowers now have access to nonbank alternatives. Interest rates, previously depressed by the government, are reaching market levels. The American Structural Impediments Initiative seeks to fray the equity ties inside the keiretsu. 
restructuring. ${ }^{151}$ Securities firms see bank underwriting of securities by commercial banks as dangerous; ${ }^{152}$ commercial bankers, not surprisingly, see no danger. ${ }^{153}$ The best history of modern financial regulation in Japan sees interest group infighting, not arguments over the best means of achieving efficiency, as explaining the bureaucracies' slowness in deregulation:

[T]he walls that have divided various types of financial institutions since World War II still stand, because of the tenacity of entrenched interests. . . . City banks, for example, will be barred from making long-term loans in the Euroyen market until the long-term credit banks and trust banks receive suitable compensation, such as expanded securities powers. . . It is the political power of these various groups rather than economic rationale that protects them. ....

Thus, the newly-weakened Japanese commercial banks may be unable to prevent ownership fragmentation unless they get new authority, which the American-created interest groups so far impede. If full fragmentation does occur in Japan, politics-this time, interest group politics-will play some role.

While securities firms want to preserve one part of the current systemsegmentation - managers want to preserve another part - cross-holdings, which protect them from takeovers and usually give them large friendly shareholders. If banks cannot continue their role in the keiretsu, managers want a substitute, not the unknown. Their representatives argue that "any hard-landing approach which restricts . . . cross-holding . . . risk[s] . . demolishing the base of [the] Japanese management systems, and will never be accepted by a national consensus and must be avoided by all means." 155

Political history affects why the American and Japanese banking systems look so different. A half-century ago, both Japan and America faced bank

151. See ZIELINSKI \& HOLLOWAY, supra note 80 , at 70 (stating that post-retirement-at 55-jobs keep some Ministry of Finance officials attuned to interests of banks, others to that of brokers); Elliot Gewirtz \& Clark Taber, Fundamental Issues in Japanese Financial System Reform, 7 REV. BANKING \& FIN. SERVICES 135, 141 (1991); Litt, Macey, Miller \& Rubin, supra note 146, at 404-22 (describing conflict between Japanese bankers and brokers concerning banks' underwriting of commercial paper); James Sterngold, A Japanese-Style "Old Boy" Network, N.Y. TIMES, June 7, 1991, at D1 (discussing efforts of Ministry of Finance to resolve conflict between bankers and brokers concerning decision to allow banks into securities business).

152. [Japanese] Securities and Exchange Council, How Basic System Regarding Capital Market Ought to be Reformed 17-18 (June 19, 1991) (unpublished report, on file with author).

153. [Japanese] Financial System Research Council, On a New Japanese Finance System (June 25, 1991) (unpublished report, on file with author).

154. ROSENBLUTH, supra note 79, at 94-95.

155. Foundation for Advanced Information and Research, Japan, A Perspective on Japanese Merger \& Acquisition from International Viewpoint 23 (Sept. 1990) (unpublished report, on file with author) (emphasis added); see also RYUTARo KOMIYA, THE JAPANESE ECONOMY: TRADE, INDUSTRY, AND GOVERNMENT 255-56 (1990); Gerlach, supra note 33, at 117 (describing Japanese executives as opposed to stopping cross-holding). Changes in Japan's pension funds may create a huge emerging pool of capital. ROSENBLUTH, supra note 79, at 75. Whether intermediaries or managers control these funds may determine the future of Japanese corporate governance. 
crises. Politics led each nation to react differently. Japan then had thousands of small banks. Japan also lacked a populist, antibank ethos. ${ }^{156}$ During the 1927 economic crisis, many small banks were badly run and failed, while the large ones were fairly well-run and stable. Depositors ran off to the government's savings system, the large banks survived, and the government encouraged mergers among the small banks, ${ }^{157}$ concentrating banking. Today, Japan no longer has thousands of small banks.

In 1933, America had a similar banking crisis and a different political result. The United States, like Japan, had thousands of small banks. When many of them faced collapse in 1933, they pressed Congress for federal deposit insurance at the same time Glass-Steagall separation was on the agenda. The interest-group impetus for extensive deposit insurance has been the political power of small country banks. They got it enacted, ${ }^{158}$ extended, and beat back attempts to get it under control. ${ }^{159}$ Without it, American banking would have become more concentrated as many deposits would have run off from small, weak country banks to larger, often stronger, money-center banks. ${ }^{160}$ Recognizing this, the large banks supported Glass-Steagall separation because in 1933 they were not making money in the securities business and they hoped this support would deter deposit insurance. ${ }^{161}$ The large banks miscalculated, however, and Congress, after passing the GlassSteagall Act, also passed deposit insurance, which to this day continues to prop

156. T.A. BISSON, ZaibATSU DisSOlution IN JAPAN 29 (1954) (quoting U.S. DEPARTMENT OF STATE, PUb. No. 2628, REPORT OF THE Mission ON JAPANESE COMBINES, FAR EASTERN SERIES 21 (1946)) ("Since the [Meiji] restoration .... [t]here has never been any movement in Japan strong enough to produce a Sherman Act, ... a Money Trust Investigation, a Federal Trade Commission, or a Securities and Exchange Commission such as developed in the United States . . . .").

157. Frances Rosenbluth, Bank Consolidation in Prewar Japan: The Market for Regulation under a Non-Sovereign Diet 10-14, 17-25 (Mar. 1991) (unpublished manuscript, on file with author).

158. Carter H. Golembe, The Deposit Insurance Legislation of 1933: An Examination of its Antecedents and its Purposes, 76 POL. SCI. Q. 181 (1960); see also Gerald P. O'Driscoll, Jr., Deposit Insurance in Theory and Practice, in THE FINANCIAL SERVICES REVOLUTION: POLICY DIRECTIONS FOR THE FUTURE 165 (Catherine England \& Thomas Huertas eds., 1988) and sources cited therein; $c f$. Donald C. Langevoort, Statutory Obsolescence and the Judicial Process: The Revisionist Role of the Courts in Federal Banking Regulation, 85 MiCH. L. REV. 672, 695-97 (1987).

159. Kenneth H. Bacon, White House Bill on Bank Law Reform Faces Hurdles as It Goes to House Panel, Wall ST. J., May 14, 1991, at A24 (reporting Independent Bankers Association's attempts to head off Treasury effort to limit deposit insurance coverage). Some deposit insurance for the poor and middleclass is socially desirable and could explain a down-sized system, but cannot explain the extensive system America has. See generally Robert C. Clark, The Soundness of Financial Intermediaries, 86 YALE L.J. 1 (1976).

160. Some strength of large money-center banks came from being "too big to fail," meaning that the government-in modern times the Federal Deposit Insurance Corporation or the Federal Reserve-would prevent the failure of any really big bank.

161. Langevoort, supra note 158, at 690-91; cf. Jonathan R. Macey, Special Interest Groups Legislation and the Judicial Function: The Dilemma of Glass-Steagall, 33 EMORY L.J. 1, 2 (1984). 
up thousands of small banks. ${ }^{162}$ Politics subsidized the small banks, and the United States still has thousands of them.

A populist, antibank ethos is historically absent in Japan. ${ }^{163}$ Like Germany, this was partly because until the postwar era Japan was not a democratic country where such opinions could much influence government decisions. But consider the current turmoil in the Japanese economy. One problem facing Japan is that many firms are in mature product markets and have substantial free cash flow, which the firms can retain, freeing themselves from the bankers, who first gained influence because they were the necessary providers of now unneeded cash. Two tests of the current structure now loom: First, will stockholding banks keep their stock and will they induce portfolio firms to use the cash well? Second, if the banks succeed but make managers and workers unhappy, say, by ending lifetime employment, a major test of the political theory would arise. In America the disadvantaged groups would try to shift decisionmaking from the market to the political arena, appealing to the legislature to re-do the economic result. While in Japan that appeal might fail, politics there is not so different that we should expect disgruntled silence from those affected. We shall see.

$$
* * * * *
$$

I make no claim to a satisfactory understanding of the political history of Germany and Japan and its effects on financial intermediaries and corporate structures. Although others will have to deepen and correct the history I've presented here, even this cursory review shows that political forces have shaped the German and Japanese corporate structures-forces that differ both in kind and sometimes in strength from those that shaped American financial intermediaries and American corporate governance. The point is not that the foreign systems are less politically determined than America's. German codetermination in the face of revolution is hardly apolitical. The Japanese decision after 1927 to concentrate their banking system was not apolitical. The point is that different historical politics led to different financial institutional structures, and different institutions led to different corporate governance structures. Today, populism in Germany weakens the power of German bankers in the boardroom through formal codetermination and the informal effects of popular resentment; interest group infighting in Japan and the

162. TsuTSUI, supra note 143 , at 3-4, 11; Juro Teranishi, Financial System and the Industrialization of Japan: 1900-1970, BANCA NAZIONALE DEL LAvoro Q. REv., Sept. 1990, at 309, 329-30; Juro Teranishi, Availability of Safe Assets and the Process of Bank Concentration in Japan, 25 ECON. DEV. \& Cultural ChaNGe, Apr. 1977, at 447, 448-49, 462, 465, 469. Moreover, even earlier, after a bond failure in the nineteenth century, the Ministry of Finance sought to make banking somewhat more concentrated. Gary Saxonhouse, Mechanisms for Technology Transfer in Japanese Economic History, 12 MANAGERIAL \& DECISION ECON. 83, 85 (1991) (citing 1 NIHON GINKO HYAKUNEN SHI (A HUNDRED YEAR HISTORY OF THE BANK OF JAPAN (1982)).

163. BISSON, supra note 156 , at 29. 
American-imposed legacy of partial fragmentation limit the power of Japanese bankers in industry.

\section{SHARED AUTHORITY: WEAKNESSES AND STRENGTHS}

My primary goal in this Article is to show that there are differences in corporate structure, that the German and Japanese structures would be illegal in the United States, and that existing corporate theories, which focus on economic factors and do not consider political forces, cannot adequately explain the differences. My goal in this Part is first to find the ways in which German and Japanese corporate governance structures resemble each other, while departing from the American structure, and then to develop hypotheses for future investigation about the link between structure and performance.

I realize that readers of a competitiveness symposium would prefer that I offer a corporate governance silver bullet to cure whatever economic ills afflict American industry. My goal here is more modest. It is not to show that the foreign structures are superior, and hence should be adopted here. Indeed, my essential claim is not that the foreign structures are superior, but that they are different. Moreover, prescriptions for America can be best discerned by examining American corporate governance. Any governance feature that would improve American corporate governance would make American firms more competitive. There is no reason to confine a normative inquiry to features of the foreign firms.

Were this Article not part of a competitiveness symposium, I would not include a prominent normative section because the current data is far too thin to make concrete recommendations based on the foreign systems. Anyone advocating that some feature in a foreign system be adopted here would have to respond to criticism focusing on the feature's cost, and we lack the data necessary to evaluate the relative magnitudes of benefits and costs.

I doubt that corporate governance-even if we knew how to achieve the perfect system-is central to economic performance and competitiveness. Macroeconomic policies, competition, industry structure, and the education and motivation of managers and employees each surely affect competitiveness and productivity more than does corporate governance. Good performance abroad will be difficult to trace to corporate governance; and conversely, poor performance abroad does not mean that foreign governance is worse. ${ }^{164}$

164. Thus one might point to America's competitive superiority after World War II, as is pointed out in Roberta Romano, A Cautionary Note on Drawing Lessons from Comparative Corporate Law, 102 YALE L.J. 2021 (1993), when the U.S. had, more or less, the same corporate governance system then as it does now. So, one might argue, let's ignore corporate governance as a possible American weakness. There were many reasons for America's relative competitive superiority over Germany and Japan in 1945. It is logically possible that America's corporate governance was bad then and bad now, but because governance is a tertiary economic feature, it didn't drag down the American economy. Similarly, as I argue below, it is possible that American corporate governance is, overall, superior to foreign corporate governance now, and 
Moreover, the foreign systems begin with several obvious defects. Japanese cross-ownership and German bank proxy control are afflicted with deep conflicts of interest, which could deteriorate into mutual managerial selfprotection in Japan and opportunism in Germany. Neither foreign system is likely to yield entrepreneurial leadership; committees are not entrepreneurs, and the foreign institutional allocation of capital seems to do poorly in financing new entrepreneurial firms. Both foreign systems are associated with heavy state direction, which has tended not to work well in the United States, and may yet prove to work poorly abroad. My goal therefore is not to show that the foreign systems have an overall superiority, but to find theoretical benefits that might offset the foreign structures' obvious costs.

Any normative inquiry also suffers from the fact that Japanese, and perhaps German, firms may maximize size, not profits. ${ }^{165}$ Because one-third of the cross-holdings in Japan are held, not by financial institutions, but by industrial firms, which are as interested in their own sales as in profits from owning stock, and because employees' representatives make up half of the German board and are as interested in jobs as in profits, belt-tightening and down-sizing would not be easy. If so, the foreign systems may work well when economic determinants impel expansion, but not when expansion is no longer warranted. The U.S. system may be more adaptable and, when the pluses and minuses are added up, superior. For example, American managers own more stock and America's efforts at pay-for-performance (despite how badly it is implemented here) may motivate management better than German or Japanese approaches. The primary theoretical advantage in the foreign structures-institutions with very large blocks of stock whose agents interact regularly with management-may disappear in the future if American intermediaries continue to concentrate their holdings and become more active.

One last problem afflicts the normative inquiry. How can an increase in banker power reduce managerial agency costs without increasing banker agency costs? Empowering financial institutions may improve the performance of owners' agents in the corporation, but, by expanding the duties of the owners' agents in the financial institution, create new problems. Measuring whether the gains exceed the losses will be hard. But, perhaps a reduction in agency costs is not the central problem that institutional ownership addresses. Indeed, more than corporate governance-the agency problems of managers arising from fragmented stock ownership-is affected by the structure of large firm ownership. The problems that institutional stockholding in a flatter

was even then. But that should not stop us from looking at foreign ownership structure to see if it offers any lessons for America. I see no reason why we should not try to take the incremental gains and leave behind the losses, if we can.

165. Alan S. Blinder, Profit Maximization and International Competition, in 5 FIN. \& INT'L ECON.: AMEX BANK REv. PRIzE EsSAYS 37 (Richard O'Brien ed., 1991). 
hierarchy might mitigate fall into three categories: problems in management; problems in financial markets; and problems in organizing large scale industry.

\section{A. Problems with Management}

Contrary to conventional wisdom, bank ownership abroad did not shift control from managers to banks, but led to power-sharing. Day-to-day bankershareholders do not run the firm; they intervene in crises and may hold managers accountable in the interim. Managers presumably try to avoid those crises and the threats these blocks bring to their own autonomy. Second, several intermediaries usually hold big blocks of stock in large firms-no one intermediary dominates. Third, the intermediaries are highly leveraged institutions that cannot afford to make a serious error. Fourth, the stockholder is personified, changing the way managers view owners. Fifth, shared authority allows more people from different organizations into decisions at the top, reducing inbred decisionmaking.

\section{Increasing Accountability}

Although reducing agency costs may not be the key advantage, if there is one, to the foreign systems, increased accountability should not be overlooked. American managers have historically been less accountable to shareholders than their foreign counterparts, ${ }^{166}$ despite big gaps in foreign accountability. While the trend may be toward less accountability abroad and more accountability here, differences still exist.

Thus, a first hypothesis is that the German and Japanese corporate structure motivates the board to be more conscientious. The German and Japanese CEO must meet with the representatives of big stockholders who do not always owe their positions to the CEO, but owe them to their home institutions, and who do not depend financially or socially on the CEO, a dependence that afflicts American directors. ${ }^{167}$ In Germany, managers, who handle day-to-day matters, interact with institutional stockholders when reporting to the supervisory board of directors in regular, formal meetings. German bank directors, unlike some American directors, are not appointed to the board because they have a reputation for passivity, but frequently because their institutions vote big blocks of stock. And in Japan, managers dominate the internal board that handles day-to-day matters but interact with big stockholders in regular, informal Presidents' Council meetings. Key members

166. Cf. Bernard S. Black, The Value of Institutional Investor Monitoring: The Empirical Evidence, 39 UCLA L. REV. 895, 898-916 (1992) (discussing gaps in American accountability).

167. JAY LORSCH \& ElIzABETH MACIVER, PAWNS OR POTENTATES: THE REALITY OF AMERICA's CORPORATE BOARDS (1989); Victor Brudney, The Independent Director-Heavenly City or Potemkin Village?, 95 HARV. L. REV. 597, 598 (1982). 
of the supervisory board and the informal Presidents' Council owe their allegiance to their own institutions and thus have reason not to follow the CEO blindly. Moreover, because the CEO cannot join the German supervisory board and faces several big stockholders in the Japanese Presidents' Council, the CEO is not able to co-opt the external monitors completely. Thus, in both foreign nations, managers dominate an internal board, but not the external supervisory board or the Presidents' Council. In America, in contrast, corporate governance involves only a single board, which the CEO has historically dominated.

Although neither foreign meeting structure facilitates a detailed review of senior managers-German supervisory boards meet a few times per year, usually without a searching agenda, and Japanese monthly Presidents' Council meetings involve so many firms that no one firm will usually be the focus of attention-these meeting structures are fit for crisis management and bigpicture, ongoing review. Hence, even though foreign CEO's are not subject to day-to-day direction from institutional investors, as is sometimes thought, they are weakly accountable to institutions whose continuing involvement makes them knowledgeable about the CEO's business. Managers get their chance, and the intermediaries intervene primarily when managers fail. Certainly data on executive turnover shows that German and Japanese ownership does not deter removal of executives when performance slackens; ${ }^{168}$ involuntary resignations increase when the Japanese economy weakens. ${ }^{169}$ This belies assertions that the big stockholders insulate managers from removal. The question remains whether these removals are fast enough or occur in the right circumstances, and whether the removals actually improve corporate performance. Large stockholders' ongoing involvement means they do not need time to move up from the bottom of a learning curve and can intervene quickly when crises hit. Finally, the potential for institutional interruption in crisis should improve firm performance as managers try to avoid those crises. ${ }^{170}$

\section{Monitoring by Multiple Intermediaries}

German and Japanese firms usually have several intermediaries holding big blocks' of stock. Multiple intermediaries can (1) deter opportunism by monitoring one another; (2) impel action in a way that a single blockholder might not; and (3) facilitate power sharing, not domination. Rarely does a

168. See Kaplan \& Minton, supra note 36; Steven N. Kaplan, Top Executives, Turnover and Firm Performance in Germany (Feb. 1993) (unpublished manuscript, on file with author).

169. See supra notes $36-37$.

170. These elements of shared authority comport with agency theory, which suggests that organizations can separate some management and control functions internally by (1) using a hierarchy in which a subordinate initiates and a superior ratifies and monitors; (2) using a board that seriously reviews top managers; and (3) mutual monitoring across decisionmakers. Jensen \& Smith, supra note 8, at 101. 
single dominant bank own a control block. Thus, the foreign structures do not replace an American-style commanding $\mathrm{CEO}$ with a foreign-style commanding bank officer.

\section{a. Multiple Blocks Checking Each Other}

A single bank in control of a firm could charge an above-market interest rate, compel the firm to do fee-generating deals, divert value from the firm to itself, or pursue its own empire-building agenda. ${ }^{171}$ First, because each system tends to have multiple intermediaries-Deutsche Bank's dominating $28 \%$ block of Daimler-Benz is exceptional-the risk of bank opportunism is diminished (although hardly eliminated). German firms usually borrow from several banks and German loan rates are said not to include a premium for banker control; ${ }^{172}$ Japanese firms occasionally end their relationship with the main bank and seek another. ${ }^{173}$ To form a coalition, the bank must appeal to the others. That appeal may be opportunistic, but the multiple parties involved give managers the chance to break an opportunistic coalition. Since the managers control some stock in the financial institution, they have a base upon which to build a counter-coalition to oppose the opportunist. A true managerial crisis inside the firm, however, should unite the stockholders-all want to end the crisis-but the opportunist may have trouble acting alone. ${ }^{174}$

\section{b. Multiple Blocks Impelling Action}

Why don't American financial intermediaries-some of which can own some stock-go to the law's limits in stockholding? Isolated blocks, even big ones with $5 \%$ of the portfolio firm, are precarious because management may isolate, outmaneuver, and destroy them. ${ }^{175}$ In America, a single 5\% block does emerge here and there, but managers still have the upper hand in times of conflict. Even a half-dozen institutions with $5 \%$ blocks would have to coordinate their activities, which U.S. securities regulation historically deterred.

171. See Stuart Rosenstein \& David Rush, The Stock Performance of Corporations That Are Partially Owned by Other Corporations, 13 J. FIN. RES. 39 (1990).

172. John Cable, Capital Market Information and Industrial Performance: The Role of West German Banks, 95 ECON. J. 118, 118-19 (1985); see also Eckstein, supra note 126, at 478.

173. Ramseyer, supra note 145; Toshiaki Tachibanaki \& Atsuhiro Taki, Shareholding and Lending Activity of Financial Institutions in Japan, 9 BANK JAPAN MONETARY \& ECON. STUD. 23, 24, 31 (1991) (reporting that one in four firms switched main banks in a four-year period).

174. Even this is not a complete explanation. Institutions might form coalitions. Banker $A$ may agree with Banker $B$ that $A$ will exploit company $X$ while $B$ exploits company $Y$. Nonetheless, such coalitions, like cartels, are often difficult to construct and to maintain. Moreover, bankers should fear that visible opportunism will provoke political retaliation, particularly in Germany. Politics constrains.

175. Large stock positions in big American firms are rare. One example was H. Ross Perot's $6 \%$ stake in GM. Perot gained access to the GM Boardroom, but when the GM managers discovered that he was a feisty critic, they threw him out. Perot was not able to form an alliance with other large stockholders because there were no others. See Table II. 
Thus, some "unleashed" American institutions should rationally refuse to hold the maximum permitted by American law because they know that in times of crisis they will need a critical mass of other large blockholders, a critical mass they lack.

The ownership structures in both Germany and Japan have weaknesses in impelling action. The German banks' big voting blocks usually come from brokerage stock, for which the German banks are not likely to make heroic efforts at monitoring. ${ }^{176}$ Each Japanese bank owns no more than $5 \%$ of an industrial firm's stock, a position that is frequently too weak to wrest control from managers in the United States. A German bank's typical directly-owned, nonbrokerage position, while larger, is usually too small standing alone to give the bank control; with brokerage stock or alliances with other stockholders, the bank can obtain control.

Multiple blocks may induce intermediaries to act in a way that a single isolated blockholder might not. The multiple blocks may solve the weakness problem, without creating a dominating block that recentralizes authority in a dominating intermediary. The roles of German brokerage stock and of multiple Japanese 5\% blocks may not be to share expense with the active intermediary, but to give voting power. Directly-owned stock gives the institutional owner a financial incentive to act; ancillary, backup stock bulks up voting power to provide the means. ${ }^{177}$

\section{c. Multiple Blocks and Power Sharing}

If foreign intermediaries are large Berle-Means firms (actually many are not), ${ }^{178}$ they could have too many scattered shareholders to give their agents the proper incentives. Why should reducing managerial agency costs at the firm not just displace the problems up one level into financial intermediaries, making bankers the source of a new agency problem?

This question may make the normative inquiry a dead end. But power sharing differs, at least in form, from completely shifting authority from managers to bankers. ${ }^{179}$

176. High registration fees drive individuals' stock into banks, whose custodial fees are not tied to performance. See BAUMS, supra note 16, at 25-27. The banks could be paid via conflicts of interest that allow them to divert resources from the firms to themselves, presumably via favorable loan terms or high fees for deals, but the current evidence says this does not in fact happen. Cable, supra note 172, at 119-24.

177. If political pressure on German banks leads them to reduce their amount of directly-held stock, see supra text accompanying notes 130-133, while retaining their brokerage stock, they may face reduced incentives to act responsibly.

178. The Japanese banks are primarily cross-owned by other Japanese financial institutions and industrial companies; in Germany, one of the three big banks is also partly cross-owned by a large insurance company and industrial firm.

179. Shared authority affects monitoring, a fact that is this Subsection's focus. It can also affect the quality of decisions, the focus below. See infra text accompanying notes 185-188. 
This shared authority lies between market and hierarchy, linking finance and industry in a complex way. Control is not the right word to describe these relationships. Interlock, or Escher-like overlap, might be more apt. ${ }^{180}$ An Escher-like hand reaches out from the bank to control the firm, but then an Escher-like hand reaches back from the firm to control the bank.

To see this, trace the historical authority of the Japanese banks. In their heyday, through their control over credit, they could control firms, review their budgets, and monitor their managers. They owned stock in the monitored firms. The assets of the monitored firms included the stock of the monitoring banks. The banks could influence firms through their stockholdings, and the firms could influence the banks through their own stockholdings. The banks thus were not (and are not now) precisely Berle-Means firms.

Escher-like overlap also describes corporate governance in Germany, although less clearly. Bankers have seats on industrial firms' supervisory boards and managers from important industrial firms are members of the banks' boards and on the banks' informal national advisory boards. ${ }^{181}$ Moreover, managers direct employees, some of whom sit on the supervisory board and direct managers. Corporate governance structures in both nations resemble less a hierarchical pyramid-the American picture-than an Escherlike staircase-while always walking downstairs, we wind up on top of the staircase from which we started.

This interlocking, shared power model comports with the Japanese structure in two ways. No single bank dominates a firm's stock ownership; only a group can dominate. Moreover, groups of firms cross-own some influential blocks of stock in the banks. This Escher-like interlock model comports with the German structure in one way-only a coalition can completely dominate the firm. Two of the three large German banks are, however, themselves Berle-Means firms with scattered shareholders, a consideration we analyze next.

\section{Monitoring the Banks}

Ignore cross-ownership of the banks for now-as we must for two of the three large German banks and as we can for the Japanese banks-by considering institutional ownership's effectiveness in another setting. How can the banks monitor when they themselves are presumably afflicted with agency problems? As we have said, this may make this part of the normative inquiry a dead end. But consider the banks as embedded in a simple tri-level

180. M.C. Escher was a Dutch graphics artist with whose work most readers will be familiar. Escher's drawings show, for example, realistic renditions of staircases that descend to the top of their own ascent and walls that abut ceiling and floor at the same joining point.

181. Kibler, supra note 133, at 109. The new ownership interlock between Dresdner and Allianz strengthens the overlap. 
hierarchical monitoring model with industry at the bottom, financial institutions in the middle, and government regulators at the top. Although the intermediaries monitor industry, they are themselves free from day-to-day control. So, who monitors the intermediaries? No one, day-to-day. But the government monitors leveraged intermediaries and, when it gets a signal of financial weakness from the banks, it begins inquiries that weaken bank managers' autonomy. ${ }^{182}$

In this model then, banks' weakness-high leverage with thin equity-becomes a strength, if properly regulated. Leveraging and regulation cause the senior bank managers to get good returns and avoid financial disasters at portfolio firms in order to avoid a thinning of the bank's own equity, which would trigger regulatory intervention. Bank ownership increases the accountability of managers, but without an equal and offsetting increase in agency problems in the stock-owning bank because the leveraged bank has financial and regulatory reasons to avoid a severe decline in its stock portfolio. ${ }^{183}$

\section{Personifying Shareholders}

American managers owe fiduciary duties to an abstraction, a faceless stock market. In Germany and Japan, on the other hand, this abstraction is personified through regular interactions with bank directors (on the supervisory board) or the bank presidents (at the council meeting). The derelict foreign CEO risks not just betraying abstract duties to an anonymous market, but also betraying people from a stockholding institution. Loyalty to real people may motivate better than legally mandated loyalty to an abstraction.

German and Japanese managers, due to constant interaction with people from stockholding institutions, should feel greater peer pressure, guilt about shirking, more camaraderie, and more empathy among coworkers, all of which could improve performance. ${ }^{184}$ CEO's may be more willing to hurt an anonymous stockholder, whose needs are not vivid and present, than they can hurt a cohort. Isolated American managers, on the other hand, are likely to see

182. Cf. Douglas W. Diamond, Financial Intermediation and Delegated Monitoring, 51 REV. ECON. STUD. 393 (1984); Michael C. Jensen, Agency Costs of Free Cash Flow, Corporate Finance, and Takeovers, 76 AM. ECON. REV. (PAPERS \& PROCEEDINGS) 323 (1986).

183. This may seem like a problem with institutions and hence could belong to the next Section, which discusses problems with financial markets. But it is best thought of as a problem of management accountability that bank ownership theoretically can help, without creating equal and offsetting problems in the upstairs institution.

184. See Eugene Kandel \& Edward P. Lazear, Peer Pressure and Partnerships, 100 J. PoL. ECON. 801 (1992); cf. Strong v. Repide, 213 U.S. 419 (1909) (though insider stockholder can mislead the market, a face-to-face seller cannot). The risk of course is that personification leads to a failure to hold managers accountable for their mistakes.

Sociologists found few Americans soldiers fought "for freedom," "for the American way," or "against aggression"; motivation came not from these abstract ideals, but from loyalty to peers in the platoon and fear of embarrassment in front of them. JOHN KEEGAN, THE FACE OF BATTLE 50-53, 72-73 (1976). 
shareholders, not as friendly institutions expecting a profit, but as anonymous traders with little loyalty to the firm. American CEO's may see even the newly-emergent institutional investors having stable but small blocks as too distant to merit loyalty and respect-a loyalty and respect that could arise from regular interaction in a governance or quasi-governance setting, such as in the Presidents' Council or in interaction with the supervisory board.

\section{Improving Decisions}

Shared authority may increase managerial accountability, but that is not its only potential benefit. Organizational theory suggests another reason why this partial vertical integration may be useful. Complexity reduces an individual's ability both to comprehend all that is necessary and to avoid bias from outmoded experience. In a modern, complex economic system, information is too dispersed; no individual or staff can have all of the information needed for decisionmaking. Networks can do better, the theory goes, than any one individual or hierarchy. Moreover, since a decisionmaker's biases are often invisible to the decisionmaker, a single individual will do worse than a network of decisionmaking, which reduces error, ${ }^{185}$ similar to the way a good law firm with many high quality people in overlapping fields can cooperate, converse, and get the job done better than a lawyer of equal quality working alone. Unlike the American conglomerate, foreign structures do not replace the CEO with a new centralized decisionmaking authority. Cross-holding allows more interested parties to participate in the decisionmaking at the top. In some settings, wider participation may help; neither the individual CEO nor the headquarters at the top of firms in technologically complex and fast moving industries may be able to assimilate all the important information needed for critical decisions.

The problems of misinformation and bias can be generalized. Market transactions have costs; command and hierarchy replace market costs with organizational costs. Relative cost determines organizational structure; firms arise when a hierarchical structure provides a more efficient means of organizing than transactions in the marketplace. ${ }^{186}$ The foreign systems permit hybrids that could perform better than either pure type.

Changing underlying economic conditions could make hybrids more important than they once were. Increasing complexity of information is one. New theories of firm organization describe American-style command-andcontrol hierarchy as poorly adapted to today's continual information shifts and

185. See Raaj K. Sah, Fallibility in Human Organizations and Political Systems, 5 J. ECON. PERSP. 67, 69-71 (1991). (1937).

186. Williamson, supra note 4, at 82; R.H. Coase, The Nature of the Firm, 4 ECONOMICA (n.s.) 386 
technological changes. ${ }^{187}$ Although the pyramid of decisionmaking worked well when mass production of slowly changing products was typical, the difficulties of producing today's complex products in rapidly changing markets may make a flatter authority structure at the top better.

Some cross-owned firms in Japanese keiretsu are vertically related and would be part of a single large vertical firm in the United States. By involving more individuals in decisionmaking at the top, the flatter authority structure present in German and Japanese firms may serve better to motivate managers, particularly those who would be farther from the top in the American vertically integrated firm. Indeed, "[r]esearch suggests that hierarchical design dampens employee motivation because individuals are ... more committed when they have participated in a decision, and much less enthusiastic when ... ordered by superiors to undertake a particular task." 188

The incentives, sense of responsibility, status, and hence motivation of senior managers at semi-independent keiretsu firms should differ from those of managers who run American-style divisions or wholly-owned subsidiaries. Keiretsu CEO's should be able to call on stockholder-financiers directly, while division managers and subsidiary heads must first speak with their firm bosses.

Cross-ownership may also help motivate lower-level employees by supporting the implicit lifetime employment contract that is only now weakening in the core keiretsu firms. Although stockholders without any other relationship to a firm will sometimes renege on an implicit agreement, stockholder-suppliers might honor the agreement because the gains they reap as reneging stockholders would be reduced by the losses they incur as affected suppliers. Suppliers may fear demoralization of their own employees, who would have to deal with some of the victims, employees of the customer-firm who no longer benefit from lifetime employment. Also, as stockholders involved with multiple relationships-suppliers and stockholders, creditors and stockholders-they may avoid high variance strategies that often benefit stockholders but hurt creditors, suppliers, customers, and employees. To protect themselves as customers, suppliers, or creditors, cross-holding stockholders may protect employees even if, in so doing, they decline to take risks that would maximize the value of their stock.

187. Peter F. Drucker, The Coming of the New Organization, HARv. BuS. REv., Jan.-Feb. 1988, at 45, 53.

188. Walter W. Powell, Neither Market Nor Hierarchy: Network Forms of Organization, 12 RES. ORGANIZATIONAL BEHAV. 295, 319 (1990). 


\section{B. Problems with Financial Markets: Institutions as the Problem}

\section{Enhancing the Information Flow}

The ownership structure in Germany and Japan should improve the flow of information from inside the firm to large shareholders, thus helping to deter the short term propensities often seen in the stock market. ${ }^{189}$ To do this in the United States, managers would have to reveal complex, proprietary information to the stock market, and derivatively to competitors. ${ }^{190}$ Moreover, evaluations of technical data from inside the firm may require regular, private interaction between large stockholders and managers, which the foreign structures provide but the American structure does not. ${ }^{191}$

\section{Improving Loan Markets}

Bankers may buy stock in their debtors to create an additional mechanism for protecting their loans or providing a secondary information channel to support their loans. ${ }^{192}$ Bankers may also buy stock to limit their own opportunism-a threat not to rollover short-term loans unless the debtor grants concessions is less credible when carrying out the threat would reduce the value of the stock the banks hold. Finally, because bankers tend to be concerned with loan repayment and not with maximizing firm value, they and their debtors may both prefer that they buy stock to mitigate their conservatism. ${ }^{193}$

Lastly, when creditors also have large stock positions, workouts and recapitalizations to avoid a complicated and costly bankruptcy proceeding are probably easier.

189. I first argued this possibility in Roe, Political Theory, supra note 1, at 55-56.

190. Bruce Atwater, the savvy CEO of General Mills, admits that he tries to learn of his competitors' activities from analysts. Bruce Atwater, The Governance System Is Sound, DIRECTORS \& BOARDS, Spring 1991, at 17, 19. Presumably CEO's severely limit the amount of proprietary information they release to analysts.

191. Takeo Hoshi et al., Corporate Structure, Liquidity, and Investment: Evidence from Japanese Panel Data, in ASYMMETRIC INFORMATION, CORPORATE FINANCE AND INVESTMENT 105 (R. Glenn Hubbard ed., 1990); Stephen D. Prowse, Institutional Investment Patterns and Corporate Financial Behavior in the United States and Japan, 27 J. FIN. ECON. 43 (1990).

192. Obviously, the influence from stock may yield the mutual self-protection that weakens the German and Japanese systems: The stockholding bank may induce the portfolio firm to borrow on terms unfavorable to it.

193. Insider trading helps to explain why banks buy stock, or at least what happens once they own it, particularly in Germany, where, due to a lack of insider trading laws, bank officers can and do trade on inside information from firms. While insider trading surely explains some stockholding, it cannot explain all of it, because of the Japanese banks' stability in ownership (insiders have to trade to make profits), the timing of their acquisitions (they all bought in more or less at the same time, to stabilize firms in the face of American strength and takeover possibilities), and the uniformity of $18-20 \%$ bank ownership in the top companies (every firm cannot be a better than average deal). 


\section{Problems in Large-Scale Industry: Organization}

Credible commitment analysis helps to explain the role of cross-ownership in Japan, where one-third of the cross-ownership of stock involves suppliers and their customers. ${ }^{194} \mathrm{~A}$ supplier wants protection before investing in new machinery to make a good that only a specific customer can use. What will stop the customer from extorting the supplier later on, after the supplier has the machine? Although a detailed contract between the supplier and the specific customer may protect the supplier, many of the ways that the supplier can be exploited are unforeseeable. Vague promises from a customer to act in good faith are often not enough. Multiple cross-holdings of stock, however, may mitigate opportunism. If the customer tries to mulct the supplier after the supplier has committed itself, a coalition of stockholders could intervene to stop the opportunism. ${ }^{195}$

A bank's investment in a long-term loan ${ }^{196}$ resembles a supplier's investment in complex machinery for a specific customer. The borrower may renege on the loan by increasing the level of risk or, as noted above, the lender may renege by refusing to rollover the loan at a critical juncture. In the United States, detailed loan agreements mitigate these problems. Perhaps in Japan cross-ownership limits borrower-lender opportunism and thereby facilitates trade in capital. ${ }^{197}$

In both supplier-customer relationships and lender-borrower relationships, the relational commitment is made credible by the plausibility that a coalition will form to control the opportunist. Cross-ownership among related customers and suppliers-whether of machinery or of capital-resembles a hostage exchange in which each side gives the other a hostage whose loss will be costly to the offering party but whose value to the side holding the hostage is little. By acting opportunistically, a supplier risks not only the direct intervention of the others but, because the supplier is bound in a web of crossholdings and relational investments, the supplier will devalue these other important relationships. If a supplier acts opportunistically, the customer can sell the supplier's stock in the market and encourage the other firms in the cross-holding web to sell their stock in the opportunist. Such sales would hurt managers at the opportunistic supplier, who would be "naked" and at the risk

194. Yusaku Futatsugi, What Share Cross-Holdings Mean for Corporate Management, ECON. EYE, Spring 1990 , at 17,18 . Industrial ownership of stock is also significant in Germany.

195. See Gilson \& Roe, supra note 100 .

196. Some of these loans may, in form, be short-term loans, particularly in Japan. When these loans are rolled over regularly, they effectively become long-term loans.

197. In fact, this scenario is quite complicated. If fiduciary duties are weaker and more difficult to enforce in Japan than in America, the Japanese system may require cross-ownership to function. Thus, the Japanese may bear the costs of cross-ownership-whatever they may be-because they lack other mechanisms for enforcing contracts and fiduciary duties. 
of takeover. The selling customer recovers the market price of the stock; the opportunist is, however, made to operate in a riskier environment. ${ }^{198}$

Relational contracting problems may overlap with corporate governance problems. Multiple relationships, such as suppliers and customers owning each other's stock and trading goods, and lenders and borrowers owning each other's stock and trading loans, double up (1) the sources of information; (2) the incentives to participate in the governance of the firm, since a failing investment is also a failing customer; and (3) the means of intervention, allowing for both exit and voice.

$$
* * * * *
$$

The point of the inquiry in this Part is not to prove foreign superiority, but (1) to suggest where to look for their strengths; and (2) to see that there is a prima facie case that their debilities-perhaps they will be slow-moving when down-sizing is warranted, are likely to overexpand when expansion is undesirable, or may fail to check errant managers due to mutual protection, not mutual checking-have some offsetting strengths that have so far enabled the foreign systems to survive.

\section{IMPLICATIONS FOR AMERICAN STRUCTURE}

Corporate structures in Germany and Japan have several common elements, including shared authority at the top, large financial intermediaries that hold concentrated blocks of stock, interaction of bankers and managers in structured settings, multiple intermediaries that split the vote, and personified shareholders. These common elements differ from American structure. And while the structures face severe risks of stagnation, they potentially have some hypothetical offsetting advantages in improving management, financial markets, and industrial organization.

But hypotheses are not proof. We lack a powerful theory, backed by clear data, showing how big blocks of stock might improve corporate performance. Thus, the point of comparing corporate structure in Germany and Japan on the one hand and the United States on the other is not to show that the foreign structure is superior. Instead, the central point of this Article is to show that the American governance structure is not inevitable, that alternatives are plausible, and that a flatter authority structure does not disable foreign firms. But that is not much reason to take the next step and recommend massive legal and economic change. A prima facie possibility is not a mandate for massive change. Even if some foreign firms are helped, it is doubtful that all are.

198. The sale can be seen not only as a "killing" of the hostage by destroying the mutually protective relationship, but also as a direct enforcement mechanism. The stockholders could oust the incumbent management directly by using their stock. In the sale alternative, they oust the opportunistic firm from the network, and leave the opportunistic managers to the perils of the market, which might then oust the managers. 
Although we do not yet want a legal regime that requires or even encourages American replication of the foreign corporate structures, we should want a legal regime that permits them. Right now, we do not have one that permits them.

\section{A. Germany and Japan as Blueprint?}

Yet rules that merely permit alternative structures might be pointless. For reasons that are not yet obvious, the international pattern is that a nation's large firms either all have concentrated institutional voice, or none do. The Japanese pattern in Table III does not reveal diversity, and nearly all American large firms have ownership structures like GM's in Table II. ${ }^{199}$ Economic deduction suggests that firms that would benefit from concentrated ownership by financial intermediaries would have it while firms that would not benefit from such ownership would have scattered ownership. ${ }^{200}$ But the international results - either all one way or all the other-suggest that a slight tilt in the power of intermediaries in either direction leads to concentrated voting or its absence. A nation might not be able to reap the gains from greater institutional voice where it works well without suffering losses where it detracts from performance- one more reason why this dimension for corporate governance reform may be a dead end.

Institutional influence here will not come primarily from banks, as it does abroad. As such, while we can make a case for tearing down the highest barriers to institutional involvement, I doubt that banking laws will be the center of such reform. Moreover, the political economy of American banking makes 'reform hard. There are ample reasons in favor of interstate branching, and remarkably few against it, but proposals to repeal the McFadden Act thus far have failed, largely because small-town, independent bankers form a powerful lobby. Second, because they have a highly leveraged structure, even unregulated banks will not become major direct equity players. ${ }^{201}$ To do so they would need at least modest direct holdings and larger holdings for others' benefit, like the holdings of the German universal banks. But, even if American intermediaries wanted such holdings-and the riskiness of having them makes such an inclination unlikely-such a new complex intermediary would require regulation that the American system cannot yet provide, and hence American regulators must prohibit it. Third, if reform promises to unleash bankers-an unlikely prospect-savvy managers, who were

199. See Table XIII.

200. See Demsetz \& Lehn, supra note 22 (describing sorting trend among American firms). If Demsetz and Lehn are right, sorting is plausible even if we loosen up institutional constraints.

201. Herwig Langohr \& Anthony M. Santomero, The Extent of Equity Investment by European Banks, 42 J. MONEY, CREDIT \& BANKING 243 (1985). Yet the leveraging, as we saw in Part IV, may propel successful monitoring. 
instrumental in defeating takeovers that challenged managerial autonomy, ${ }^{202}$ might weigh in to put bankers back on their leash. Fourth, fractional reserve banking is a declining industry-not the place to look to for future growth. ${ }^{203}$ Fifth, the path-dependent development of American banks makes them illequipped for the tasks of governance. German and Japanese banks "grew up" in the boardrooms (or Presidents' Councils) of their nations' industry; American bankers did not.

In deciding questions of bank size and solvency, we should not-and will not-give much weight to corporate governance issues. Bank solvency is too important. America's extensive deposit insurance (and the too-big-to-fail doctrine) makes banks and stock a volatile mixture. The biggest risk of unleashing American banks is less that they will disable industry than that they will disable themselves and pass these risks onto the public through deposit insurance. Reforming deposit insurance, however, has thus far proven to be nearly intractable-again, small banks have too much power. The Brady reforms were killed shortly after they were announced, ${ }^{204}$ and Congress has done little to limit deposit insurance. ${ }^{205}$ Congress' new effort to control the impulse to pay uninsured depositors at banks that are "too big to fail" is untestéd. Since we cannot unleash banks at the same time that we have unleashed deposit insurance, a plausible beginning might be to allow bank stock ownership, but only with very high capital requirements, which may make banks' participation in corporate governance merely aspirational for the foreseeable future.

The historical path of America's weak banking system may mean that close relations between America's largest banks and industrial firms are unlikely to develop. Evolution from today might take another path, however. The Federal Reserve could and should revoke its passivity promulgations;

202. Mark J. Roe, Takeover Politics, in THE Deal DeCade: What TaKeovers and Leveraged BuYOUTS MEAN FOR CORPORATE GOVERNANCE 321 (Margaret M. Blair ed., 1993).

203. Steven Lipin, Bank Industry Seen Shrinking in 1990s, Survey of Executives, Regulators Finds, WALL ST. J., Oct. 2, 1991, at A14. Some of the problems facing the foreign banks partly arise from the pressure on fractional reserve banking all over the world.

204. Ann Devroy \& Kathleen Day, Deposit Fee Draws Wave of Protest, WASH. POST, Jan. 26, 1989, at $\mathrm{Al}$.

205. The FDIC Improvement Act, which requires risk-based premiums by 1995 , limits payments above the explicit insurance ceiling, and encourages regulatory intervention prior to insolvency, may seem to reduce the impact of congressional failure to deal with the core problem of a high $(\$ 100,000)$ insured amount. FDIC Improvement Act of 1991, Pub. L. 102-242, 105 Stat. 2236 (1991) (codified in scattered sections of 12 U.S.C.). But we have yet to see how successful these reforms will be. Moreover, we do not yet have reason to believe that regulators will be able to act swiftly and effectively. America's procedural system could hinder even highly capable regulators. And America's political system allows affected banks to appeal to politicians to stop the regulators. See, e.g., Perspective-S\&L Scandal, CHI. TRIB., Dec. 9, 1988, at 26 (Speaker of the House Wright collected campaign contributions from the S\&L and real estate lobbies, and delayed closing down insolvent S\&L's). Furthermore, new efforts to control the impulse to pay uninsured depositors of banks "too big to fail" are untested. FDICIA $\S 141$ (a)(1)(C) (1991), 12 U.S.C. $\S 1823$ (c)(4)(E) (1988). Hence, I would rather see the system work effectively before we undertake serious deposit insurance risks, than to assume that shutdown reform will work and therefore the risks are manageable. 
Congress could and should remove the 5\% lid on holding company stock ownership and should instead tie stock ownership to holding company capital. Although few money-center banks are in a position to take advantage of these changes, many regional banks are in good shape ${ }^{206}$ and may take advantage of the new opportunities to become more involved with the governance of medium-sized companies, and some of these firms will grow to become America's largest companies.

Because American banks do not, and will not for the foreseeable future, directly hold big blocks of stock in America's largest firms, the focus of American reform will be pensions, mutual funds, insurers, and securities markets, not banks. Thus, the lessons from abroad-where bankers are primary-are at best general and superficial. ${ }^{207}$ Blueprints for American reform will come from studying America's pensions, mutual funds, insurers, boardrooms, and securities markets, not from studying the German or Japanese bank-centered system.

\section{B. Path Dependence and the Futility of Legal Change?}

Nor is it clear that legal change will lead to structural change. Path dependence makes it hard to sort out what the "natural" result is: America suppressed powerful intermediaries, but Germany and Japan not only permitted them, but sometimes encouraged them. During World War II, the Japanese War Ministry required munitions manufacturers to choose a main bank; after German unification in the nineteenth century, the German state encouraged bank power and, perhaps accidentally, pushed custodial stock into the hands of the large banks. While banker stock ownership may well have been ancillary to the encouragement of bank power in both nations, it happened. And conceivably even were regulation in Germany, Japan, and the United States now made to be identical, the path-dependent prevailing structures in each-bank weakness here, and bank power abroad-would continue.

First, the social gains from involvement are probably not large. Other mechanisms substitute, albeit imperfectly, for large shareholders in the boardroom. Second, due to free rider effects, the private gains are even less than the social gains. The institution cannot capture all gains, and the transaction costs of transformation could exceed the private gains to a $5 \%$ stockholder. Third, complex institutions are shaped by their history. For example, American large life insurers were barred from buying any common stock for most of this century. Yet, even with new-found permissions after

206. See, e.g., Saul Hansell, Despite Sharply Different Styles, NCNB, First Union and Wachovia Have Driven Each Other Into the Top Tier of U.S. Banking, INST. INVESTOR, Nov. 1991, at 101 (discussing regional branching of three of America's largest banks).

207. Some of these other institutions, such as pensions, are tied to banks, which sometimes manage pensions. 
1984, they lack the big investments that insurers have in Germany, Japan, and Great Britain.

Britain is another example of path dependence reducing the impact of legal change. It has had a history of partial restrictions: (1) British banking law precluded banks from making long-term investments in the nineteenth century and early twentieth century; ${ }^{208}$ (2) British banks could own stock in the twentieth century, but needed the Bank of England's permission, which until 1980 the Bank would not give; ${ }^{209}$ (3) life insurers faced informal limits, usually precluding ownership of more than $2 \%$ of an industrial firm; ${ }^{210}$ and (4) during Britain's pre-Thatcher socialist era from the 1950's until 1979 investment managers, when taking large and visible positions in industry, had reason to fear nationalization. ${ }^{211}$

Thus, to understand Britain one must discount bankers and insurers due to informal historical constraints (common in England and frustrating to research) and a socialist system (until 1979) that nationalized large enterprises. These partial restrictions have eroded and British ownership of large firms is moderately concentrated. ${ }^{212}$ British institutions, particularly insurers, exercise some voice, although less than the current legal limits would allow, and certainly less than their German and Japanese bank cousins. ${ }^{213}$ The British insurers' greater voice and concentration indicate that restrictions and their history matter; however, the fact that the British institutions have not adopted a German or Japanese structure suggests that their developmental path makes massive structural change difficult, or at least that factors beyond economics, law, and politics, must be added to complete our understanding of corporate structure. Law's historical effect on intermediaries may be less that of a dam that keeps intermediaries and firms apart than that of a blockage that diverts the intermediaries into another path.

208. Tilly, supra note 141 , at $196-98$.

209. Christine M. Cumming \& Lawrence M. Sweet, Financial Structure of the G-10 Countries: How Does the United States Compare?, FED. RESERVE BANK N.Y. Q. REV., Winter 1987-88, at 14, 15; Loretta J. Mester, Banking and Commerce: A Dangerous Liaison?, FED. RESERVE BANK PHIL. BuLl., May/June 1992 , at 17,21 .

210. LAWRENCE D. JONES, INVESTMENT POLICIES OF LIFE INSURANCE COMPANIES 103 n.74 (1968).

211. Cf. HARGREAVES PARKINSON, OWNERSHIP OF INDUSTRY 1-2, 52-53, 102-104 (1951) (examining relationship between ownership structure and risks of industrial nationalization); John Farrar \& Mark Russell, The Impact of Institutional Investment on Company Law, 5 COMPANY LAW. 107, 109, 114 (1984) ("[British i]nstituional investors are worried about the political consequences of an exercise of power. They eschew public criticism and fear public intervention.").

212. Franks \& Mayer, supra note 95 , at tbl. 2 (64\% of the 200 largest British firms have a stockholder owning more than 5\%).

213. Black, supra note 166, at 928 ("British ... insurers, are quite active by American standards."); Getting rid of the boss, ECONOMIST, Feb. 6, 1993, at 13, 13 ("To some extent, British [CEO's] have always had to answer to the tightly knit world of the City of London, whose old-boy networks and customs often served as a check on their worst excesses. But the [CEO's] of big American firms were true masters of all they surveyed."). 


\section{The Paradox of International Competition: Solution and Problem}

Managers are situated in several markets and organizations. The internal organization of the boardroom and its relationship with institutional shareholders is only one. Professional pride of managers and directors makes them try hard even if the organizational constraints acting on them are weak. Embarrassment from media attention will help correct the most egregious errors. Product markets, capital markets, managerial labor markets, employee labor markets, and corporate takeover markets constrain managers. This is all another way of saying that corporate governance is only one dimension of competition.

Until recent decades, large-scale American industry had two critical complementary advantages over much industry abroad: scale economies and competitive structure. The American market was (and is still today) so large that it could support two or three firms, and hence workable competition, at the highest economies of scale in even the heaviest of industries; no other market in the world could do both. Economies of scale in a small nation meant monopoly; competition often meant inefficient scale. America could get both scale and competition; so, if some details in organization at the top and in the boardroom were not for the best, no matter, because scale and competition were so important and might allow for profits that would hide a few defects in organization.

These advantages are no longer exclusively America's. A common market in Europe and a globalized marketplace allow foreign firms scale economies in a competitive market. Details that were once trivial-like corporate governance-become noticed in the 1990's. Stress from international competition reveals weaknesses in some American firms, presses American firms to change, and makes us wonder whether international competition is not just among firms, but also among forms of organization. ${ }^{214}$ The existence, persistence, and until recently, the success, of some rival foreign firms make us question whether the American system is as sound in all dimensions as we have thought.

Competition also partly substitutes for effective corporate governance. Successful foreign firms compete with American firms, pressing badly governed American firms to change or to lose market share. Response to the stimulus of product market competition generally induces American firms to be more productive; corporate governance becomes secondary, relevant only to how (and if) it facilitates change inside the firm.

214. In this sense, international competition mirrors Tiebout's model of state competition as a means of providing efficient regulation. See Charles M. Tiebout, A Pure Theory of Local Expenditures, 64 J. PoL. ECON. 416, 419-20 (1956). 
There is another response that American firms might have to the stimulus of competition, other than to improve. In industries with long-lived capital resources, poorly governed, poorly performing firms may stagger along, as have steel and auto firms, wasting fixed assets without really improving enough. Troubled firms may also respond with political action to reduce competition-lobbying for quotas and tariffs-as have steel and auto firms.

\section{CONCLUSION}

The American-style large firm, with managers at a powerful pinnacle in the hierarchy, is not inevitable. Managers could share authority with intermediaries holding large blocks of stock as they do in Germany and Japan. These foreign differences contradict parts of prevailing corporate theory, which explains key features of the firm as reactions to the principal-agent problems that arise when the firm, to reach economies of scale, sought large inputs of capital from thousands of far-flung investors demanding diversification. As investors became more fragmented, power inside the firm shifted from the shareholders to the managers. While these capital-raising and principal-agent problems are universal, the resulting corporate structures are not; institutional arrangements other than those prevailing in America are possible, and do exist.

There is more than one way to move savings to industry-the American way, via weak intermediaries in a well-developed securities market is only one. Another is via strong intermediaries, like those in Germany and Japan, which not only move funds to firms, but also share power with managers. The strength of financial intermediaries is a product not just of economic evolution, but of history, politics, and culture. As I have argued before, American politics induced laws that fragmented institutions, their portfolios, and their ability to cooperate, precluding the institutional alternative. In Germany and Japan, the ownership structures are different, the corporate structures in which CEO's are embedded are different, the financial institutions are different, and the rules governing financial intermediaries are different. The foreign relationships would be illegal here. We will never know for sure whether American banks would have developed differently without the restraints. We do know that American-style restraints would have been sufficient to stymie banks from foreign-style involvement in corporate governance.

The classical model could be modified in two ways. One would be to scale it back, by conceding that financial rules condition the way corporations grow, so that the American features are the best contractual arrangements available given the restraints. The other way to modify the economic model would be to expand it by arguing that ownership in Germany and Japan will fragment, due to the inevitable economic imperatives of organizing financial intermediaries. Inevitable fragmentation may yet become a true prediction, but it is now only a prediction, not a fact. In Germany, concentrated institutional 
ownership has been increasing, not decreasing, and new alliances that imitate keiretsu relationships belie fragmentation. And Japanese concentrated ownership has been rock-solid for twenty-five years, despite enormous pressure on the banks. Newly-rising, large Japanese firms have adopted the old concentrated ownership, not shunned it.

Political forces in Germany and Japan influence intermediaries and corporate structures, although the forces have been different. Germany's statist policies concentrated banking at the end of the nineteenth century. Later pressures produced codetermination, which is hardly apolitical and created a very different corporate structure than that which prevails in America. Along with German populism, it induces some banker disengagement today. Japanese regulatory politics concentrated Japanese banking, separated banking from securities, and then forced savers and firms to meet in the banking channel. Today, the Japanese system is under stress, but interest group infighting between bankers and brokers stymies full reconstruction of the financial system.

Firms in nations that historically tolerated or encouraged large pools of private economic power evolve differently than do firms in nations that repeatedly fragment financial institutions, their portfolios, and their ability to network blocks of stock. Thus, some of today's incipient fragmentation abroad can be traced to political influences. Moreover, the current economic turmoil in both Germany and Japan makes us wonder whether there will be economic losers associated with the large firm-employees or managers or both-and whether they will appeal to their legislature to re-do the economic result in ways that affect intermediaries and the structure of the large firm, replaying the American political influences that created the American large firm.

Differences do not imply superiority. Labor, regulatory, or cultural differences could explain good performance with the differences in corporate governance spurious. Although corporate differences suggest the importance of asking whether institutional voice can improve firm governance, the evidence of foreign superiority is thus far scant. The inquiry here is by no means the final word; we have only begun to scratch the surface of comparative corporate governance. The direction for the future, I believe, is to understand more than just how different structures could make managers more accountable, but also to see whether institutional voice could address informational defects in securities markets and defects in organization, including industrial organization, labor organization, and the psychology of top-level decisionmaking.

Even if we had more data, the foreign systems would yield no blueprint, because bankers, the protagonists abroad, are not likely to be the key active investors here. Other financial institutions will have to be the source of institutional voice in America, and we cannot get detailed blueprints for them from abroad. While there may be some value to removing the impediments to 
institutional organization, we have little reason to copy the foreign banking systems' details.

This analysis demands a broadening of the corporate academic agenda. Rather than using agency costs or contract theory or judicial doctrine to explain this or that feature as mitigating or reflecting managerial deviation from the maximization of shareholders' wealth, we must consider the role of politics, history, and culture. I lack the deep knowledge of German and Japanese law, corporate structure, history, and politics needed for a definitive interpretation. Although others will have to extend my analysis, the evidence now available casts doubt on the economic model as a full explanation for the Berle-Means corporation. The key lesson is that the prevailing economic model cannot completely explain corporate forms abroad.

Thus, I examine Germany and Japan not to argue that their corporate structures are better and should be mimicked, but to show that different structures are possible; that the American pattern of fragmented shareholders with little power is not inevitable; that managers can share power with intermediaries without making the corporate world fall apart; and that corporate structure is highly sensitive to the organization of financial intermediaries, while the organization of intermediaries is highly sensitive to a nation's politics. 


\section{APPENDIX $^{215}$}

\section{TABLE VIII. Percentage of Stock of Largest German Corporations} Held Directly by German Banks ${ }^{216}$

\begin{tabular}{|c|c|c|}
\hline $\begin{array}{l}\text { Rank and Name } \\
\text { of Company }\end{array}$ & Name of Bank & $\begin{array}{c}\text { Percent of } \\
\text { Outstanding Stock }\end{array}$ \\
\hline \multirow[t]{5}{*}{ 1. Daimler Benz } & Deutsche Bank & 28.20 \\
\hline & Dresdner Bank & 1.60 \\
\hline & Commerzbank & 1.60 \\
\hline & D. Genossen-Bank & 0.30 \\
\hline & Bayerische L-Bank & 1.60 \\
\hline 10. Thyssen AG & Commerzbank & 4.94 \\
\hline 14. BMW & Dresdner Bank & 5.00 \\
\hline 16. Deutsche Lufthansa AG & Bayerische L-Bank & 5.00 \\
\hline 21. M.A.N. AG & Commerzbank & 4.94 \\
\hline \multirow[t]{2}{*}{ 23. Messerschmitt Bölkow-Blohm } & Dresdner Bank & 5.00 \\
\hline & Bayerische V-Bank & 5.00 \\
\hline \multirow[t]{2}{*}{ 25. Karlstadt AG } & Deutsche Bank & $>25.00$ \\
\hline & Commerzbank & $>25.00$ \\
\hline \multirow[t]{2}{*}{ 35. Kaufhof AG (1986) } & Dresdner Bank & 9.00 \\
\hline & Commerzbank & 3.00 \\
\hline 38. Degussa AG & Dresdner Bank & 10.00 \\
\hline \multirow[t]{2}{*}{ 40. Vereinigte Elektrizitäts Westfalen } & Deutsche Bank & 6.30 \\
\hline & Westdeutsche & $>7.20$ \\
\hline \multirow[t]{2}{*}{ 42. Metallgesellschaft AG } & Deutsche Bank & 10.72 \\
\hline & Dresdner Bank & 23.10 \\
\hline 46. Preussag AG & Westdeutsche & 48.80 \\
\hline \multirow[t]{2}{*}{ 57. Linde AG } & Deutsche Bank & 10.00 \\
\hline & Commerzbank & 10.00 \\
\hline 58. Klöckner Werke AG & Deutsche Bank & 19.60 \\
\hline 67. Hochtief AG & Commerzbank & 12.50 \\
\hline 71. Klöckner-Humboldt AG & Deutsche Bank & 41.40 \\
\hline \multirow[t]{2}{*}{ 75. Philipp Holzmann AG } & Deutsche Bank & 35.40 \\
\hline & Commerzbank & 5.00 \\
\hline 90. PWA Papierwerke AG & Bayerische H\&W & 25.00 \\
\hline \multirow[t]{2}{*}{ 92. Bergmann-Elektrizitäts AG } & Deutsche Bank & 36.50 \\
\hline & Bayerische V-Bank & 25.40 \\
\hline
\end{tabular}

Source: DEUTSCHER BUNDESTAG, supra note 16, at 202-06.

215. Tables I-VII are in the text.

216. Largest 100 Companies in 1988. Excludes stock that banks hold through mutual funds or as custodian. 
TABLE IX. Relative Size of German, Japanese, and American Banking Sectors

$$
\begin{aligned}
& \frac{\text { Assets of German Banking Sector }}{\text { German GNP }}=\frac{\$ 1,900 B}{\$ 1,300 B}=146 \% \\
& \frac{\text { Assets of Japanese Banking Sector }}{\text { Japanese GNP }}=\frac{¥ 728,577 B}{¥ 436,927 B}=167 \% \\
& \frac{\text { Assets of American Banking Sector }}{\text { American GNP }}=\frac{\$ 3,399 B}{\$ 5,465 B}=62 \%
\end{aligned}
$$

Source: Monthly ReP. DeUtSChe BundesbanK, Feb. 1991, at 4 (size of German banking system); Memorandum from Bank of Japan to Mark Roe (Aug. 13, 1991) (on file with author) (size of Japanese banking system); FED. RESERVE BANK N.Y. BULL., June 1991, at A18 (size of American banking system).

The German and Japanese banking sectors are about two or three times larger than the American, although the largest German and Japanese banks are approximately five times larger than the largest American banks. The relative weakness of the American banking sector accounts for roughly half of the relatively small size of American banks. 
TABLE X. Relative Size of Largest Bank and Largest Firm in Germany, Japan and America

$$
\begin{aligned}
& \frac{\text { Assets of largest German Bank }}{\text { Assets of largest German Automaker }}=\frac{\$ 267 B}{\$ 49 B}=5.4 \\
& \frac{\text { Assets of largest Japanese Bank }}{\text { Assets of largest Japanese Automaker }}=\frac{¥ 435 B}{¥ 55 B}=7.9 \\
& \frac{\text { Assets of largest American Bank }}{\text { Assets of largest American Automaker }}=\frac{\$ 216 B}{\$ 180 B}=1.2
\end{aligned}
$$

Source: Bank Data from Table V; Automaker Data from WoRLDSCOPE (W/D Partners, ed., 1990), available in NEXIS, Compny library, Wldscp file (Toyota's assets are at June 30, 1990; all others are at December 31, 1990.).

This relationship shows the relative ability of a nation's largest bank to control a large portion of the capitalization of the largest industrial company. We see that American banks are not as able to control large pieces of the largest firms, and there would be concern that the American banks would be poorly diversified if they did. The largest German and Japanese banks, in contrast, are able to control larger pieces of the largest industrial companies without committing as much (as a percentage) of their assets and equity as would be required of an analogous American bank. 


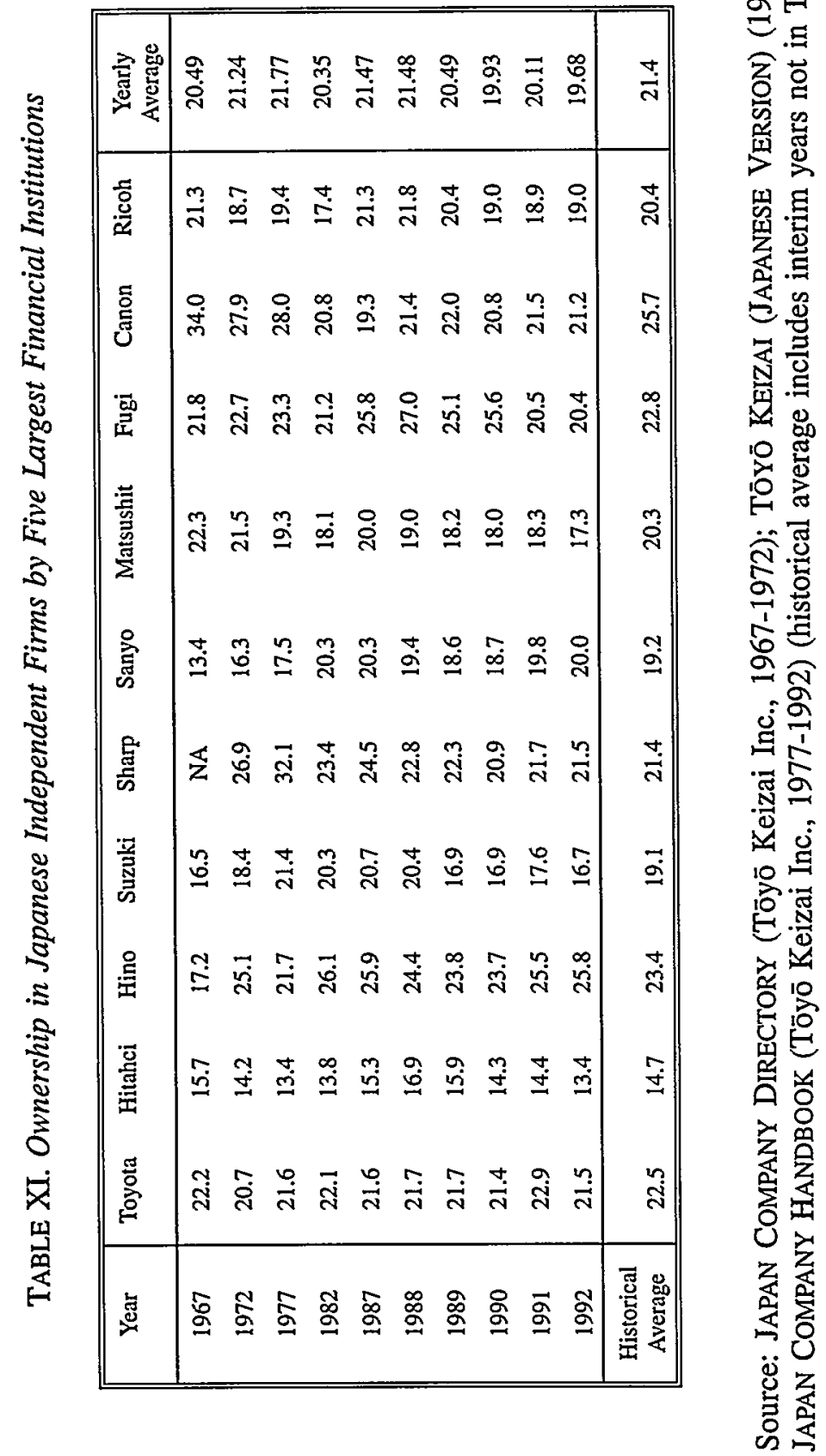




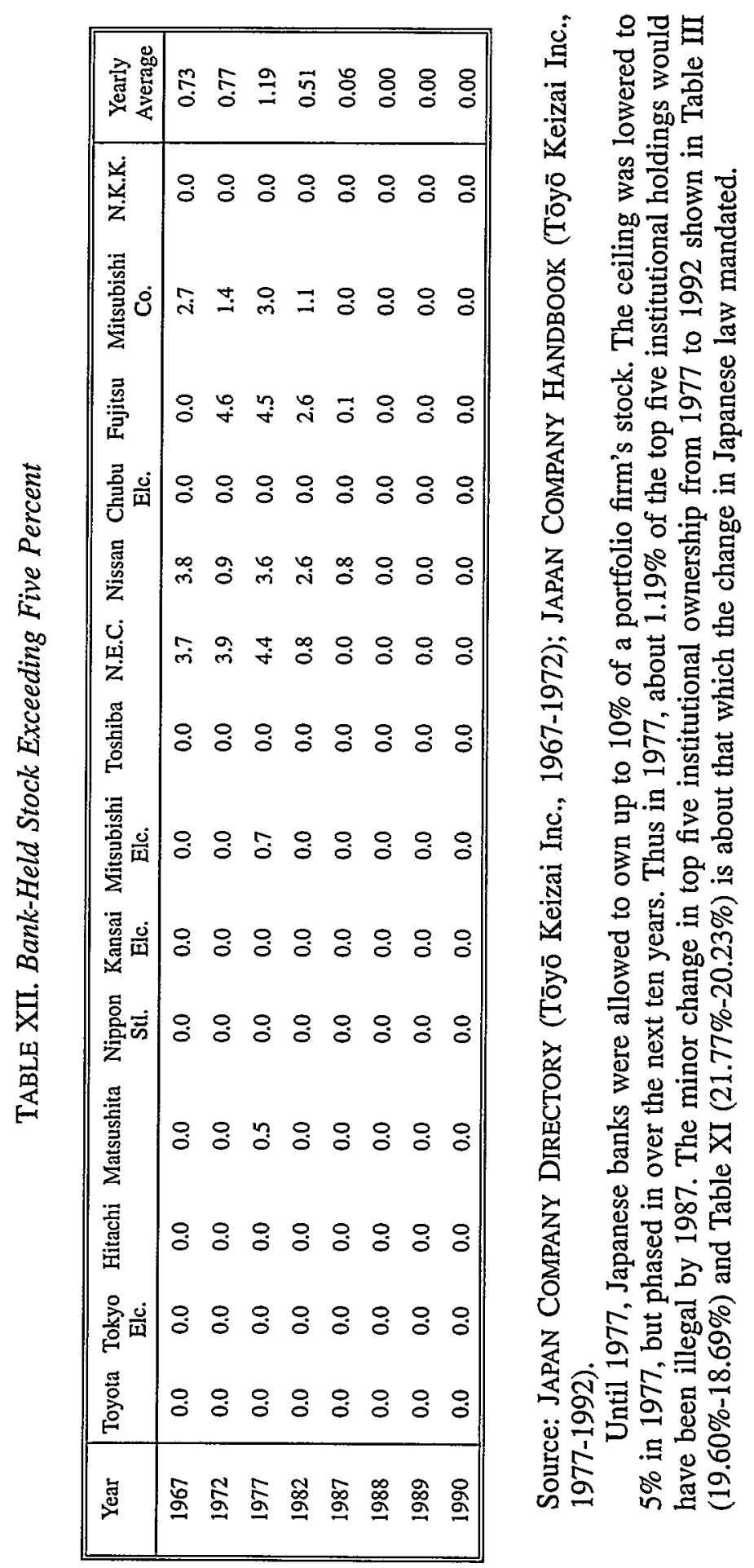


TABLE XIII. Ownership (Voting) Structure for Three Typical American Large Public Firms (1990)

\begin{tabular}{|lc|lc|lc||}
\hline \multicolumn{2}{|c|}{ Exxon } & \multicolumn{2}{c|}{ IBM } & \multicolumn{2}{c|}{ General Electric } \\
\hline \hline $\begin{array}{l}\text { Institutional } \\
\text { Manager }\end{array}$ & $\begin{array}{c}\text { Percent of } \\
\text { Shares }\end{array}$ & $\begin{array}{l}\text { Institutional } \\
\text { Manager }\end{array}$ & $\begin{array}{c}\text { Percent of } \\
\text { Shares }\end{array}$ & $\begin{array}{l}\text { Instutional } \\
\text { Manager }\end{array}$ & $\begin{array}{c}\text { Percent of } \\
\text { Shares }\end{array}$ \\
\hline CREF & 1.09 & Wells Fargo & 1.07 & Wells Fargo & 1.09 \\
Wells Fargo & 1.05 & Mich. St. Treas. & 1.04 & Bankers Trust NY & 1.02 \\
Bankers Trust NY & 1.01 & Bankers Trust NY & 1.01 & CREF & .99 \\
NY St. Common Ret. & .88 & NY St. Common Ret. & .83 & Mellon Bank & .91 \\
Mellon Bank & .73 & Mellon Bank & .76 & NY St. Common Ret. & .88 \\
\hline Top 5 Shareholders & 4.76 & & 4.70 & & 4.89 \\
Top 25 Shareholders & 11.47 & & 13.54 & & 12.89 \\
\hline
\end{tabular}

Source: Brancato et al., supra note 10 . 
